\title{
Tungsten carbide promoted Pd and Pd-Co electrocatalysts for formic acid
} electrooxidation

Yin, Min; Li, Qingfeng; Jensen, Jens Oluf; Huang, Yunjie; Cleemann, Lars Nilausen; Bjerrum, Niels; Xing, Wei

Published in:

Book of abstracts - 3rd CARISMA International Conference on Medium and High Temperature PEM Fuel Cells

Publication date:

2012

Document Version

Publisher's PDF, also known as Version of record

Link back to DTU Orbit

Citation (APA):

Yin, M., Li, Q., Jensen, J. O., Huang, Y., Cleemann, L. N., Bjerrum, N., \& Xing, W. (2012). Tungsten carbide promoted Pd and Pd-Co electrocatalysts for formic acid electrooxidation. In Book of abstracts - 3rd CARISMA International Conference on Medium and High Temperature PEM Fuel Cells (pp. 95-95) http://carisma2012.com

\section{General rights}

Copyright and moral rights for the publications made accessible in the public portal are retained by the authors and/or other copyright owners and it is a condition of accessing publications that users recognise and abide by the legal requirements associated with these rights.

- Users may download and print one copy of any publication from the public portal for the purpose of private study or research.

- You may not further distribute the material or use it for any profit-making activity or commercial gain

- You may freely distribute the URL identifying the publication in the public portal 


\section{CARISMA 2012}

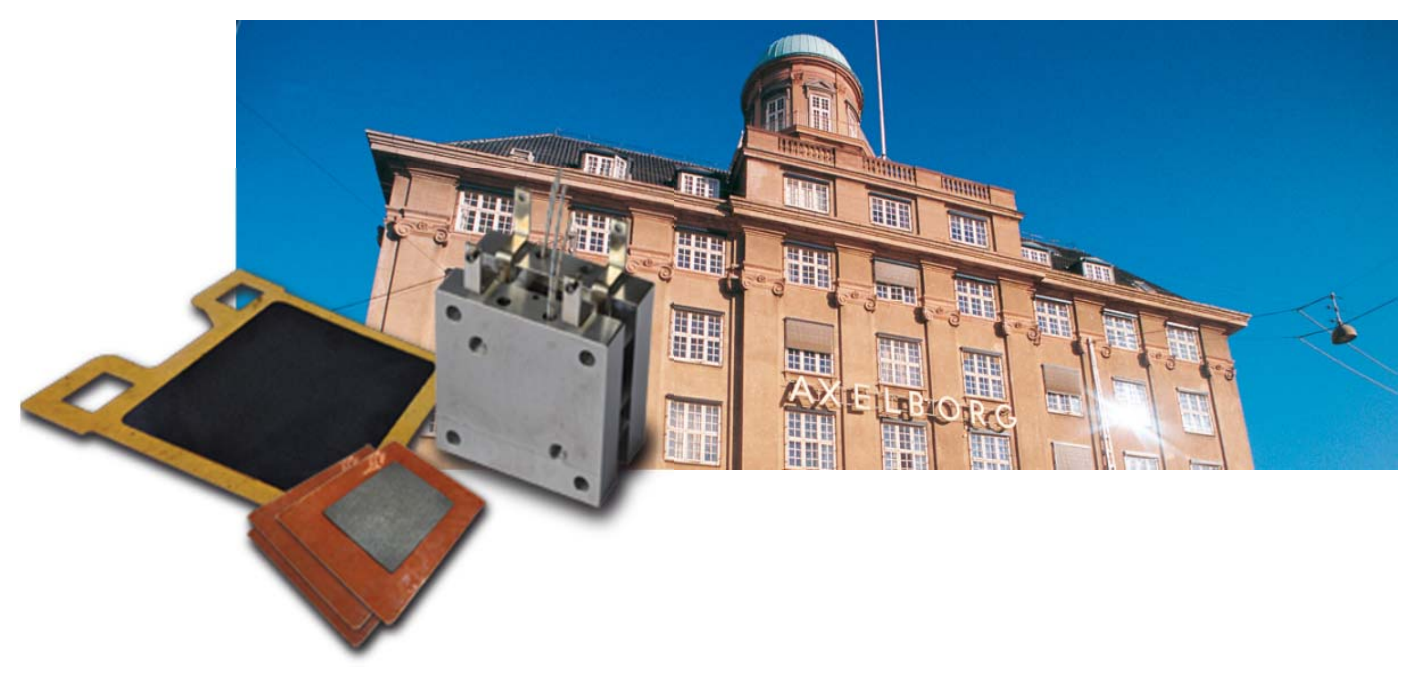

3rd CARISMA International Conference on Medium and High Temperature Proton Exchange Membrane Fuel Cells

$$
3 \text { - } 5 \text { September } 2012
$$

Venue: Axelborg, Copenhagen, Denmark http://carisma2012.com/ 


\section{CARISMA 2012}

\section{3rd CARISMA International Conference on Medium and High Temperature Proton Exchange Membrane Fuel Cells}

3 - 5 September 2012

Venue: Axelborg, Copenhagen, Denmark http://carisma2012.coml

The CARISMA conference series is specifically devoted to the challenges in developing fuel cell materials and membrane electrode assemblies for the medium and high temperature range targeted for transport and stationary applications. The conference will be the opportunity for presentation of recent results, discussion and debate on the solutions sought internationally to the bottlenecks associated with operation at higher temperatures, with an international programme of invited lectures, oral and poster contributions, organized to promote a review of important issues related to materials development and durability for PEMFC systems.

The conference is the third in the series initiated by the CARISMA European Coordination Action on Intermediate and High Temperature Membrane Electrode Assemblies.

Welcome in Copenhagen,

Jens Oluf Jensen

Conference Chair

jojen@dtu.dk

Jens Oluf Jensen

Proton Conductors,

DTU Energy Conversion

Technical University of Denmark

Department of Energy Conversion and Storage

Kemitorvet 207

2800 Kgs. Lyngby, Denmark

www.energi.kemi.dtu.dk 


\section{International Scientific Committee}

Deborah Jones - Université Montpellier 2 (FR)

Brian Benicewicz - University of South Carolina (US)

Andreas Friedrich - DLR Stuttgart (DE)

Hans Aage Hjuler - Danish Power Systems (DK)

Steven Holdcroft - Simon Fraser University, (CA)

Jens Oluf Jensen - Technical University of Denmark (DK)

Klaus-Dieter Kreuer - Max-Planck-Institute for Solid State Research. (DE)

Claude Lamy - Université Montpellier 2 (FR)

Qingfeng Li - Technical University of Denmark (DK)

Justo Lobato - University of Castilla-la Mancha (ES)

James E. McGrath - Virginia Tech. (US)

Jin-Soo Park - Sangmyung University (KR)

Sivakumar Pasupathi - University of the Western Cape (ZA)

Bryan Pivovar - National Renewable Energies Lab. (US)

Bruno G. Pollet - University of the Western Cape (ZA)

Jacques Rozière - Université Montpellier 2 (FR)

Keith Scott - University of Newcastle upon Tyne (UK)

Ulrich Stimming - Technical University of Munich (DE)

Detlef Stolten - Forschungszentrum Jülich (DE)

Masahiro Watanabe - University of Yamanashi (JP)

\section{Local Organizing Committee}

Jens Oluf Jensen - Technical University of Denmark (DK)

Lars Nilausen Cleemann - Technical University of Denmark (DK)

Hans Aage Hjuler - Danish Power Systems (DK)

Qingfeng Li - Technical University of Denmark (DK)

\section{Abstract Book Editor}

Lars Nilausen Cleemann - Technical University of Denmark (DK) 


\section{Programme}

\section{Monday $3^{\text {rd }}$ of September 2012}

\begin{tabular}{|c|c|c|c|}
\hline 08:30 & Registration, Coffee & & \\
\hline Session & Overviews & $\begin{array}{l}\text { Chair: Jens Oluf JENSEN } \\
\text { DTU Energy Conversion (DK) }\end{array}$ & Page \\
\hline 09:00 & Welcome, opening remarks & $\begin{array}{c}\text { Jens Oluf JENSEN } \\
\text { and Søren LINDEROTH } \\
\text { DTU Energy Conversion } \\
\text { Denmark }\end{array}$ & \\
\hline 09:20 & $\begin{array}{l}\text { Overview of PEMFC MEA Component Research } \\
\text { and Development Activities at the DOE Fuel Cell } \\
\text { Technologies Program }\end{array}$ & $\begin{array}{c}\text { Dimitrios PAPAGEORGOPOULOS } \\
\text { (INVITED) } \\
\text { Department of Energy } \\
\text { United States }\end{array}$ & 16 \\
\hline 09:40 & $\begin{array}{l}\text { HTPEMFC Components to Systems - An overview } \\
\text { of Activities at HySA Systems }\end{array}$ & $\begin{array}{c}\text { Sivakumar PASUPATHI } \\
\text { HySA Systems, University of the Western } \\
\text { Cape } \\
\text { South Africa }\end{array}$ & 17 \\
\hline 10:00 & Report on the U.S. DOE HTMWG Progress & $\begin{array}{l}\text { James FENTON } \\
\text { University of Central Florida } \\
\text { United States }\end{array}$ & 18 \\
\hline $10: 20$ & Coffee break & & \\
\hline Session & Catalysts I & $\begin{array}{l}\text { Chair: Robert F. SAVINELL } \\
\text { Case Western Reserve University (US) }\end{array}$ & Page \\
\hline $10: 40$ & $\begin{array}{l}\text { Oxygen Reduction at Non-Precious Metal } \\
\text { Electrocatalysts: Beyond the Standard PEFC } \\
\text { Cathode }\end{array}$ & $\begin{array}{c}\text { Piotr ZELENAY (INVITED) } \\
\text { Los Alamos National Laboratory } \\
\text { Unites States }\end{array}$ & 19 \\
\hline $11: 00$ & $\begin{array}{l}\text { Pt/Pyridine Modified CNTs as electrocatalysts } \\
\text { for High Temperature PEM Fuel Cells }\end{array}$ & $\begin{array}{l}\text { Maria DALETOU } \\
\text { FORTH } \\
\text { Greece }\end{array}$ & 20 \\
\hline $11: 20$ & $\begin{array}{l}\text { A Supportless Approach for Designing a Stable } \\
\text { and Self-Improving Catalyst Architecture for } \\
\text { High Temperature PEM Fuel Cell. }\end{array}$ & $\begin{array}{l}\text { Gustavo DOUBEK } \\
\text { University of São Paulo } \\
\text { Brazil }\end{array}$ & 21 \\
\hline $11: 40$ & $\begin{array}{l}\text { Advanced Catalyst Electrodes with Uniform Pt- } \\
\text { nanowire Arrays for High-Performance Low } \\
\text { Temperature Fuel Cells }\end{array}$ & $\begin{array}{l}\text { Shangfeng DU } \\
\text { University of Birmingham } \\
\text { United Kingdom }\end{array}$ & 22 \\
\hline $12: 00$ & Lunch & & \\
\hline
\end{tabular}




\begin{tabular}{|c|c|c|c|}
\hline \multicolumn{2}{|c|}{ Session 3. Membranes I } & \multirow{2}{*}{$\begin{array}{l}\text { Chair: Sivakumar PASUPATHI } \\
\text { HySA Systems, Uni. Western Cape (ZA) } \\
\text { Brian BENICEWICZ (INVITED) } \\
\text { University of South Carolina } \\
\text { United States }\end{array}$} & \multirow{2}{*}{\begin{tabular}{|r} 
Page \\
23 \\
\end{tabular}} \\
\hline $12: 50$ & PBI Membranes vis the PPA Process & & \\
\hline $13: 10$ & $\begin{array}{l}\text { Physicochemical investigation of phosphoric acid } \\
\text { doped poly( } 2,5 \text {-benzimidazole) as electrolyte } \\
\text { membrane for fuel cells }\end{array}$ & $\begin{array}{l}\text { Anne MAJERUS } \\
\text { Forschungszentrum Jülich } \\
\text { Germany }\end{array}$ & 24 \\
\hline $13: 30$ & $\begin{array}{l}\text { Electrospun Hybrid Membranes an alternative to } \\
\text { Nafion? }\end{array}$ & $\begin{array}{c}\text { Leslie DOS SANTOS } \\
\text { Université Pierre et Marie Curie } \\
\text { France }\end{array}$ & 25 \\
\hline $13: 50$ & \multicolumn{2}{|l|}{ City Hall reception } & \\
\hline \multicolumn{2}{|c|}{ Session 4. MEAs I } & $\begin{array}{l}\text { Chair: Werner LEHNERT } \\
\text { Forschungszentrum Jülich (DE) }\end{array}$ & Page \\
\hline $16: 10$ & $\begin{array}{l}\text { Development of Durable High Temperature } \\
\text { PEMFC MEA }\end{array}$ & $\begin{array}{l}\text { Jung Ock PARK (INVITED) } \\
\text { Samsung Electronics } \\
\text { South Korea }\end{array}$ & 26 \\
\hline $16: 30$ & $\begin{array}{l}\text { Performance and degradation of high } \\
\text { Performance MEAs For High Temperature PBI } \\
\text { Fuel Cells }\end{array}$ & $\begin{array}{l}\text { Thomas STEENBERG } \\
\text { Danish Power Systems } \\
\text { Denmark }\end{array}$ & 27 \\
\hline $16: 50$ & $\begin{array}{l}\text { Development of mid temperature PEM } \\
\text { membranes, catalysts and MEAs in the frame of } \\
\text { the MT-PEMFC-Cluster project }\end{array}$ & $\begin{array}{l}\text { Volker PEINECKE } \\
\text { ZBT } \\
\text { Germany }\end{array}$ & 28 \\
\hline $17: 10$ & $\begin{array}{l}\text { HT-PEM Fuel Cell: Compression Analysis by } \\
\text { Electrochemical Characterization and Micro- } \\
\text { Computed Tomography }\end{array}$ & $\begin{array}{l}\text { Anja DIEDRICHS } \\
\text { NEXT ENERGY - EWE } \\
\text { Germany }\end{array}$ & 29 \\
\hline $17: 30$ & \multicolumn{2}{|l|}{ Coffee break } & \\
\hline \multicolumn{2}{|c|}{ Session 5. Alkaline cells } & $\begin{array}{l}\text { Chair: Young-Woo CHOI } \\
\text { Korea Institute of Energy Research (KR) }\end{array}$ & Page \\
\hline $17: 50$ & $\begin{array}{l}\text { Latest advances in Alkaline Membrane Fuel Cell } \\
\text { (AMFC) technology }\end{array}$ & $\begin{array}{l}\text { Dario DEKEL } \\
\text { CellEra } \\
\text { Israel }\end{array}$ & 30 \\
\hline 18:10 & $\begin{array}{l}\text { Polyethylene based anionic exchange } \\
\text { membranes for solid alkaline fuel cells (SAFC) }\end{array}$ & $\begin{array}{c}\text { Syed Tauqir Ali SHERAZI } \\
\text { COMSATS Institute of Information } \\
\text { Technology } \\
\text { Pakistan }\end{array}$ & 31 \\
\hline $18: 30$ & $\begin{array}{l}\text { Aromatic block copolymers as anion exchange } \\
\text { membranes }\end{array}$ & $\begin{array}{l}\text { Kenji MIYATAKE } \\
\text { University of Yamanashi } \\
\text { Japan }\end{array}$ & 32 \\
\hline 18:50 & Poster session (odd numbers) + Buffet & $\begin{array}{l}\text { 20:00-21:00 Committee Meeting } \\
\text { Room: Axel } 4\end{array}$ & \\
\hline $20: 50$ & End & & \\
\hline
\end{tabular}




\section{Tuesday $4^{\text {th }}$ of September 2012}

\begin{tabular}{|c|c|c|c|}
\hline \multirow{2}{*}{$\begin{array}{l}08: 30 \\
09: 00\end{array}$} & \multicolumn{2}{|l|}{ Registration, Coffee } & \\
\hline & Announcements & & \\
\hline \multicolumn{2}{|c|}{ Session 6. Membranes II } & $\begin{array}{l}\text { Chair: Jacques ROZIÈRE } \\
\text { Université Montpellier } 2 \text { (FR) }\end{array}$ & Page \\
\hline 09:10 & $\begin{array}{l}\text { Approaches to the mechanical stabilisation of } \\
\text { highly functionalised membranes for medium } \\
\text { and high temperature PEMFC }\end{array}$ & $\begin{array}{l}\text { Deborah JONES (INVITED) } \\
\text { Université Montpellier } 2 \\
\text { France }\end{array}$ & 33 \\
\hline 09:30 & $\begin{array}{l}\text { Proton Conducting Phase-Separated Multiblock } \\
\text { Copolymers with Sulfonated Poly(Phenylene } \\
\text { Sulfone) Blocks for Electrochemical Applications: } \\
\text { Preparation, Morphology, Hydration, } \\
\text { Mechanical Properties and Transport }\end{array}$ & $\begin{array}{l}\text { Klaus-Dieter KREUER } \\
\text { Max-Planck-Institut für } \\
\text { Festkörperforschung } \\
\text { Germany }\end{array}$ & 34 \\
\hline $09: 50$ & $\begin{array}{l}\text { Proton Conducting Hydrophilic-Hydrophobic } \\
\text { Multiblock Copolymers with Highly Sulfonated } \\
\text { and Hydrolytically Stable Blocks }\end{array}$ & $\begin{array}{l}\text { Shogo TAKAMUKU } \\
\text { Lund University } \\
\text { Sweden }\end{array}$ & 35 \\
\hline $10: 10$ & $\begin{array}{l}\text { Recent Development of Acid Doped } \\
\text { Polybenzimidazole Membranes in Denmark - } \\
\text { Polymer Chemistry and Durability Issues }\end{array}$ & $\begin{array}{c}\text { Qingfeng LI } \\
\text { Technical University of Denmark } \\
\text { Denmark }\end{array}$ & 36 \\
\hline $10: 30$ & \multicolumn{2}{|l|}{ Coffee break } & \\
\hline \multicolumn{2}{|c|}{ Session 7. Catalysts II } & $\begin{array}{l}\text { Chair: Piotr ZELENAY } \\
\text { Los Alamos National Laboratory (US) }\end{array}$ & Page \\
\hline $10: 50$ & $\begin{array}{l}\text { Phosphorus-doped ordered mesoporous carbon: } \\
\text { effect of size on electrocatalytic activity towards } \\
\text { oxygen reduction }\end{array}$ & $\begin{array}{l}\text { Jong-sung YU } \\
\text { Korea University } \\
\text { South Korea }\end{array}$ & 37 \\
\hline $11: 10$ & $\begin{array}{l}\text { A new concept for noble metal-free cathode } \\
\text { catalysts based on metalorganic Fe and Co } \\
\text { compounds in ordered mesoporous carbon }\end{array}$ & $\begin{array}{c}\text { Johanna K. DOMBROVSKIS } \\
\text { Chalmers University of Technology } \\
\text { Sweden }\end{array}$ & 38 \\
\hline $11: 30$ & $\begin{array}{l}\text { New approaches for the characterization of } \\
\text { porous electrodes devoted to oxygen reduction }\end{array}$ & $\begin{array}{l}\text { Henri PEREZ } \\
\text { CEA } \\
\text { France }\end{array}$ & 39 \\
\hline $11: 50$ & $\begin{array}{l}\text { Electrocatalytic activity and stability of antimony } \\
\text { doped tin oxide supported platinum catalyst for } \\
\text { PEM fuel cells }\end{array}$ & $\begin{array}{c}\text { Magnus THOMASSEN } \\
\text { SINTEF } \\
\text { Norway }\end{array}$ & 40 \\
\hline $12: 10$ & Lunch & & \\
\hline
\end{tabular}




\begin{tabular}{|c|c|c|c|}
\hline \multicolumn{2}{|c|}{ Session 8. Electrodes } & $\begin{array}{l}\text { Chair: Thomas J. SCHMIDT } \\
\text { Paul Scherrer Institut (CH) }\end{array}$ & Page \\
\hline $13: 10$ & $\begin{array}{l}\text { Carbon Nanotube/PBI Composites as a Material } \\
\text { for the Future PEMFC Electrocatalyst }\end{array}$ & $\begin{array}{c}\text { Naotoshi NAKASHIMA (INVITED) } \\
\text { Kyushu University } \\
\text { Japan }\end{array}$ & 41 \\
\hline $13: 30$ & $\begin{array}{l}\text { Novel Electrocatalyst Support Materials for High } \\
\text { Temperature PEMFC }\end{array}$ & $\begin{array}{l}\text { Amrit CHANDAN } \\
\text { University of Birmingham } \\
\text { United Kingdom }\end{array}$ & 42 \\
\hline $13: 50$ & $\begin{array}{l}\text { Evaluation of crack structures in catalyst layers } \\
\text { of dynamically operated HT-PEFCs from in situ } \\
\text { synchrotron X-ray radiographs }\end{array}$ & $\begin{array}{l}\text { Wiebke MAIER } \\
\text { Forschungszentrum Jülich } \\
\text { Germany }\end{array}$ & 43 \\
\hline $14: 10$ & $\begin{array}{l}\text { Self-supporting Microporous Layers (MPLs) for } \\
\text { PEM fuel cells }\end{array}$ & $\begin{array}{l}\text { Alexander BAUDER } \\
\text { DLR } \\
\text { Germany }\end{array}$ & 44 \\
\hline $14: 30$ & & \\
\hline \multicolumn{2}{|c|}{ Session 9. MEAs II } & $\begin{array}{l}\text { Chair: Jung Ock PARK } \\
\text { Samsung Electronics (KR) }\end{array}$ & Page \\
\hline $14: 50$ & $\begin{array}{l}\text { Mobility and distribution of phosphoric acid in } \\
\text { high-temperature polymer electrolyte fuel cells }\end{array}$ & $\begin{array}{l}\text { Werner LEHNERT (INVITED) } \\
\text { Forschungszentrum Jülich } \\
\text { Germany }\end{array}$ & 45 \\
\hline $15: 10$ & $\begin{array}{l}\text { Comparative experimental study of the } \\
\text { performance of two different types of high } \\
\text { temperature polymer electrolyte membrane } \\
\text { electrode assemblies }\end{array}$ & $\begin{array}{l}\text { Søren Juhl ANDREASEN } \\
\text { Aalborg University } \\
\text { Denmark }\end{array}$ & 46 \\
\hline $15: 30$ & $\begin{array}{l}\text { Platinum Pulse Plating on aligned MWCNTs for } \\
\text { PEMFC }\end{array}$ & $\begin{array}{l}\text { Mathias WEISER } \\
\text { TU Dresden } \\
\text { Germany }\end{array}$ & 47 \\
\hline $15: 50$ & Poster session (even numbers) & & \\
\hline $17: 50$ & Walk to harbour & & \\
\hline $18: 20$ & Harbour boat tour & & \\
\hline $19: 20$ & Conference Dinner at Copenhagen Opera House & & \\
\hline $22: 50$ & Return & & \\
\hline
\end{tabular}




\section{Wednesday $5^{\text {th }}$ of September 2012}

\begin{tabular}{|c|c|c|c|}
\hline 09:00 & Registration, Coffee & & \\
\hline 09:30 & Announcements & & \\
\hline Session & 0. Four Sesons & $\begin{array}{l}\text { Chair: Niels J. Bjerrum } \\
\text { DTU Energy Conversion (DK) }\end{array}$ & Page \\
\hline 09:40 & $\begin{array}{l}\text { Modeling of Ultrathin Catalyst Layers in Polymer } \\
\text { Electrolyte Fuel Cells }\end{array}$ & $\begin{array}{l}\text { Karen CHAN } \\
\text { Simon Fraser University } \\
\text { Canada }\end{array}$ & 48 \\
\hline 10:00 & $\begin{array}{l}\text { Innovative plasma polymerized membranes based on } \\
\text { phosphonic acid groups for fuel cell }\end{array}$ & $\begin{array}{l}\text { Joelle BASSIL } \\
\text { Université Montpellier } 2 \\
\text { France }\end{array}$ & 49 \\
\hline $10: 20$ & $\begin{array}{l}\text { Glass flake templated composite PFSA membranes } \\
\text { with nanoparticulate inorganic additives and a } \\
\text { hierarchical structure }\end{array}$ & $\begin{array}{l}\text { Bhawana AGRAWAL } \\
\text { University of Bayreuth } \\
\text { Germany }\end{array}$ & 50 \\
\hline $10: 40$ & $\begin{array}{l}\text { Water Electrolysis using Polymeric Electrolyte } \\
\text { Membranes at Elevated Temperatures }\end{array}$ & $\begin{array}{l}\text { Erik CHRISTENSEN } \\
\text { DTU Energy Conversion } \\
\text { Denmark }\end{array}$ & 51 \\
\hline 11:00 & Coffee break & & \\
\hline Session & 1.Systems and Stacks & $\begin{array}{l}\text { Chair: Deborah JONES } \\
\text { Université Montpellier } 2 \text { (FR) }\end{array}$ & Page \\
\hline $11: 20$ & HTPEM System benefits and challenges & $\begin{array}{l}\text { Frank ERNE (INVITED) } \\
\text { Elcomax } \\
\text { Germany }\end{array}$ & 52 \\
\hline $11: 40$ & $\begin{array}{l}\text { High temperature PEM fuel cell activities at Aalborg } \\
\text { University }\end{array}$ & $\begin{array}{l}\text { Søren Knudsen KAER (INVITED) } \\
\text { Aalborg University } \\
\text { Denmark }\end{array}$ & 53 \\
\hline $12: 00$ & $\begin{array}{l}\text { EnerFuel High Temperature PEM (HTPEM) Fuel Cell } \\
\text { Stacks and System }\end{array}$ & $\begin{array}{l}\text { Tom PAVLIK } \\
\text { EnerFuel } \\
\text { United States }\end{array}$ & 54 \\
\hline $12: 20$ & Fuel Cell Stacks for HT- and LT-PEM Systems & $\begin{array}{l}\text { Steen YDE-ANDERSEN } \\
\text { IRD Fuel Cells } \\
\text { Denmark }\end{array}$ & 55 \\
\hline $12: 40$ & Lunch & & \\
\hline
\end{tabular}




\begin{tabular}{|c|c|c|c|}
\hline \multicolumn{2}{|c|}{ Session 12. Degradation } & \multirow{2}{*}{$\begin{array}{l}\text { Chair: Qingfeng LI } \\
\text { DTU Energy Conversion (DK) } \\
\text { Thomas J. SCHMIDT (INVITED) } \\
\text { Paul Scherrer Institut } \\
\text { Switzerland }\end{array}$} & \multirow{2}{*}{$\begin{array}{l}\text { Page } \\
56 \\
56\end{array}$} \\
\hline $13: 40$ & $\begin{array}{l}\text { Advanced Degradation Studies of High Temperature } \\
\text { PEFCs }\end{array}$ & & \\
\hline 14:00 & $\begin{array}{l}\text { Detection of MEA's flaws in PEMFC: "in-situ" } \\
\text { Relaxometry combined with "ex-situ" Infrared } \\
\text { Imagery }\end{array}$ & $\begin{array}{l}\text { Gilles DE MOOR } \\
\text { LEPMI-LMOPS CNRS } \\
\text { France }\end{array}$ & 57 \\
\hline $14: 20$ & $\begin{array}{l}\text { Numerical Simulation of the Electrolyte }\left(\mathrm{H}_{3} \mathrm{PO}_{4}\right) \text { Loss } \\
\text { in HT-PEM Fuel Cells }\end{array}$ & $\begin{array}{c}\text { Sebastian LANG } \\
\text { University of Technology Darmstadt } \\
\text { Germany }\end{array}$ & 58 \\
\hline $14: 40$ & $\begin{array}{l}\text { Theory of lonomer Aggregation in Polymer } \\
\text { Electrolyte Membranes }\end{array}$ & $\begin{array}{l}\text { Pierre-Éric MELCHY } \\
\text { Simon Fraser University } \\
\text { Canada }\end{array}$ & 59 \\
\hline $15: 00$ & $\begin{array}{l}\text { Evaluation of Platinum Band Formation in PEM Fuel } \\
\text { Cells }\end{array}$ & $\begin{array}{l}\text { Marianne RODGERS } \\
\text { University of Central Florida } \\
\text { United States }\end{array}$ & 60 \\
\hline $15: 20$ & \multicolumn{2}{|l|}{ Coffee break } & \\
\hline \multicolumn{2}{|c|}{ Session 13. Membranes III } & $\begin{array}{l}\text { Chair: Klaus-Dieter KREUER } \\
\text { Max-Planck-Inst. für } \\
\text { Festkörperforschung (DE) }\end{array}$ & Page \\
\hline $15: 40$ & $\begin{array}{l}\text { Recent research of the PBI/PA system as a proton } \\
\text { conductor in electrochemical systems }\end{array}$ & $\begin{array}{c}\text { Robert F. SAVINELL (INVITED) } \\
\text { Case Western Reserve University } \\
\text { United States }\end{array}$ & 61 \\
\hline $16: 00$ & Nano-structured Aromatic lonomers for PEMFC & $\begin{array}{l}\text { Cristina IOJOIU } \\
\text { Universite de Savoie } \\
\text { France }\end{array}$ & 62 \\
\hline $16: 20$ & $\begin{array}{l}\text { A simply synthesized procedure of sulfonated } \\
\text { poly(arlyene ether) type polymers for polymer } \\
\text { electrolyte membrane fuel cells }\end{array}$ & $\begin{array}{c}\text { Young-woo CHOI } \\
\text { Korea Institute of Energy Research } \\
\text { South Korea }\end{array}$ & 63 \\
\hline $16: 40$ & $\begin{array}{l}\text { Aromatic Polyethers for High Temperature Polymer } \\
\text { Electrolyte Membrane Fuel Cells (HT-PEMFCs) } \\
\text { operating above } 180^{\circ} \mathrm{C}\end{array}$ & $\begin{array}{c}\text { Aikaterini ANDREOPOULOU } \\
\text { FORTH/ICE-HT } \\
\text { Greece }\end{array}$ & 64 \\
\hline $17: 00$ & $\begin{array}{l}\text { Kinetic Study on the Doping Level of ABPBI } \\
\text { Membrane }\end{array}$ & $\begin{array}{l}\text { Fang LIU } \\
\text { Forschungszentrum Jülich } \\
\text { Germany }\end{array}$ & 65 \\
\hline $17: 20$ & Closing & $\begin{array}{l}\text { Jens Oluf Jensen } \\
\text { DTU Energy Conversion } \\
\text { Denmark }\end{array}$ & \\
\hline
\end{tabular}




\section{Posters}

\begin{tabular}{|c|c|c|c|}
\hline No. & Membranes & & Page \\
\hline 51 & $\begin{array}{l}\text { Performance of a phosphonated hydrocarbon } \\
\text { ionomer in the fuel cell cathode catalyst layer }\end{array}$ & $\begin{array}{l}\text { Rakel WRELAND LINDSTRöM } \\
\text { KTH - Royal Institute of Technology } \\
\text { Sweden }\end{array}$ & 66 \\
\hline 52 & $\begin{array}{l}\text { Temperature Dependence of the States of Water } \\
\text { Clusters and Proton Conductivity for Perfluorinated } \\
\text { and Hydrocarbon Ionomers for Fuel Cells }\end{array}$ & $\begin{array}{l}\text { M. A. BARIQUE } \\
\text { Fuel Cell Cutting-Edge Research } \\
\text { Center } \\
\text { Japan }\end{array}$ & 67 \\
\hline 53 & $\begin{array}{l}\text { How Water Uptake and Temperature Affects Proton } \\
\text { Conductivity of Poly(vinylidene fluoride-co- } \\
\text { chlorotrifluoroethylene)-g-poly(styrene sulfonic acid) } \\
\text { and Its Blends with PVDF }\end{array}$ & $\begin{array}{l}\text { Mads Møller NIELSEN } \\
\text { DTU Chemical Engineering } \\
\text { Denmark }\end{array}$ & 68 \\
\hline 54 & $\begin{array}{l}\text { Locally confined membrane modification preventing } \\
\text { edge-break and gas inlet/outlet area degradation } \\
\text { during fuel cell operation }\end{array}$ & $\begin{array}{c}\text { Dirk HENKENSMEIER } \\
\text { Korea Institute of Science and } \\
\text { Technology } \\
\text { South Korea }\end{array}$ & 69 \\
\hline 55 & $\begin{array}{l}\text { Proton Exchange Membranes Reinforced by } \\
\text { Impregnation with Hydrocarbon Polymer Electrolyte } \\
\text { for PEM Fuel Cells }\end{array}$ & $\begin{array}{l}\text { Nayoung KIM } \\
\text { Kolon Central Research Park } \\
\text { South Korea }\end{array}$ & 70 \\
\hline 56 & $\begin{array}{l}\text { A Study on Heteropolyacid-Sulfonated Hydrocarbon- } \\
\text { based hybrid Membrane }\end{array}$ & $\begin{array}{c}\text { Akihiro OHIRA } \\
\text { National Institute of Advanced } \\
\text { Industrial Science and Technology } \\
\text { (AIST) } \\
\text { Japan }\end{array}$ & 71 \\
\hline 57 & $\begin{array}{l}\text { Statistical copoly(biaryl thioether sulfone)s and } \\
\text { copoly(biaryl sulfone)s with di- and tetrasulfonated } \\
\text { units as proton conducting membranes }\end{array}$ & $\begin{array}{l}\text { Annika WEIBER } \\
\text { Lund University } \\
\quad \text { Sweden }\end{array}$ & 72 \\
\hline 58 & $\begin{array}{l}\text { Comparative study of the properties and degradation } \\
\text { of sulfonated poly(arylene ether sulfone)s with the } \\
\text { same polymer backbone but with different positions } \\
\text { of the acid groups }\end{array}$ & $\begin{array}{l}\text { Shogo TAKAMUKU } \\
\text { Lund University } \\
\text { Sweden }\end{array}$ & 73 \\
\hline 59 & $\begin{array}{l}\text { Influence of Side Groups on the Properties of } \\
\text { Aromatic Polymer Electrolyte Membranes for High } \\
\text { Temperature-PEMFCs }\end{array}$ & $\begin{array}{c}\text { Christina MORFOPOULOU } \\
\text { FORTH/ICE-HT } \\
\text { Greece }\end{array}$ & 74 \\
\hline
\end{tabular}




\begin{tabular}{|c|c|c|c|}
\hline 60 & $\begin{array}{l}\text { Fabrication and characterization of proton } \\
\text { conducting composite materials for electrolytes in } \\
\text { intermediate temperature fuel cells and water } \\
\text { electrolysers }\end{array}$ & $\begin{array}{l}\text { Annemette Hindhede JENSEN } \\
\text { DTU Energy Conversion } \\
\text { Denmark }\end{array}$ & 75 \\
\hline 61 & $\begin{array}{l}\text { Cross-linked high acid doping level } \\
\text { polybenzimidazole membranes with high } \\
\text { conductivity and improved mechanical properties }\end{array}$ & $\begin{array}{l}\text { Aurelien KREISZ } \\
\text { Univ. Montpellier } 2 \\
\text { France }\end{array}$ & 76 \\
\hline 62 & $\begin{array}{l}\text { Niobium Phosphates as Intermediate Temperature } \\
\text { Proton Conductor }\end{array}$ & $\begin{array}{l}\text { Yunjie HUANG } \\
\text { DTU Energy Conversion } \\
\text { Denmark }\end{array}$ & 77 \\
\hline 63 & $\begin{array}{l}\text { Anion conducting polymer membranes for hydrogen } \\
\text { production through alkaline water electrolysis }\end{array}$ & $\begin{array}{l}\text { David AlLI } \\
\text { DTU Energy Conversion } \\
\text { Denmark }\end{array}$ & 78 \\
\hline 64 & $\begin{array}{l}\text { Antimony Doped Tin Oxides and Their Composites } \\
\text { with Tin pyrophosphates as Catalyst Supports for } \\
\text { Oxygen Evolution Reaction in Proton Exchange } \\
\text { Membrane Water Electrolysis }\end{array}$ & $\begin{array}{l}\text { Qingfeng LI } \\
\text { DTU Energy Conversion } \\
\text { Denmark }\end{array}$ & 79 \\
\hline 65 & 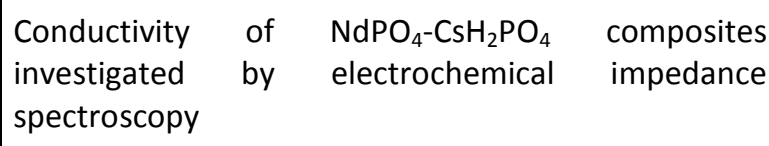 & $\begin{array}{l}\text { Tatiana ANFIMOVA } \\
\text { DTU Energy Conversion } \\
\text { Denmark }\end{array}$ & 80 \\
\hline 66 & $\begin{array}{l}\text { Pendant-sulfonated poly(arylene ether ketone) } \\
\text { (PAEK) membranes cross-linked with a proton } \\
\text { conducting reagent for fuel cells }\end{array}$ & $\begin{array}{l}\text { Dukjoon KIM } \\
\text { Sungkyunkwan University } \\
\text { South Korea }\end{array}$ & 81 \\
\hline 67 & $\begin{array}{l}\text { Inorganic-organic membranes from the short side } \\
\text { chain perfluorosulfonic acid ionomer for direct } \\
\text { methanol fuel cells }\end{array}$ & $\begin{array}{c}\text { Kristina ANGELI } \\
\text { CNRS - Univ. Montpellier \& Univ. } \\
\text { Calabria } \\
\text { France }\end{array}$ & 82 \\
\hline 68 & $\begin{array}{l}\text { Ionic liquid functionalized mesoporous silica-Nafion } \\
\text { nanocomposite membranes for PEMFC application }\end{array}$ & $\begin{array}{l}\text { Joong Hee LEE } \\
\text { Chonbuk National University } \\
\text { South Korea }\end{array}$ & 83 \\
\hline
\end{tabular}

Gonzalez DANIEL

Tecnalia

Spain 


\begin{tabular}{|c|c|c|c|}
\hline 70 & $\begin{array}{l}\text { Synthesis and Electrochemical Testing of Pt-Cr Alloys } \\
\text { as Cathode Catalyst for Proton Exchange Membrane } \\
\text { Fuel Cells }\end{array}$ & $\begin{array}{l}\text { Gaurav GUPTA } \\
\text { University of Birmingham } \\
\text { United Kingdom }\end{array}$ & 85 \\
\hline 71 & $\begin{array}{l}\text { Platinum-Cobalt Catalysts for the Oxygen Reduction } \\
\text { Reaction in HT PEMFCs }\end{array}$ & $\begin{array}{l}\text { Alexander SCHENK } \\
\text { Graz University of Technology } \\
\text { Austria }\end{array}$ & 86 \\
\hline 72 & $\begin{array}{l}\text { Ordered multimodal porous carbon as an efficient } \\
\text { catalyst support in proton exchange membrane fuel } \\
\text { cell }\end{array}$ & $\begin{array}{l}\text { Jong-sung YU } \\
\text { Korea University } \\
\text { South Korea }\end{array}$ & 87 \\
\hline 73 & $\begin{array}{l}\text { Pt based PEMFC catalysts from colloidal particle } \\
\text { suspensions - a toolbox for model studies }\end{array}$ & $\begin{array}{l}\text { Jozsef SPEDERUniversity of } \\
\text { CopenhagenDenmark }\end{array}$ & 88 \\
\hline 74 & $\begin{array}{l}\text { Effects of heat treatments in the performance of } \\
\text { bimetallic } \mathrm{Pt}_{3} \mathrm{Mo}_{2} / \mathrm{C} \text { catalysts as co tolerant anodes } \\
\text { on proton-exchange membrane fuel cells }\end{array}$ & $\begin{array}{l}\text { Ayaz HASSAN } \\
\text { Sao Carlos USP } \\
\text { Brazil }\end{array}$ & 89 \\
\hline 75 & Alternative supports for PEM Fuel Cell Catalysts & $\begin{array}{l}\text { Alessandro ZANA } \\
\text { University of Copenhagen } \\
\text { Denmark }\end{array}$ & 90 \\
\hline 76 & $\begin{array}{l}\text { Effect of Se modification of } \mathrm{Ru}_{3} \mathrm{Se}_{\mathrm{y}} / \mathrm{C} \text { electrocatalysts } \\
\text { on the oxygen reduction activities in the presence of } \\
\text { phosphoric acid }\end{array}$ & $\begin{array}{c}\text { Jong Hyun JANG/Hee-young PARK } \\
\text { Korea Institute of Science and } \\
\text { Technology (KIST) } \\
\text { South Korea }\end{array}$ & 91 \\
\hline 77 & $\begin{array}{l}\text { Synthesis dependent composition and } \\
\text { electrocatalytic properties of } \mathrm{Pt}_{\mathrm{x}} \mathrm{Co}_{1-\mathrm{x}} \text { alloys. }\end{array}$ & $\begin{array}{l}\text { Ioannis SPANOS } \\
\text { University of Copenhagen } \\
\text { Denmark }\end{array}$ & 92 \\
\hline 78 & $\begin{array}{l}\text { Poly(benzimidazole)-functionalized graphene as a } \\
\text { stable and durable support for PEM fuel cell } \\
\text { electrocatalysts }\end{array}$ & $\begin{array}{l}\text { Anastasia A. PERMYAKOVA } \\
\text { DTU Energy Conversion } \\
\text { Denmark }\end{array}$ & 93 \\
\hline 79 & $\begin{array}{l}\text { A Pt-free catalyst based on Fe-N-C composites for } \\
\text { oxygen reduction reaction (ORR) }\end{array}$ & $\begin{array}{c}\text { Abdouelilah HACHIMI } \\
\text { Center of Nanotechnology (CENT) \& } \\
\text { Department of Chemistry, KFUPM } \\
\text { Saudi Arabia }\end{array}$ & 94 \\
\hline 80 & $\begin{array}{l}\text { Tungsten carbide promoted } \mathrm{Pd} \text { and } \mathrm{Pd}-\mathrm{Co} \\
\text { electrocatalysts for formic acid electrooxidation }\end{array}$ & $\begin{array}{l}\text { Yunjie HUANG } \\
\text { DTU Energy Conversion } \\
\text { Denmark }\end{array}$ & 95 \\
\hline 81 & $\begin{array}{l}\text { Efficient electrocatalytic oxygen reduction over self- } \\
\text { supported polyaniline-based non-precious metal } \\
\text { catalyst }\end{array}$ & $\begin{array}{l}\text { Yang HU } \\
\text { Changchun Institute of Applied } \\
\text { Chemistry } \\
\text { China }\end{array}$ & 96 \\
\hline
\end{tabular}


$3^{\text {rd }}$ CARISMA International Conference

on Medium and High Temperature PEM Fuel Cells

Copenhagen, 3 - 5 September 2012

\begin{tabular}{|c|l|c|c|}
\hline 82 & $\begin{array}{l}\text { Transition metal carbides as electrode materials for } \\
\text { HT PEM systems }\end{array}$ & $\begin{array}{c}\text { Antonio Luis TOMAS GARCIA } \\
\text { DTU Energy Conversion } \\
\text { Denmark }\end{array}$ & 97 \\
\hline 83 & $\begin{array}{l}\mathrm{Pt}_{5} \mathrm{Gd} \text { as a highly active and stable catalyst for } \\
\text { oxygen electroreduction }\end{array}$ & $\begin{array}{l}\text { Maria ESCUDERO ESCRIBANO } \\
\text { DTU Physics } \\
\text { Denmark }\end{array}$ & 98 \\
\hline
\end{tabular}

\section{No. MEAs and Electrodes}

\begin{tabular}{|c|c|c|c|}
\hline 84 & $\begin{array}{l}\text { Determining HTPEM electrode parameters using a } \\
\text { mechanistic impedance model }\end{array}$ & $\begin{array}{l}\text { Jakob Rabjerg VANG } \\
\text { Aalborg University } \\
\text { Denmark }\end{array}$ & 99 \\
\hline 85 & $\begin{array}{l}\text { Titanium PBI composite membranes for high } \\
\text { temperature PEMFC. From a } 5 \mathrm{~cm}^{2} \text { single cell to a } \\
150 \mathrm{~cm}^{2} \text { short stack }\end{array}$ & $\begin{array}{c}\text { Hector R. GARCíA } \\
\text { University of Castilla-La Mancha } \\
\text { Spain }\end{array}$ & 100 \\
\hline 86 & $\begin{array}{l}\text { Polymer Selection and Catalyst Ink Preparation for a } \\
\text { Membrane Electrode Assembly in a Thermally } \\
\text { Regenerative Fuel Cell }\end{array}$ & $\begin{array}{l}\text { Mark SKERRITT } \\
\text { Queen's University } \\
\text { Canada }\end{array}$ & 101 \\
\hline 87 & $\begin{array}{l}\text { Development of MEAs based on electrophoretic } \\
\text { deposition for high temperature PEMFC applications }\end{array}$ & $\begin{array}{c}\text { Cecil FELIX } \\
\text { HySA Systems, Univ. of the Western } \\
\text { Cape } \\
\text { South Africa }\end{array}$ & 102 \\
\hline 88 & Pt-loading into a PEM Surface in a Drying Process & $\begin{array}{l}\text { Jae-young LEE/Hong-ki LEE } \\
\text { Woosuk University } \\
\text { South Korea }\end{array}$ & 103 \\
\hline 89 & $\begin{array}{l}\text { Analysis of kinetic and diffusion losses in large area } \\
\text { HT PEMFCs }\end{array}$ & $\begin{array}{c}\text { George BANDLAMUDI } \\
\text { ZBT } \\
\text { Germany }\end{array}$ & 104 \\
\hline 90 & $\begin{array}{l}\text { Direct dimethyl ether high temperature polymer } \\
\text { electrolyte membrane fuel cells with improved } \\
\text { performance }\end{array}$ & $\begin{array}{l}\text { Anton VASSILIEV } \\
\text { DTU Energy Conversion } \\
\text { Denmark }\end{array}$ & 105 \\
\hline 91 & $\begin{array}{l}\text { Catalyst coated polybenzimidazole-membrane based } \\
\text { assemblies for high temperature PEMFC }\end{array}$ & $\begin{array}{l}\text { Nicolas SEPHANE } \\
\text { Univ. Montpellier } 2 \\
\text { France }\end{array}$ & 106 \\
\hline 92 & $\begin{array}{l}\text { High Temperature Polymer Electrolyte Membrane } \\
\text { Fuel Cells - Performance and degradation }\end{array}$ & $\begin{array}{l}\text { Thomas STEENBERG } \\
\text { Danish Power Systems } \\
\text { Denmark }\end{array}$ & 107 \\
\hline 93 & $\begin{array}{l}\text { Effect of humidity on HT-PEM fuel cell manufacture } \\
\text { in all steps from PBI synthesis to MEA storage }\end{array}$ & $\begin{array}{l}\text { Carina TERKELSEN } \\
\text { Danish Power Systems } \\
\text { Denmark }\end{array}$ & 108 \\
\hline
\end{tabular}




\begin{tabular}{|c|l|c|c|}
\hline 94 & $\begin{array}{l}\text { Energy Dispersive X-ray Analysis used to quantify the } \\
\text { Phosphoric Acid Doping Level in Polybenzimidazole } \\
\text { based Fuel Cells }\end{array}$ & $\begin{array}{c}\text { Thorsten HOLST } \\
\text { Danish Power Systems } \\
\text { Denmark }\end{array}$ & 109 \\
\hline 95 & $\begin{array}{l}\text { Low Energy X-ray Imaging used to quantify the Large- } \\
\text { Area Thickness Variation of the Catalyst Loading on } \\
\text { Carbon Cloth based Electrodes for Fuel Cells }\end{array}$ & $\begin{array}{c}\text { Thorsten HOLST } \\
\text { Danish Power Systems } \\
\text { Denmark }\end{array}$ & 110 \\
\hline 96 & $\begin{array}{l}\text { Semi-empirical modeling in a proton exchange } \\
\text { membrane fuel cell system - Membrane Electrode } \\
\text { Assembly (MEA to MEA) variation }\end{array}$ & $\begin{array}{c}\text { Hector RODRIGO GARCíA } \\
\text { Danish Power Systems } \\
\text { Denmark }\end{array}$ & 111 \\
\hline 98 & $\begin{array}{l}\text { In-depth understanding of cathode mechanisms and } \\
\text { catalyst support role in the polymer electrolyte fuel } \\
\text { cells (PEMFCs) } \\
\text { Electrospun Nanofibres As Novel Support Materials } \\
\text { For PEMFC Electrodes }\end{array}$ & $\begin{array}{c}\text { Center of Nanotechnology (CENT) \& } \\
\text { Department of Chemistry, KFUPM } \\
\text { Saudi Arabia }\end{array}$ & 112 \\
\hline
\end{tabular}

\begin{tabular}{|c|c|c|c|}
\hline No. & Degradation & & Page \\
\hline 99 & $\begin{array}{l}\text { Comparison of Proton Exchange Membranes } \\
\text { Degradation Rates Between Accelerated and } \\
\text { Performance Tests }\end{array}$ & $\begin{array}{c}\text { Marianne RODGERS } \\
\text { University of Central Florida } \\
\text { United States }\end{array}$ & 114 \\
\hline 100 & $\begin{array}{l}\text { Effect of Membrane Equivalent Weight on } \\
\text { Degradation Under Accelerated Stress Conditions }\end{array}$ & $\begin{array}{c}\text { Marianne RODGERS } \\
\text { University of Central Florida } \\
\text { United States }\end{array}$ & 115 \\
\hline 101 & $\begin{array}{l}\text { In situ and ex situ monitoring of the mitigation of } \\
\text { membrane degradation by radical scavengers and } \\
\text { hydrogen peroxide decomposition catalysts }\end{array}$ & $\begin{array}{l}\text { Marta ZATON } \\
\text { CNRS-Univ. Montpellier } 2 \\
\text { France }\end{array}$ & 116 \\
\hline 102 & $\begin{array}{l}\text { Application of TGA Techniques to Analyze the MEA } \\
\text { Degradation }\end{array}$ & $\begin{array}{c}\text { Jong Hyun JANG } \\
\text { Korea Institute of Science and } \\
\text { Technology (KIST) } \\
\text { South Korea }\end{array}$ & 117 \\
\hline 103 & $\begin{array}{l}\text { Quantification of ionomer in solution by } 19 F \text { NMR in } \\
\text { order to follow organic phase degradation in active } \\
\text { layers }\end{array}$ & $\begin{array}{l}\text { Assma EL KADDOURI } \\
\text { LEPMI - LMOPS } \\
\text { France }\end{array}$ & 118 \\
\hline 104 & $\begin{array}{l}\text { Fuel Cell Catalyst degradation mechanisms - a study } \\
\text { on size-selected Platinum nanoclusters }\end{array}$ & $\begin{array}{l}\text { M. RöEFZAAD } \\
\text { University of Copenhagen } \\
\text { Denmark }\end{array}$ & 119 \\
\hline
\end{tabular}




\begin{tabular}{|c|l|c|c|}
\hline 105 & $\begin{array}{l}\text { Corrosion behaviour of construction materials for } \\
\text { high temperature water electrolysers }\end{array}$ & $\begin{array}{c}\text { Aleksey NIKIFOROV } \\
\text { DTU Energy Conversion } \\
\text { Denmark }\end{array}$ & 120 \\
\hline 106 & $\begin{array}{l}\text { Corrosion behavior of construction materials for } \\
\text { intermediate temperature steam electrolysers }\end{array}$ & $\begin{array}{c}\text { Aleksey NIKIFOROV } \\
\text { DTU Energy Conversion } \\
\text { Denmark }\end{array}$ & 121 \\
\hline
\end{tabular}

\section{No. Alkaline cells}

107 Electrocatalysis of Oxygen Reduction on PlatinumFree Cathode Catalysts for Alkaline Membrane Fuel

Kaido TAMMEVESKI Cells

No. Systems and Reforming Estonia

\begin{tabular}{|c|c|c|c|}
\hline No. & Systems and Reforming & & Page \\
\hline 108 & $\begin{array}{l}\text { Hydrogen Production from Methanol for High } \\
\text { Temperature PEM Fuel Cells using a Catalytic } \\
\text { Reformer }\end{array}$ & $\begin{array}{c}\text { Jakob ENGBAEK } \\
\text { Danish Technological Institute } \\
\text { Denmark }\end{array}$ & 123 \\
\hline 109 & $\begin{array}{l}\text { Control of a methanol reformer system using an } \\
\text { adaptive neuro-fuzzy inference system approach }\end{array}$ & $\begin{array}{l}\text { Søren Juhl ANDREASEN } \\
\text { Aalborg University } \\
\text { Denmark }\end{array}$ & 124 \\
\hline 110 & $\begin{array}{l}\text { On The Use of Phosphoric Acid-Doped } \\
\text { Polybenzimidazole as a Membrane in a Thermally } \\
\text { Regenerative Fuel Cell }\end{array}$ & $\begin{array}{l}\text { Todd ALLWARD } \\
\text { Queens University } \\
\text { Canada }\end{array}$ & 125 \\
\hline 111 & $\begin{array}{l}\text { Optimal control of PEMFC system based on Genetic } \\
\text { Algorithm }\end{array}$ & $\begin{array}{l}\text { Sarika TYAGI } \\
\text { Abengoa } \\
\text { Spain }\end{array}$ & 126 \\
\hline 112 & $\begin{array}{l}\text { Development of a 100We ATR-WGS Integrated } \\
\text { Ethanol Fuel Processor for High Temperature PEMFC } \\
\text { Applications }\end{array}$ & $\begin{array}{c}\text { Hyoung-juhn KIM } \\
\text { Korea Institute of Science and } \\
\text { Technology (KIST) } \\
\text { South Korea }\end{array}$ & 127 \\
\hline 113 & Fuel Cells for Portable Electronics & $\begin{array}{c}\text { Peter Brilner LUND } \\
\text { Danish Technological Institute } \\
\text { Denmark }\end{array}$ & 128 \\
\hline
\end{tabular}




\section{Overview of PEMFC MEA Component Research and Development Activities at the DOE Fuel Cell Technologies Program}

Dimitrios Papageorgopoulos ${ }^{\mathrm{a}}$,

${ }^{a}$ U.S. Department of Energy (dimitrios.papageorgopoulos@ee.doe.gov),

The U.S. Department of Energy's Fuel Cell Technologies Program supports research and development (R\&D) of fuel cells and fuel cell systems, with a primary focus on reducing cost and improving durability, to allow fuel cells to compete in the marketplace. The presentation will provide an overview of activities, highlighting recent progress, with particular emphasis on membrane electrode assembly (MEA) component R\&D for polymer electrolyte membrane fuel cells (PEMFCs). Reducing precious group metal (PGM) content in MEAs is a key path to decreasing PEMFC system cost. De-alloyed catalysts, produced through chemical or electrochemical leaching of surface non-noble components from PGM/base metal alloys, have demonstrated promise as candidate materials for cathode catalysts. These catalysts consist of a core rich in base metal, encapsulated by a protective shell of PGM. De-alloyed PtNi nanoparticle catalysts have demonstrated mass activity exceeding the DOE target of $0.44 \mathrm{~A} / \mathrm{mgPGM}$ at $0.9 \mathrm{~V}$, and have met the project milestone for performance at high current of $0.56 \mathrm{~V}$ at $1.5 \mathrm{~A} / \mathrm{cm}^{2}$. Similar PtNi catalysts are being developed in continuous nanostructured thin-film (NSTF) format, demonstrating achievement of the mass activity target, while yielding voltage higher than $0.6 \mathrm{~V}$ at $1.5 \mathrm{~A} / \mathrm{cm}^{2}$. Core-shell catalysts have also been developed based on deposition of Pt monolayer shells on pre-formed Pt-free or low-Pt cores. This catalyst technology, along with innovative synthesis techniques, was recently licensed by a major catalyst manufacturer. Modified catalysts capable of withstanding the destructive conditions of start-up, shutdown, and cell reversal have been demonstrated using low levels of IrRu oxygen evolution catalyst. NSTF catalysts modified with IrRu have exceeded 5000 simulated start-up/shutdown cycles, and more than 200 cell reversals $(0.2$ $\mathrm{A} / \mathrm{cm}^{2}$ ), while meeting performance durability targets, all at a PGM loading of only 0.135 $\mathrm{mg} / \mathrm{cm}^{2}$. Development of high-conductivity perfluorinated ionomers with low swelling, using multi-acid side chain polymers with perfluoro imide and sulfonic acid proton donors, has resulted in membranes capable of meeting nearly all DOE targets; even under the hottest and driest conditions targeted $\left(120^{\circ} \mathrm{C}, 40 \mathrm{kPa} \mathrm{H} \mathrm{H}_{2} \mathrm{O}\right.$ vapor) these membranes have area specific resistance within $15 \%$ of the 2017 target value, and are capable of meeting all other DOE membrane performance and durability targets under cooler and wetter conditions. 


\title{
2 - Oral presentation
}

\section{HTPEMFC Components to Systems - An overview of Activities at HySA Systems}

\author{
Sivakumar Pasupathi ${ }^{\mathrm{a}}$, Cecil Felix ${ }^{\mathrm{g}}$, Olivia Barron ${ }^{\mathrm{h}}$, Piotr Bujlo ${ }^{\mathrm{i}}$, Huaneng Su${ }^{\mathrm{j}}$, Bruno Pollet ${ }^{\mathrm{k}}$, \\ ${ }^{a}$ HySA Systems (spasupathi@uwc.ac.za), ${ }^{9}$ HySA Systems, ${ }^{\text {h}}$ HySA Systems, ${ }^{1}$ HySA Systems, ${ }^{j}$ HySA Systems, ${ }^{k} H y S A$ \\ Systems,
}

HySA Systems is a Center of Competence for Technology Validation and Systems Integration on hydrogen and fuel cell technology (HFCT), located at the South African Institute for Advanced Materials Chemistry (SAIAMC), University of the Western Cape (UWC). HySA Systems is part of a long-term (15-year) Hydrogen and Fuel Cell Technologies (HFCT) Research, Development, and Innovation (RDI) strategy, which officially was launched in September 2008 by the Department of Science and Technology (DST) in South Africa. One of the focus areas of HySA systems is the development of high temperature PEMFC components and systems, particularly for combined heat and power applications. The RD\&D activities include the development and optimization of membrane electrode assemblies, development of stacks and systems. The presentation will provide an overview of these activities. 


\section{3 - Oral presentation}

\section{Report on the U.S. DOE HTMWG Progress}

James M. Fenton $^{\mathrm{a}}$, R. Paul Brooker ${ }^{\mathrm{b}}$, Marianne Rodgers ${ }^{\mathrm{g}}$, Nahid Mohajeri ${ }^{\mathrm{h}}$, Darlene Slattery ${ }^{\mathrm{i}}$, Leonard J. Bonville ${ }^{j}, H$. Russell Kunz ${ }^{k}$,

a University of Central Florida (jmatley@mail.ucf.edu), ${ }^{b}$ University of Central Florida, ${ }^{9}$ University of Central Florida,

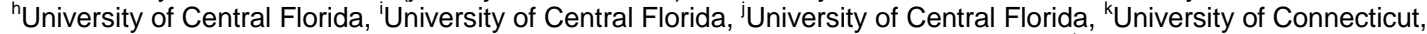
'University of Central Florida,

The Florida Solar Energy Center (FSEC) has led the U.S. Department of Energy (DOE) High Temperature Membrane Working Group (HTMWG since 2006. The HTMWG investigates membrane performance at elevated temperature/low relative humidity conditions. For the final three years of the project, FSEC has worked with six teams to develop membrane electrode assembly (MEA) fabrication methods for their respective membranes. This presentation details the challenges associated with MEA fabrication of various membrane types, along with the performance results from several HTMWG membranes. The MEA fabrication technique utilized by FSEC is to suspend the membrane vertically in front of a heated plate, and then spray catalyst-ink slurry onto the membrane. Following electrode application, the CCM is hot pressed to ensure good interfacial contact. Through these procedures, several challenges were identified. First, during electrode application, the membrane can swell due to the high solvent content in the ink and the heat from the plate. These combined effects were shown to cause significant internal stresses in a hydrocarbon-based membrane with Teflon support. A second challenge was the ductility (either too high or low) of the membrane, leading to poor mechanical stability. Too high ductility rendered spraying ineffective, while too low ductility led to crack formation, either during spraying or hot pressing. An example is given of a membrane showing a series of pressure-induced cracks after hot pressing. A third challenge relates to the compatibility of the ionomer in the electrode vs. that in the membrane. For the majority of the teams, the same ionomer was utilized in the electrode, in order to provide consistency across the tests. However, due to differences in the membrane, the cell performance changed, even though the electrodes were the same. Notwithstanding these challenges, several cells showed significant progress towards DOE performance and durability targets, including a hydrocarbon-based membrane. One team was able to develop a membrane that exhibited several times-lower fluoride release than NRE 211. Another team's fuel cell performance exceeded DOE targets, with further optimization possible. These results will be presented. 


\title{
4 - Invited Oral presentation
}

\section{Oxygen Reduction at Non-Precious Metal Electrocatalysts: Beyond the Standard PEFC Cathode}

\author{
Piotr Zelenay ${ }^{\mathrm{a}}$, Hoon Chung ${ }^{\mathrm{g}}$, Qing $\mathrm{Li}^{\mathrm{h}}{ }^{\mathrm{h}}$, Gang Wu ${ }^{\mathrm{i}}$, \\ a Los Alamos National Laboratory (zelenay@lanl.gov), ${ }^{9}$ Los Alamos National Laboratory, ${ }^{\text {h}}$ Los Alamos National \\ Laboratory, 'Los Alamos National Laboratory,
}

\begin{abstract}
With a growing awareness that the use of platinum needs to be either greatly reduced or completely eliminated from the polymer electrolyte fuel cell (PEFC), non-precious metal catalysts (NPMCs) for oxygen reduction reaction (ORR) have received lots of attention in recent years as a possible replacement of $\mathrm{Pt}$ and its alloys at the fuel cell cathode. In addition to promising a major cost advantage for PEFCs, NPMC catalyst of oxygen reduction offer several potential advantages thanks to their unique properties, both in acid alkaline fuel cells. Alkaline fuel cells. While at present the stability of non-precious metal electrocatalysts is not yet sufficient for the implementation in practical PEFCs, the use of NPMCs at the alkaline fuel cell cathode appears far more likely thanks to high activity and very good stability of the catalysts at high $\mathrm{pH}$ values. Together, the activity and stability improvements account for 40 $50 \mathrm{mV}$ RDE performance advantage of several tested NPMCs over Pt-based state-of-the-art catalysts in alkaline solutions, a gap that tends to increase even further at longer operating times of the electrochemical cell. Advanced nanostructures. In an attempt to further improve the activity and high-current response of non-precious catalysts in both PEFC and alkaline fuel cell cathodes, nitrogen-doped carbon nanotubes (N-CNTs) have recently been synthesized at LANL using a new, simple, and scalable fabrication method for newgeneration, active, and durable non-PGM catalysts of oxygen reduction. $\mathrm{N}$-doping endows CNTs with n-type metallic conductivity and enhances toughness. It also creates defects in the graphene stacking in CNTs that appear to be correlated to the ORR activity. Anion tolerance. Due to severe poisoning by chemisorbed phosphate ions ORR activity of Pt cathode catalysts is significantly reduced in fuel cells that use phosphoric acid as an electrolyte. In this study, we will demonstrate NPMCs with high tolerance to phosphate chemisorption, high activity and good cycling stability in the phosphoric acid electrolyte compared to Pt catalysts. These catalysts show high promise in reducing cathode losses in phosphoric acid fuel cells, as well as in high-temperature fuel cells operating with polybenzimidazole (PBI) membranes doped with phosphoric acid. Potential application of non-precious-metal oxygen reduction catalysts in metal-air batteries will also be discussed in the presentation.
\end{abstract}




\title{
5 - Oral presentation
}

\section{Pt/Pyridine Modified CNTs as electrocatalysts for High Temperature PEM Fuel Cells}

\author{
Maria Daletou $^{\mathrm{a}}$, Aline Orfanidi ${ }^{\mathrm{g}}$, Joannis Kallitsis ${ }^{\mathrm{h}}$, Stylianos Neophytides ${ }^{\mathrm{i}}$,
}

anstitute of Chemical Engineering Sciences, FORTH/ICE-HT, Patras 26504, Greece (riadal@iceht.forth.gr), ${ }^{9}$ Institute of Chemical Engineering Sciences, FORTH/ICE-HT, Patras 26504, Greece, "Department of Chemistry, University of Patras, 26500 Patras, Greece, 'Institute of Chemical Engineering Sciences, FORTH/ICE-HT, Patras 26504, Greece,

A novel approach towards the development of Pt electrocatalysts supported on carbon nanotubes, CNTs, with increased catalyst utilization for use in high temperature PEM fuel cells is reported. Toward the development of an optimized electrocatalytic system, there are two important considerations; depositing fine Pt particles on the carbon support and bringing them into the three-phase region. In this work, CNTs were surface modified introducing pyridine based groups on the side walls. The aim was to homogeneously disperse pyridine moieties throughout the electrocatalytic layer, which are known to interact with phosphoric acid, in order to create an ionic conductive pathway and increase the electrochemical interface[1]. The functionalization of the carbon nanotubes was verified by the use of XPS, Raman and TGA. Thereafter, Pt was introduced by the use of a modified polyol synthesis and the catalysts were characterized by means of XRD, TEM and $\mathrm{H}_{2}$ chemisorption, proving the fine distribution of deposited $\mathrm{Pt}$ nanoparticles on the modified support with minimal aggregation, narrow size distribution and nanoparticles around 2-3nm[1]. In order to investigate the resistance to sintering under the operating temperatures of a fuel cell, a series of in-situ XRD measurements took place incorporating the new catalysts as well as the commercial $\mathrm{Pt} / \mathrm{C}$ for comparison reasons. Moreover, the synthesized electrocatalysts were investigated as anodic electrodes in a HT PEMFC. The electrolyte was based on a $\mathrm{H}_{3} \mathrm{PO}_{4}$ impregnated ADVENT TPS ${ }^{\circledR}$ polymer membrane[2]. Electrochemical measurements included steady state potentiostatic fuel cell experiments, galvanostatic AC impedance measurements and $\mathrm{CO}$ strip potentiodynamic measurements for the determination of the electrochemical surface area (ECSA). The measurements were focused on the performance and anode degradation operating under various compositions of reformate $\mathrm{H}_{2}$ at $180^{\circ} \mathrm{C}$. References

1 A. Orfanidi et al, Appl. Catal. B: Environ. 106, 2011, 379

2 M.K. Daletou et.al. Modern Aspects of Electrochemistry, No 49, p.301, Springer, New York, 2010; E.K. Pefkianakis et al, Macromol. Rapid Commun. 26, 2005, 1724; M.Geormezi et al, Macromolecules 41, 2008, 9051

Acknowledgments Financial support from the European Commission through the program "Understanding the Degradation Mechanisms of Membrane-Electrode-Assembly for High Temperature PEMFCs and Optimization of the Individual Components" DEMMEA FCHJU 245156 (2010-2012) is greatly acknowledged. 


\title{
6 - Oral presentation
}

\section{A Supportless Approach for Designing a Stable and Self- Improving Catalyst Architecture for High Temperature PEM Fuel Cell.}

\author{
Gustavo Doubek ${ }^{\mathrm{a}}$, Ryan Sekol ${ }^{\mathrm{g}}$, Marcelo Linardi ${ }^{\mathrm{h}}$, Sundeep Mukherjee ${ }^{\mathrm{i}}$, Jan Schroers ${ }^{\mathrm{j}}$, André Taylor $^{\mathrm{k}}$, \\ a University of São Paulo; Yale University (doubeksi@gmail.com), ${ }^{g}$ Yale University, ${ }^{\text {h} U n i v e r s i t y ~ o f ~ S a ̃ o ~ P a u l o, ~ ' Y a l e ~}$ \\ University, 'Yale University, ${ }^{\text {K}}$ Yale University,
}

\section{Summary}

We suggest a supportless approach for the catalyst by using porous platinum metallic glass nanorods and platinum nanotubes, which yields to a high specific catalytic activity and notorious stability.

Noble metal nanoparticles supported on carbon have greatly contributed with the development of the PEM fuel cell technology and currently compose the state of the art catalyst, but its fragility, especially in higher operational temperatures, cannot be overlooked. Nanoparticles tend to naturally agglomerate and carbon support suffers from corrosion what leads to a loss on the electrochemical active surface area (ECSA) and the catalyst performance with it. For this reason an adjustment over how the catalyst is designed is needed in order to develop a system with satisfactory physical-chemical properties, associated with the required stability at the fuel cell environment. We suggest a supportless approach for the catalyst by tailoring noble-metal disposition at the catalytic layer. This was accomplished either by designing platinum nanotubes (PtNT) and porous Pt based metallic glass nanowires (PtMG). Both architectures, due to its dimensions, are ought to provide a high specific active surface area and have the potential to prevent secondary agglomeration processes, thus increasing fuel cell's life time. Pure platinum nanotubes were fabricated by galvanic displacement with silver nanowires in a single pot reaction. The natural driving force reduced the noble metal at the silver surface, and at the same time dissolved the silver core. The synthesized tubes presented an average of $200 \mathrm{~nm}$ of diameter with only 2-5 nm in wall thickness. Platinum based metallic glass were termoplastically molded into nanowires followed by the fabrication of an interconnected nanoporous structure created into the surface through selective dealloying. Both structures were confirmed by HR-TEM. Both catalysts where tested over their stability by means of an electrochemical cycling procedure for a total of 2000 cycles at $80^{\circ} \mathrm{C}$ in phosphoric acid media. The PtNT displayed $40 \%$ less loss over the ECSA when compared to the commercially available Pt/C Etek, and the PtMG catalyst did not only showed no loss from the initial active surface area but actually demonstrated an ongoing improvement over time due to further dealloying. This was due to the spinodal decomposition, that creates a self-improving catalyst owing to etching at the solid-electrolyte interface. EDX made at HAADF mode also showed noble metal enrichment at the porous structure. 


\title{
7 - Oral presentation
}

\section{Advanced Catalyst Electrodes with Uniform Pt-nanowire Arrays for High-Performance Low Temperature Fuel Cells}

\author{
Shangfeng Du ${ }^{a}$, Kejie Lin ${ }^{g}$, Hanshan Dong ${ }^{\text {h }}$, \\ ${ }^{a}$ School of Chemical Engineering, University of Birmingham, Birmingham B15 2TT, UK (s.du@bham.ac.uk), ${ }^{9}$ School \\ of Metallurgy and Materials, University of Birmingham, Birmingham B15 2TT, UK, " $S c h o o l$ of Metallurgy and \\ Materials, University of Birmingham, Birmingham B15 2TT, UK,
}

One-dimensional features of Pt nanowires can overcome some drawbacks of nanoclusters which suffer from the 'particle size effect' and aggregate readily leading to reduced mass activity and efficiency as electrocatalysts in low temperature fuel cells [1]. Some research has showed that Pt-based nanowires exhibited a better catalytic capability than supported or unsupported Pt nanoparticles as electrocatalysts in fuel cells, especially under the high catalyst loading that is typically required for direct methanol fuel cells (DMFCs) [2]. Using formic acid as a reducing agent, single-crystal Pt nanowires along the $<111>$ direction can be prepared from precursor at room temperature, without using any templates, organic solvents or inducing growth catalysts [1]. With gas diffusion layer (GDL) as a direct support, single-crystal Pt nanowires, with a length ca. 50-200 nm, were in-situ grown onto GDL surfaces and used directly as integrated gas diffusion electrodes (GDEs) in low temperature fuel cells [3]. This route is much simpler than the conventional method for preparing GDEs because no processes are needed to make the ink or print the catalysis layer. Membrane electrode assemblies (MEAs) with as-prepared GDEs were manufactured and tested in $16 \mathrm{~cm} 2$ PEMFC or $5 \mathrm{~cm} 2$ DMFC hardware in comparison with commercial electrodes. Cyclic voltammetry (CV) analysis, electrochemical impedance spectroscopy (EIS) and polarization measurements were performed to full cells and electrodes to evaluate the as-prepared GDEs. The results showed that, even with a lower electrochemical surface area (ECSA) than did the commercial products, the Pt-nanowire GDE possessed a higher catalytic performance and a better durability [2-4]. By introducing an active-screen plasma treatment approach, the superhydrophobic behavior of the GDL surface can be modified to enable the growth of much uniform Pt-nanowire arrays in GDE [5]. In this case, the catalytic performance of the prepared GDEs can be improved by $7 \%$ or more. The simple process and the high performance make this approach a promising method to be used for fabricating gas diffusion electrodes in fuel cell applications.

\section{References:}

[1] S Sun, G Zhang, D Geng, et al. Angew Chem Int Ed 2011;50:422 - 426.

[2] S Du. Int. J. Low-Carbon Tech. 2012:7: 44-54

[3] S Du. J Power Sources 2010:195:289-292.

[4] S Du and A Majewski. European Fuel Cell Forum Proceeding (2011) A0707 [5] S Du and H Dong. Gas Diffusion Electrodes. GB1203409.6. 


\title{
8 - Invited Oral presentation
}

\section{PBI Membranes vis the PPA Process}

\author{
Brian Benicewicz ${ }^{a}$, \\ aUniversity of South Carolina (benice@sc.edu),
}

\section{Summary}

PBI membranes produced from a sol-gel PPA process exhibit high conductivities and long term durability. Newer efforts are focused on further improving the mechanical properties at high temperature.

There have been major efforts for more than a decade to increase the operating temperature of polymer based membrane fuel cells above the traditional operating temperature of approximately $85^{\circ} \mathrm{C}$. Polybenzimidazole (PBI) polymers are excellent candidates for PEM fuel cell membranes capable of operating at temperatures up to $200^{\circ} \mathrm{C}$. One of the more important benefits of $\mathrm{PBI}$ polymers doped with phosphoric acid is the ability to operate efficiently without the need for external humidification and the related engineering hardware to monitor and control the hydration levels in the membrane. This feature has been widely explored for portable and stationary PEM fuel cell devices, and numerous companies are developing systems based on PBI MEA's. Several years ago, a sol-gel process was developed to produce PBI membranes loaded with high levels of phosphoric acid. [1, 2] This process, termed the PPA process, uses polyphosphoric acid as the condensing agent for the polymerization and the membrane casting solvent. After casting, absorption of water from the atmosphere causes hydrolysis of the polyphosphoric acid to phosphoric acid. The change in the nature of the solvent induces a sol-to-gel transition that produces membranes with high loadings of phosphoric acid and a desirable suite of physical and mechanical properties. Membranes produced from this process showed the ability to maintain high levels of phosphoric acid and high proton conductivities while simultaneously exhibiting low levels of PA loss during standard operating conditions. In this presentation, we will describe some of our recent efforts on using PBI membranes for fuel cells and related sustainable energy devices. We will also present recent information on improving the mechanical properties of the membranes without sacrificing the high proton conductivities and results of long term durability and PA loss from these newer membranes.

1. Xiao, L.; Zhang, H.; Scanlon, E.; Ramanathan, L.S.; Choe, E.W.; Rogers, D.; Apple, T.; Benicewicz, B.C. Chem. Mater., 2005, 17, 5328-5333.

2. Xiao, L.; Zhang, H.; Jana, T.; Scanlon, E.; Chen, R.; Choe, E.-W.; Ramanathan, L.S.; Yu, S.; Benicewicz, B.C. Fuel Cells, 2005, 5(2), 287-295. 


\title{
9 - Oral presentation
}

\section{Physicochemical investigation of phosphoric acid doped poly(2,5-benzimidazole) as electrolyte membrane for fuel cells}

\author{
Anne Majerus $^{\mathrm{a}}$, Fosca Conti ${ }^{\mathrm{g}}$, Carsten Korte ${ }^{\mathrm{h}}$, Werner Lehnert ${ }^{\mathrm{i}}$, Detlef Stolten ${ }^{\mathrm{j}}$, \\ ${ }^{a}$ Forschungszentrum Jülich GmbH, Institute of Energy and Climate Research, IEK-3: Fuel Cells (a.majerus@fz- \\ juelich.de), ${ }^{9}$ Institute of Energy and Climate Research - Fuell Cells (IEK-3), Forschungszentrum Jülich GmbH, 52425 \\ Jülich, Germany Department of Chemical Sciences, University of Padova, Via Marzolo 1, 35131 Padova, Italy, \\ ${ }^{h}$ Forschungszentrum Jülich $\mathrm{GmbH}$, Institute of Energy and Climate Research, IEK-3: Fuel Cells, 'Forschungszentrum \\ Jülich $\mathrm{GmbH}$, Institute of Energy and Climate Research, IEK-3: Fuel Cells, ${ }^{\mathrm{j}}$ Forschungszentrum Jülich GmbH, \\ Institute of Energy and Climate Research, IEK-3: Fuel Cells,
}

\section{Summary}

We present a physicochemical investigation of phosphoric acid doped polybenzimidazole membranes, including conductivity measurements, thermogravimetric analysis and Raman spectroscopy.

Phosphoric acid doped polybenzimidazole membranes are a promising candidate for use as electrolyte membrane in high temperature polymer electrolyte membrane fuel cells (HTPEFC). They present high thermal stability and excellent proton conductivity at low humidity [1]. Although polybenzimidazole membranes are routinely doped with phosphoric acid, few studies on the exact nature of the acid inside the membrane have been published. It is not known whether the phosphoric acid is present as ortho- or pyrophosphoric acid at all operating conditions and how it interacts with the membrane at a high operating temperature of $160^{\circ} \mathrm{C}$. In this study, we investigated cross-linked poly(2,5-benzimidazole) (ABPBI) membranes obtained from FuMA-Tech $\mathrm{GmbH}$ which were doped in $85 \%$ phosphoric acid. Conductivity measurements of the doped membrane under dry conditions show a maximum conductivity at $160^{\circ} \mathrm{C}$. At higher temperatures, the conductivity decreases as the dehydration of the orthophosphoric acid to the less conductive pyrophosphoric acid becomes relevant. Thermogravimetric analyses of pure phosphoric acid and doped membranes help to assess the amount of dehydrated phosphoric acid as well as the content of water and phosphoric acid inside the doped membrane. The thermal signals show two distinct weight losses between $30^{\circ} \mathrm{C}$ and $200^{\circ} \mathrm{C}$, whose onset varies with the doping level of the membrane. An explanation for this effect, besides limited heat transfer, could be the bonds formed between the phosphoric acid molecules and the imidazole rings of the polymer. While free phosphoric acid molecules, found in pure phosphoric acid or in highly doped membranes, are free to condensate to pyrophosphoric acid molecules as soon as the activation energy is reached, bonded molecules need more energy to first break the bond and then dehydrate. To further consolidate these results, the structure of the as-received and phosphoric acid doped membranes were analyzed and compared by means of Raman spectroscopy [2]. They confirm the presence of hydrogen bonds between the phosphoric acid and the imidazole group of the membrane, thus supporting the results obtained by thermogravimetric analysis.

[1] Q. Li, J. O. Jensen, R. F. Savinell, and N. J. Bjerrum, Progress in Polymer Science, 34, 449 (2009)

[2] F. Conti, A. Majerus, V. Di Noto, C. Korte, W. Lehnert, and D. Stolten, Phys. Chem. Chem. Phys., DOI:10.1039/C2CP40553A 


\title{
10 - Oral presentation
}

\section{Electrospun Hybrid Membranes an alternative to Nafion?}

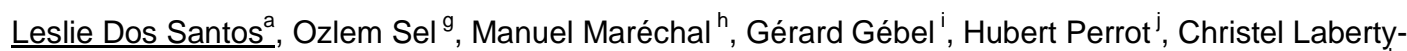 \\ Robert $^{k}$, \\ aLaboratoire de Chimie de la Matière Condensée de Paris, Université Pierre et Marie Curie - UMR 7574, Collège de \\ France (dossantos.leslie@gmail.com), ${ }^{9}$ Laboratoire d'Interfaces et Systèmes Electrochimique, UPR15-CNRS - \\ Université Pierre et Marie Curie, ${ }^{h} U J F$, CNRS, CEA, CEA Grenoble, UMR 5819, Structure \& Propriétés \\ d'Architectures Moléculaires, INAC, 38054 Grenoble 9, France, CNRS-Université de Grenoble, UMR 5279, \\ Laboratoire d'Electrochimie \& de Physico-chimie des Matériaux \& des Interfaces, BP 75, 'UJF, CNRS, CEA, CEA \\ Grenoble, UMR 5819, Structure \& Propriétés d'Architectures Moléculaires, INAC, 38054 Grenoble 9, France, \\ 'Laboratoire d'Interfaces et Systèmes Electrochimique, UPR15-CNRS - Université Pierre et Marie Curie, ${ }^{k}$ Laboratoire \\ de Chimie de la Matière Condensée de Paris, Université Pierre et Marie Curie - UMR 7574, Collège de France,
}

Proton exchange membrane fuel cells (PEMFC) have attracted great interest for future energy supply. PEMFC are a promising energy source for automobiles, portable electronics and residential power generation owing to their high power density, energy efficiency and environmental compatibility (low emission levels). Perfluorosulfonic polymers acid membranes, such as nafion, are typically the reference membranes for fuel cells due to their excellent chemical, mechanical, and thermal stability as well as their high electrochemical properties. However, PEMFCs have several drawbacks to overcome, including high cost, high catalyst loading and low carbon monoxide (CO) tolerance. In fact membrane moisturization is required to reach good conductivity. To avoid water evaporation, $80^{\circ} \mathrm{C}$ operating maximum temperature is used. The operating temperature must be increased above $100^{\circ} \mathrm{C}$ to limit the poisoning of $\mathrm{Pt}$ anode electrocatalysts by the $\mathrm{CO}$ in the hydrogen feed gas and to enable high energy consumption applications like transportation. Development of organic-inorganic hybrid membranes for fuel cell applications appears as an alternative to replace commercials membranes. A new hybrid membrane composed of silica and polymer PVDF-HFP is synthesised by combining sol gel chemistry and electrospinning. The association between the sol gel process and electrospinning permits the creation of an inorganic network within the polymer membrane, and morphological control to tune the proton pathway. Indeed, when nafion is hydrated, a nanophase separation occurs owing to the amphiphilic composition. This organisation is strongly correlated with high conductivity of nafion. The first results show PVDF-HFP fibbers coated with a mix of tetraethyl orthosilicate (TEOS) and 2-4(chlorosulfonylphenyl)ethyltrichlorosilane (CSPTC). This process recreated the nanoseparation observed in hydrated nafion while being in dependent of water quantity. This hybrid membrane combines the intrinsic physical and chemical properties of both the inorganic and organic components allowing desirable properties. Several characterisation techniques are used to explain the microstructure and to understand the link with conductivity values. Initial results indicate correlations between the ratio of TEOS/CSPTC, the electrospinning time and conductivity values. Mechanical tests have been performed and hybrid membranes exhibit better mechanical stability than nafion. 


\title{
11 - Invited Oral presentation
}

\section{Development of Durable High Temperature PEMFC MEA}

\author{
Jung Ock Park ${ }^{\mathrm{a}}$, SeongWoo Choi ${ }^{\mathrm{g}}$, Kyoung Hwan Choi ${ }^{\mathrm{h}}$, Hyuk Chang ${ }^{\mathrm{i}}$, \\ ${ }^{a}$ Samsung Electronics Co., Ltd. (jungock.park@samsung.com), ${ }^{9}$ Samsung Electronics Co., Ltd., "Samsung \\ Electronics Co., Ltd., 'Samsung Electronics Co., Ltd.,
}

\section{Summary}

The important parameters of catalyst, gas diffusion layer and membrane for high temperature PEMFC MEA will be identified, the significance of each parameter will be discussed.

The PEMFC that operates in the temperature range between $150{ }^{\circ} \mathrm{C}$ and $180^{\circ} \mathrm{C}$ often use phosphoric acid doped membrane as electrolyte, and the electrodes are partially filled with phosphoric acid to provide proton conductivity path between the two catalyst layers. Because of the relatively high operation temperature and the acid content in MEAs, it is challenging to maintain stable cell potential during long term operation. Low and high temperature PEMFC MEA share common factors of cell voltage decay such as catalyst oxidation, mechanical failure of membrane and collapse of electrode structure. However, the presence of acid in the MEA creates additional problems for the high temperature PEMFC MEA. The acid environment combined with the high operation temperature lead to fast degradation of catalyst. The catalyst degradation includes de-alloying of Pt catalyst, Pt dissolution and agglomeration, and oxidation of catalyst support material. The loss of acid during cell operation increases cell voltage decay rate by contributing to the increase of ohmic resistance and charge transfer resistance of MEA. In order to achieve the desired MEA life time of over $40,000 \mathrm{hrs}$, it is important to design the materials and structure of MEA so that it maintains cell voltage during operation. In the presentation, the design parameters of high temperature PEMFC MEA, and the effects that each parameters have on durability of high temperature PEMFC will be discussed. 


\section{2 - Oral presentation}

\section{Performance and degradation of high Performance MEAs For High Temperature PBI Fuel Cells}

Thomas Steenberg $^{\mathrm{a}}$, Hans Aage Hjuler ${ }^{\mathrm{g}}$, Carina Terkelsen $^{\mathrm{h}}{ }^{\text {, Hector R. García }}{ }^{\mathrm{i}}$, Thorsten Holst ${ }^{\mathrm{j}}$, a'Danish power Systems (ts@daposy.dk), ${ }^{9}$ Danish Power Systems, hDanish Power Systems, 'Danish Power Systems, 'Danish Power Systems,

Polybenzimidazole (PBI) membranes doped with phosphoric acid have been demonstrated to be the most successful system to achieve high temperature operation of proton exchange membrane fuel cells (PEMFC). Fuel cell technologies based on this membrane system have been demonstrated with operational features including no need for gas humidification, easy airflow and temperature control, simplified cooling, enhanced tolerance to fuel impurities and reasonable long-term durability. In this communication we report our recent progress in development and characterizations of Membrane Electrolyte Assemblies (MEAs). High molecular weight $\mathrm{PBI}$ and its variants have been synthesized, based on which different techniques for membrane preparation and reinforcement have been developed along with new methods for quality control. Electrodes have been manufactured in large amounts by an improved spraying technique. Finally high performance MEAs have been fabricated from these electrodes and membranes. The most recent findings related to durability and performance will be presented. 


\section{3 - Oral presentation}

\section{Development of mid temperature PEM membranes, catalysts and MEAs in the frame of the MT-PEMFC-Cluster project}

Volker Peinecke ${ }^{\mathrm{a}}$ Bastian Ruffmann ${ }^{\mathrm{g}}$, Ferdi Schüth ${ }^{\mathrm{h}}$, Jochen Meier-Haack ${ }^{\mathrm{i}}$, Matthias Langer ${ }^{\mathrm{j}}$, Falko Mahlendorf $^{\mathrm{k}}$, Manfred Baumgärtner ${ }^{\prime}$, Viktor Gogel ${ }^{\mathrm{m}}$, Joachim Scholta ${ }^{\mathrm{n}}$, Jean-Francois Drillet ${ }^{\mathrm{o}}$, Jochen Kerres $^{p}$, Günter Schöppe ${ }^{q}$,

aZBT (v.peinecke@zbt-duisburg.de), ${ }^{9} \mathrm{HIAT},{ }^{\mathrm{h}} \mathrm{MPI}$ Kohlenforschung, 'IPF, 'FILK, ${ }^{\mathrm{k}}$ University Duisburg-Essen, 'FEM, ${ }^{m}$ ZSW, " ZSW, ${ }^{\circ}$ DECHEMA, ${ }^{p}$ University Stuttgart, ${ }^{\mathrm{q} I U T A}$,

In the frame of the MT-PEMFC-Cluster project new PEM membranes, catalysts and MEAs as well as complete cells for mid temperature PEMFC applications (working range of 100 $150^{\circ} \mathrm{C}$ ) are being developed. The MT-PEMFC-Cluster receives common funding from DFG (Deutsche Forschungsgemeinschaft) and AIF (Allianz Industrie Forschung) in Germany, the planned overall duration is 3.5 years. The developmental work is split up in four projects, which are strongly interdependent: Membrane, Catalyst, Coating and Cell. Within the first project 'membrane' four different polymer development paths are pursued in parallel (phosphonated, sulfonated, acid excess, alkali excess polymer membranes). The second project 'catalyst' concerns the development of novel nano structured bimetallic catalysts for PEMFC and DMFC cathode applications. The 'coating' project comprises the development of coating procedures for making high performance and high lifetime gas diffusion electrodes (GDS's) and membrane electrode assemblies (MEA's), including low temperature MEA's and designing special high performance test cells. In the 'cell' project PEMFC and DMFC cells with special cooling concepts and advanced flow field designs for an operating temperature of above $120^{\circ} \mathrm{C}$ are being designed and tested. The status quo concerning material and test cell development, with the focus on new polymers, membrane conductivities, electrode properties and MEA performance will be presented. 
14 - Oral presentation

\title{
HT-PEM Fuel Cell: Compression Analysis by Electrochemical Characterization and Micro-Computed Tomography
}

\author{
Anja Diedrichs ${ }^{\mathrm{a}}$, Udo Martin $^{\mathrm{g}}$, Peter Wagner $^{\mathrm{h}}$, \\ ${ }^{a}$ NEXT ENERGY - EWE-Forschungszentrum für Energietechnologie e.V. (anja.diedrichs@next-energy.de), \\ ${ }^{g}$ Enymotion GmbH, ${ }^{h} \mathrm{NEXT}$ ENERGY - EWE-Forschungszentrum für Energietechnologie e.V.,
}

\begin{abstract}
A fuel cell is an emission-free energy converter when using hydrogen as fuel and oxygen/air as oxidant. Characteristics like rapid start-up time, preferential power-to-weight ratio and low sensitivity to orientation makes the polymer electrolyte membrane (PEM) fuel cell type suitable for stationary, transportation, portable and micro fuel cell applications. While the lowtemperature PEM fuel cell is based on water as liquid electrolyte, the high-temperature PEM fuel cell uses phosphoric acid. Therefore, the higher operating temperature of $\sim 160^{\circ} \mathrm{C}$ can be achieved without a complex compressor and humidification system. A better reaction kinetic and an enhanced carbon monoxide tolerance are further advantages of the higher operating temperature. Among other things, the performance of a HT-PEM fuel cell depends on the cell compression. The compressive force has an impact on the specific properties of each layer in the membrane-electrode-assembly (MEA) and their interfaces. For example, high compressive forces improve the contact between the interfaces but also deteriorate the reactant gas supply due to porosity loss in the gas diffusion layer. That means an optimum compressive force exists for a maximum fuel cell performance. In the presentation, the compression dependency of HT-PEM fuel cells is analyzed. For that purpose, current-voltage curves, electrochemical impedance spectroscopy, cyclic and linear sweep voltammetry experiments are carried out. Furthermore, the HT-PEM-MEAs are studied by micro-computed tomography (micro-CT). A specific compression tool has been developed in order to have the same conditions as in the fuel cell test station like flow-field geometry and compressive force range.
\end{abstract}


15 - Oral presentation

\title{
Latest advances in Alkaline Membrane Fuel Cell (AMFC) technology
}

\author{
Dario Dekel ${ }^{\mathrm{a}}$, \\ acellEra (dario@cellera.biz),
}

\section{Summary}

The AMFC is a blooming technology. Recently, AMFC stacks providing $2 \mathrm{~kW}$ power output were developed. In this presentation, AMFC state-of-the-art will be reviewed and discussed.

The Alkaline Membrane Fuel Cells (AMFCs) is a blooming new technology that has recently received increasing attention since they allow for the use of non-expensive metal catalysts, which dramatically reduces the cost per kW of power. Anion conductive membranes, anion conductive ionomers and catalysts able to work in an alkaline medium are key materials for this novel technology. Studies on these materials are now emerging. The advances done in this technology in the last couple of years allowed AMFC to reach a performance good enough for stationary applications, and potentially in the near future, for automotive applications. Today, the development of anion conductive polymers is blooming, and more than forty different polymer chemistries have been already studied and characterized. Both hydrocarbon as well as fluorinated backbones are being investigated. Although the $\mathrm{OH}-$ conductivities achieved in some polymers are high enough, their stability is still a concern, and novel more stable functional groups are currently being studied. From the limited materials developed for this technology, peak power density records of almost $200 \mathrm{~mW} / \mathrm{cm}^{2}$ were already achieved. Non-published data suggests that the actual power densities that can be achieved with today's state-of-the-art anion conductive polymers are even much higher. With the latest and most advanced developed materials, AMFC stacks providing $2 \mathrm{~kW}$ power output were already developed. During this presentation, the state-of-the-art on AMFCs will be reviewed, and current challenges in the development of membranes, ionomers and catalysts will be briefly discussed. 


\title{
16 - Oral presentation
}

\section{Polyethylene based anionic exchange membranes for solid alkaline fuel cells (SAFC)}

\author{
Syed Tauqir Ali Sherazi ${ }^{\mathrm{a}}$, Joon-Yong Sohn ${ }^{g}$, Shenghai $\mathrm{Li}^{\mathrm{h}}$, Michael D. Guiver ${ }^{\mathrm{i}}$, Young Moo Lee ${ }^{\mathrm{j}}$, \\ ${ }^{a}$ COMSATS Institute of Information Technology (sherazi_212@yahoo.com), ${ }^{9}$ Advanced Radiation Technology \\ Institute, Korea Atomic Energy Research Institute, Jeongeup-si, Jeollabuk-do 580-185, Korea, "WCU Department of \\ Energy Engineering, College of Engineering, Hanyang University, Seoul,133-791, Korea, 'Institute for Chemical \\ Process \& Environmental Technology, National Research Council, Ottawa, Ontario, K1A OR6, Canada, 'WCU \\ Department of Energy Engineering, College of Engineering, Hanyang University, Seoul,133-791, Korea,
}

Among various types of fuel cells, the SAFC is the most recent one and has advantages such as better kinetics of the oxygen reduction reactions and application of less expensive nonnoble catalysts such as silver and nickels contrary to expensive one (Platinum) required for proton exchange membrane fuel cell (PEMFC). AEM is a crucial part in solid alkaline fuel cell (SAFC), determining the durability and electrochemical performances of membrane electrode assembly (MEA). The role of an AEM is to conduct hydroxyl ions from cathode to anode. If this conduction is not sufficiently high and selective, the corresponding fuel cell will not find any practical application. One of the major problems associated with SAFC is much lower conductivities of anion compare to proton conductivity in PEMFCs, even upon similar working condition [1]. Thus AEMs is only practical, if it is chemically and mechanically stable against severe basic operation conditions and highly hydroxyl ions conductive. The conventional AEMs based on aminated aliphatic and aromatic hydrocarbon or even fluorinated polymers tend to be attacked by hydroxyl ion, causing the degradation during operation in strongly basic conditions [2]. In the present study, Vinyl benzyl chloride was grafted onto ultrahigh molecular weight polyethylene (UHMWPE) powder by $\mathrm{y}$-radiation grafting technique. The grafted powder was then converted into film by melt pressing. The main advantages of using UHMWPE are: its inexpensive nature, excellent bulk physical/chemical properties, crosslinking tendency upon exposure to $\mathrm{y}$-rays and above all it is quite stable to the alkaline medium. The grafted membranes were then reacted with various cationic functional groups, quaternary ammonium groups and modified guanidine groups in order to investigate the stability and hydroxyl ion conductivity. The performances of the AAEMs, including ion exchange capacity (IEC), water and methanol uptake (WU), In-plane swelling, methanol permeability, and ionic conductivity were investigated systematically. The thermal stability of the membranes was also determined. An interested feature has been observed that the ionic conductivity of PE-g-VBC-TMAOH membranes, with only $12.6 \%$ degree of grafting, approaches $0.05 \mathrm{~S} \mathrm{~cm}^{-1}$ at $90{ }^{\circ} \mathrm{C}$ while the corresponding methanol permeability is in the order of $10-8$ at $30^{\circ} \mathrm{C}$. The results indicate that the developed membranes can be possibly used as alkaline anion exchange membrane for fuel cells.

\section{Reference:}

1. F. Barbir, PEM Fuel Cells Theory and Practice, MA, 2005.

2. G. Couture, A. Alaaeddine, F. Boschet, B. Ameduri, Prog. Polym. Sci., 36, 1521-1557 (2011). 
17 - Oral presentation

\section{Aromatic block copolymers as anion exchange membranes}

Kenji Miyatake ${ }^{\mathrm{a}}$,

aUniversity of Yamanashi (miyatake@yamanashi.ac.jp),

\section{Summary}

Aromatic multiblock copolymers containing quaternized ammonio groups show high anion conductivity and good fuel cell performance with hydrazine fuel.

Aromatic multiblock copolymers composed of poly(arylene ether)s containing quaternized ammonio-substituted fluorene groups were developed for alkaline fuel cell applications. The quaternized multiblock copolymers (QPEs) gave ductile and transparent membranes. The membranes showed well developed hydrophobic/hydrophilic phase separation and interconnected ion transporting pathway, as confirmed by scanning transmission electron microscopic (STEM) observation. The QPE membranes showed considerably higher hydroxide ion conductivities, up to $144 \mathrm{mS} / \mathrm{cm}$ at $80{ }^{\circ} \mathrm{C}$, than those of existing anion conductive ionomer membranes. The QPE membranes were operated in a noble metal-free direct hydrazine fuel cell to show high power density. 
18 - Invited Oral presentation

\title{
Approaches to the mechanical stabilisation of highly functionalised membranes for medium and high temperature PEMFC
}

Deborah J. Jones ${ }^{a}$,

a ICGM-Aggregates, Interfaces and Energy Materials, University Montpellier 2, 34095 Montpellier cedex 5, France (deborah.jones@univ-montp2.fr),

\begin{abstract}
A broad array of polymers and ionomers have been developed and evaluated in recent years as possible components of membrane materials for proton exchange membrane fuel cells (PEMFC), with particular efforts dedicated to satisfying the exacting set of properties required for automotive use, and the extended durability requirements of stationary applications. While leading to a vast number of novel sulfonic acid functionalised non-fluorinated polyaromatics, as well as polymer materials comprising protogenic functions other than sulfonic acid, these endeavours have also notably advanced perfluorosulfonic acid technologies that have thence produced a new generation of benchmark fuel cell membranes. This presentation will point out current trends in the research for new membrane materials for low/medium and high temperature PEM fuel cells, with emphasis on strategies for improving the mechanical properties of highly functionalised PFSA and phosphoric acid doped polybenzimidazole membranes, and will highlight the advantages and disadvantages of the various approaches.
\end{abstract}




\title{
Proton Conducting Phase-Separated Multiblock Copolymers with Sulfonated Poly(Phenylene Sulfone) Blocks for Electrochemical Applications: Preparation, Morphology, Hydration, Mechanical Properties and Transport
}

\author{
Klaus-Dieter Kreuer ${ }^{\mathrm{a}}$, Giorgi Titvinidze ${ }^{\mathrm{g}}$, Michael Schuster ${ }^{\mathrm{h}}$, Carla Araujo ${ }^{\mathrm{i}}$, Jan P. Melchior ${ }^{\mathrm{j}}$, Wolfgang \\ H. Meyer ${ }^{k}$,
}

${ }^{a}$ Max-Planck-Institut für Festkörperforschung (kreuer@fkf.mpg.de), ${ }^{9} \mathrm{MPI}-\mathrm{P},{ }^{\mathrm{h}} \mathrm{Fumatech},{ }^{\mathrm{i}} \mathrm{MPI}-\mathrm{FKF},{ }^{\mathrm{j}} \mathrm{MPI}-\mathrm{FKF},{ }^{\mathrm{k}} \mathrm{MPI}-\mathrm{P}$,

\section{Summary}

New muliblock copolymers with high proton conductivity at high temperature, low electroosmotic drag and good eleastic properties at high $\mathrm{T}$ are reported.

We report on the preparation and characterization of a family of multiblock copolymers consisting of alternating fully sulfonated hydrophilic poly (phenylene sulfone) and hydrophobic poly (phenylene ether sulfone) segments. The multiblock copolymers were formed by the coupling of preformed hydrophilic and hydrophobic blocks with a specially designed coupling agent. The block lengths (degree of polymerization) of both segment types were varied as to control the ion exchange capacity within the range IEC $=1.2-1.7 \mathrm{meq} . / \mathrm{g}$. Solution cast films show spontaneous nano-phase separation leading to distinct bi-continuous morphologies with correlation lengths around $15 \mathrm{~nm}$. The hydrophobic phase donates the membranes their advantageous viscoelastic properties even at high temperature under wet and dry conditions, while transport (conductivity and diffusion) is taking place within the hydrophilic phase. Since the properties of fully sulfonated poly (phenylene sulfone)s (1-4) are locally preserved within the hydrophilic domain, the membranes show very high proton conductivity and high hydrolytic stability. Especially at high temperature, proton conductivity is slightly higher than that of Nafion. The very high degree of water dispersion within the hydrophilic domains leads to very low electroosmotic water drag, and the high local concentration of sulfonic acid functional groups within the distinct hydrophilic phases of the observed microstructures is thought to explain the proton conductivity to be more than one order of magnitude higher than that of statistically sulfonated poly (phenylene sulfone)s with similar ion exchange capacity. Thanks to their superior transport and stability properties the presented multiblock copolymers have a great potential to substitute for perfluorosulfonic acid membranes used as separator materials in electrochemical applications such as PEM fuel cells and redox flow batteries. The results are submitted for publication (5).

1. M. Schuster, K. D. Kreuer, H. T. Andersen, J. Maier Macromolecules 2007 40, 598

2. C. C. de Araujo, K. D. Kreuer, M. Schuster, G. Portale, H. Mendil-Jakani, G. Gebel, J. Maier Phys. Chem. Chem. Phys. 2009 11, 3305

3. M. Schuster, C. C. de Araujo, V. Atanasov, H.T. Andersen, K. D. Kreuer, J. Maier, Macromolecules 2009, 42, 3129-3137.

4. V. Atanasov et al., Polymer Bulletin 2011 68, 317

5. G. Titvinidze, K.D. Kreuer, M. Schuster, C. C. de Araujo, J. P. Melchior, and W. H. Meyer, 2012 submitted 
20 - Oral presentation

\title{
Proton Conducting Hydrophilic-Hydrophobic Multiblock Copolymers with Highly Sulfonated and Hydrolytically Stable Blocks
}

\author{
Shogo Takamuku ${ }^{a}$, Patric Jannasch ${ }^{9}$, \\ aLund University, Department of Chemistry (shogo.takamuku@polymat.Ith.se), ${ }^{9}$ Lund University, Department of \\ Chemistry,
}

Sulfonated polysufones (sPSUs) have been quite extensively investigated as fuel cell membrane materials because of their excellent mechanical strength, high thermal/chemical stability, high gas barrier properties and membrane forming ability, in addition to the availability of commercial monomers and polymers. However, these polymers are generally sensible towards desulfonation reactions which may lead to severe loss of conductivity and performance during prolonged operation at high temperatures. We have explored metalation chemistry that introduces sulfonic acid groups exclusively in ortho-positions to the sulfone bridges of PSUs. Recently, we have investigated the effect of the position of the acidic group on the membrane properties.[1] We found that polymers with sulfonic acid groups in orthopositions to sulfone bridges showed the best resistance against desulfonations, in relation to those with sulfonic acid groups in meta-positions to sulfone bridges and in ortho-positions to ether linkages. Our recent results on multiblock copolymers suggest that a stiff molecular structure of the hydrophilic unit of the copolymers favours high conductivity and dimensional stability.[2,3] Based on these findings, we have prepared novel multi-sulfonated monomers that can be used to prepare copolymers with high proton conductivity and dimensional stability. [4] The monomers were employed in polycondensations to achieve copolymers with a well-defined phase separation between hydrophilic and hydrophobic sequences, such as alternating and multiblock copolymers. For example, a tetrasulfonated monomer was prepared via lithiation, and then used in combination with benzenedithiol to prepare densely sulfonated hydrophilic precursor blocks. Multiblock copolymers obtained after coupling these blocks with non-sulfonated PSU blocks showed a comparable proton conductivity to that of Nafion ${ }^{\circledR}$ at a low relative humidity. Further details of the copolymers will be discussed in the presentation.

[1] S.Takamuku, P. Jannasch, Polym. Chem., 2012, 3, 1202;

[2] S.Takamuku, P. Jannasch, Macromol. Rapid Commun., 2011, 32, 474;

[3] S.Takamuku, P. Jannasch, Adv. Energy Mater., 2012, 2, 129;

[4] S.Takamuku, P. Jannasch (as applicants and inventors), Patent pending at the Swedish Patent Office. 


\title{
21 - Oral presentation
}

\section{Recent Development of Acid Doped Polybenzimidazole Membranes in Denmark - Polymer Chemistry and Durability Issues}

\author{
Qingfeng Li ${ }^{\mathrm{a}}$, Jens Oluf Jensen ${ }^{\mathrm{g}}$, Lars Nilausen Cleemann ${ }^{\mathrm{h}}$, David Aili ${ }^{\mathrm{i}}$, Jingshuai Yang ${ }^{\mathrm{j}}$, Thomas \\ Steenberg ${ }^{k}$, Carina Terkelsen ${ }^{\text {, Hans Aage Hjuler }}{ }^{\mathrm{m}}$, Niels J. Bjerrum ${ }^{\mathrm{n}}$, \\ ${ }^{\mathrm{a}}$ Technical University of Denmark (qfli@dtu.dk), ${ }^{\mathrm{g}} \mathrm{Technical}$ University of Denmark, ${ }^{\mathrm{h}} \mathrm{Technical}$ University of Denmark, \\ 'Technical University of Denmark, 'Technical University of Denmark, ${ }^{k}$ Danish Power Systems, 'Danish Power \\ Systems, " Danish Power Systems, ${ }^{\mathrm{n}}$ Technical University of Denmark,
}

\section{Summary}

Progress in polybenzimidazole based membranes was summarized by focusing on the recent results jiontly achieved by the Danish Power Systems and Technical University of Denmark.

Phosphoric acid doped polybenzimidazole membranes represent an effective approach to achieving a high temperature operation of proton exchange membrane fuel cells (PEMFC). Fuel cells using this type of membranes have been successfully demonstrated both in laboratory and industrial scales. Operating features include non-mandatory gas humidification, easy control of air flowrate and cell temperature, higher $\mathrm{CO}$ tolerace and possible integration with fuel processors. HT-PEMFC was in Denmark recognized as one of the main approaches of the national PEMFC development. Major Danish efforts, as primarily funded by the Public Service Obligations (the ForskEL programme), the Danish Energy Authorities (the EUDP programme) and High Technology Fund, cover all linkages of the technological chain from polymers and membranes, catalysts and electrodes, membraneelectrode assemblies, stacks, management control and complete power units. This presentation is devoted to a summary of the recent membrane development, as jointly achieved by Danish Power Systems and Technical University of Denmark. To optimize the membrane properties, high molecular weight polymers were synthesized. Membranes based on the polymers were characterized by spectroscopy, water uptake and acid doping, proton conductivity, water drag, as well as solubility and permeability of gases. As a critical concern, issues of long term durability of PBI based membranes and fuel cells have been particularly addressed. The polymer degradation by thermal and radical oxidation was investigated in the presence of phosphoric acid. Improvement of the membrane performance in terms of chemical (thermal and oxidative) stability, mechanical strength, swelling and fuel cell durability was achieved by optimization of polymer chemistry. Polymer variants, e.g. poly(aryl sulfone benzimidazole) $\left(\mathrm{SO}_{2}-\mathrm{PBI}\right)$ and its copolymers with poly[2,2' $-\mathrm{p}$-(phenylene)-5,5'bibenzimidazole](pPBI), hexafluoropropylidene polybenzimidazole $\left(\mathrm{F}_{6}-\mathrm{PBI}\right)$ and its crosslinked analogues, were synthetically prepared. Cross-linking with ionic or covalent, small molecular or polymeric cross-linkers, as well as inorganic-organic composites, was extensively explored. Associated with the polymer and membrane development, fuel cell durability tests were performed and are discussed with focus on polymer membrane degradation. 


\title{
22 - Oral presentation
}

\section{Phosphorus-doped ordered mesoporous carbon: effect of size on electrocatalytic activity towards oxygen reduction}

\author{
Jong-Sung $\mathrm{Yu}^{\mathrm{a}}$, Dae-Soo Yang ${ }^{\mathrm{g}}$, Jinsol Park ${ }^{\mathrm{h}}$, Min Young Song ${ }^{\mathrm{i}}$, Hyun-Yeol Park ${ }^{\mathrm{j}}$, \\ a Korea University (jsyu212@korea.ac.kr), ${ }^{9}$ Korea University, " Korea University, 'Korea University, ${ }^{\mathrm{j}}$ Korea University,
}

\author{
Summary \\ P-doped carbon electrode, oxygen reduction reaction in PEM fuel cell, mesoporous carbon
}

Fuel cells are expected as a major source of clean energy, particularly for automobile and portable electronic applications [1]. Platinum based materials have long been investigated as active catalysts for oxygen reduction reaction (ORR) [2-4]. However, the large-scale application of fuel cells has been disturbed by the high cost and shortage of the precious $\mathrm{Pt}$ metal. In this work, we report the fabrication of novel phosphorus-doped ordered mesoporous carbon (P-OMC) nanorods on the basis of nanocasting method using rodtype ordered mesoporous silica SBA-15 as template with triphenylphosphine (TPP) as a P source and phenol as a carbon precursor [5]. The electrocatalytic performances show that the P-OMC nanorods exhibit comparable or better catalytic activity and long-term stability than a commercial Pt/C catalyst towards ORR. Our work demonstrates not only successful preparation of a new type of P-OMC with excellent electrocatalytic activity, but also interesting size effect of Pt-free P-doped carbon nanorods on the ORR. Fig. 1 Schematic illustration of the synthesis procedure of rodtype P-doped ordered mesoporous carbon by nanocasting method and ORR activity

\section{References}

[1] H.A. Gasteiger, S.S. Kocha, B. Sompalli, F.T. Wagner, Applied Catalysis B: Environmental., 200556 9B.C.

[2] B. Fang, J. H. Kim, M.-S. Kim, J.-S. Yu, Chem. Mater., 2009, 21, 789.

[3] J. Zhang, K. Sasaki, E. Sutter, R. R. Adzic, Science 2007, 315, 220.

[4] B. Lim, M. J. Jiang, P. H. C. Camargo, E. C. Cho, J. Tao, X. M. Lu,Y.M. Zhu, Y. N. Xia, Science., 2009, 324, 1302.

[5] S. Kang, Y. B. Chae, J. -S. Yu, J. Nanosci. Nanotech. 2009, 9, 527. 
23 - Oral presentation

\section{A new concept for noble metal-free cathode catalysts based on metalorganic Fe and Co compounds in ordered mesoporous carbon}

Johanna K. Dombrovskis ${ }^{a}$, Hu Young Jeong ${ }^{g}$, Kjell Fossum ${ }^{\text {h }}$, Osamu Terasaki ${ }^{i}$, Anders E.C. Palmqvist

${ }^{a}$ Department of Chemical and Biological Engineering, Applied Surface Chemistry, Chalmers University of Technology, SE-412 96 Göteborg, Sweden (harterj@chalmers.se), ${ }^{9}$ UNIST Central Research Facilities (UCRF),

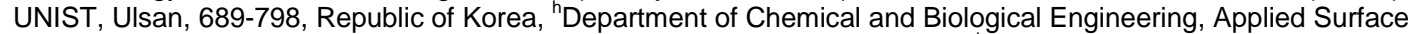
Chemistry, Chalmers University of Technology, SE-412 96 Göteborg, Sweden, 'Graduate School of EEWS (WCU), KAIST, Daejeon 305-701, Republic of Korea, 'Department of Chemical and Biological Engineering, Applied Surface Chemistry, Chalmers University of Technology, SE-412 96 Göteborg, Sweden,

Iron- and cobalt-containing catalysts for PEM fuel cells are promising alternatives to expensive platinum-containing catalysts and in recent years major improvements in the performance of these alternative materials have been achieved [1]. The materials presented here illustrate a new synthesis approach for non-noble metal-containing catalysts. The materials were synthesized in a one pot approach [2], by a modified synthesis route for highly ordered mesoporous carbons (OMCs) [3]. The OMC synthesis was modified to include a source of nitrogen as well as iron and/or cobalt salts. Using this approach active sites were directly incorporated inside a highly porous electron conducting support material. This results in a material with much higher specific surface area compared to conventional Vulcan supported catalyst materials. Furthermore the synthesis method may be tuned by careful selection of a large number of synthesis variables. Thus the influence of changes in the synthesis on the mesostructure of the matrix and the atomic local structure of the active sites was studied. Electrochemical characterization was done in a single cell fuel cell setup. Nitrogen physisorption, SAXS, HR-TEM and SEM were used to examine the mesostructure, while the atomic local structure of the catalysts was characterized by EXAFS. The study showed that it is possible to synthesize metalorganic oxygen reduction reaction catalysts using a one-pot approach. The material is free from metal clusters and Fe and Co atoms are organically bound. Furthermore it is possible to greatly vary the material structure on the mesoscale without disturbing the atomic-scale active site structure. This allows for a large tuneability in surface area, pore size and wall thickness of the catalyst materials.

[1] Z. Chen, D. Higgins, A. Yu, L. Zhang, J. Zhang, Energy \& Environmental Science, 4 (2011) 3167.

[2] J.K. Dombrovskis, H. Hyung, K. Fossum, O. Terasaki, A.E.C. Palmqvist (2012) Manuscript submitted

[3] R. Ryoo, S.H. Joo, M. Kruk, M. Jaroniec, Advanced Materials, 13 (2001) 677. 
24 - Oral presentation

\title{
New Approaches for the Characterization of Porous Electrodes Devoted to Oxygen Reduction
}

\author{
$\underline{\text { Henri Perez }}^{\mathrm{a}}$, Mathieu Pinault ${ }^{\mathrm{g}}$, Martine Mayne ${ }^{\mathrm{h}}$, Elie Sayah ${ }^{\mathrm{i}}$, Arnaud Etcheberry $^{\mathrm{j}}$, Xi Cheng $^{\mathrm{k}}$, Elodie \\ Pardieu', \\ ${ }^{\mathrm{a}} \mathrm{CEA}$ (henri.perez@cea.fr), ${ }^{9} \mathrm{CEA},{ }^{\mathrm{h}} \mathrm{CEA},{ }^{\mathrm{i}} \mathrm{CNRS},{ }^{\mathrm{j}} \mathrm{CNRS},{ }^{\mathrm{k}} \mathrm{CEA} / \mathrm{ADEME},{ }^{\mathrm{C}} \mathrm{CEA}$,
}

\section{Summary}

The determination of the specific area of porous electrodes related to the ORR is presented in combination with an alternative method to RRDE and RDE utilization for the ORR selectivity measurement.

We present an overview of our research on the elaboration and characterization of porous electrodes for fuel cells, using a bottom-up approach. It involves the synthesis of various original Platinum Organically Grafted Electrocatalalysts (Pt-OGE) and carbon nanotubes (CNT), and their controlled combination to form nanocomposites. Using specific surface areas (SSA) for both, Pt-OGE's and CNT, the average coverage density at the CNT surface for a given Pt-OGE can be precisely controlled in liquid nanocomposite dispersions (Pt-OGE/CNT ratio). The later is used to form an active layer on a carbon felt support, having a determined $\mathrm{Pt}$ loading ( $\mu \mathrm{gPt} / \mathrm{cm}^{2}$ of active layer). Thus, collections of electrodes with increasing $\mathrm{Pt}$ loading are formed, this for a given Pt-OGE and a given Pt-OGE/CNT ratio [1]. Various kind of Pt-OGE's can be synthesized: those with a Low Molecular Weight Organic corona (PtLMWO) and a low SSA and those with a high molecular weight organic corona (Pt-HMWO) and a high SSA [2]. Collections of electrodes with increasing platinum loadings are prepared, with Pt-LMWO or Pt-HMWO set at different coverage densities at the CNT surface. Because Pt-OGE's exhibit a low or non-measurable Pt-EASA [1] cyclic voltammetry is used to determine the porous electrode area (called ADiffO2) related to the ORR [3]. $\mathrm{ADiffO}_{2}$ determination necessitates the knowledge of the selectivity for the ORR (n). Due to the difficulties for controlled Pt-OGE/CNT systems deposition (homogeneity and loading) on rotating disc electrodes we developed an alternative method for $n$ measurement on porous electrodes [4]. Beyond the interest of the method by itself, specific $\mathrm{ADiffO}_{2}$ in $\mathrm{m}^{2} \cdot \mathrm{g}^{-1}$ of electrocatalyst showed highly consistent trends as a function of electrocatalyst loading and appear as a feature parameter for the characterization of porous electrode structures devoted to the ORR. Finally, examples are given for Nitrogen doped carbon nanotubes and combination Pt-OGE's with carbon blacks.

1. B. Baret, P-H Aubert, M. Mayne- L'Hermite, M. Pinault, C. Reynaud, A. Etcheberry, H. Perez Electrochim. Acta 54 (2009) 5421-5430

2. G. Carrot, F. Gal, C. Cremona, J. Vinas, H. Perez Langmuir 25 (2009), 471

3. G. March, F. Volatron, F. Lachaud, X. Cheng, B. Baret, M. Pinault, A. Etcheberry, H. Perez Electrochim. Acta 56 (2011) 5151-5157

4. X. Cheng, L.Challier, A. Etcheberry, V. Noel, H. Perez, Int. J. Electrochem.Sci. online June 2012 
25 - Oral presentation

\title{
Electrocatalytic activity and stability of antimony doped tin oxide supported platinum catalyst for PEM fuel cells
}

\author{
Magnus Thomassen ${ }^{\mathrm{a}}$, Edel Sheridan ${ }^{\mathrm{g}}$, Luis Colmenares ${ }^{\mathrm{h}}$, \\ ${ }^{a}$ SINTEF Materials and Chemistry (magnus.s.thomassen@sintef.no), ${ }^{9}$ SINTEF Materials and Chemistry, ${ }^{\text {h }}$ SINTEF \\ Materials and Chemistry,
}

\section{Summary}

A higly stable Pt/ATO catalyst for the cathode in PEM fuel cells have been synthesised and the electrochemical activity and stability is investigated using both ex-situ and in situ experiments.

An antimony-doped tin oxide supported platinum catalyst was synthesized using a modified polyol method. TEM analysis revealed that the $20 \mathrm{wt} \%$ Pt/ATO consisted of Pt particles with a diameter of 3-4 $\mathrm{nm}$ were deposited on the ATO support. The Pt/ATO catalyst showed comparable oxygen reduction reaction (ORR) activity to that of a commercial $\mathrm{Pt} / \mathrm{C}$ catalyst when tested with $s$ rotating ring-disk electrode (RRDE) in $0.5 \mathrm{M} \mathrm{H}_{2} \mathrm{SO}_{4}$. Results of several accellereated durability tests indicated high stability of the Pt/ATO electrocatalysts in terms of minimum loss in Pt electrochemical surface area (ECSA). Investigations of the electrocatalytic activity and stability under PEM fuel cell operation is ongoing and results from these experiments will be presented. 


\title{
26 - Invited Oral presentation
}

\section{Carbon Nanotube/PBI Composites as a Material for the Future PEMFC Electrocatalyst}

\author{
Naotoshi Nakashima $^{a}$, Tsuyohiko Fujigaya ${ }^{\mathrm{g}}$, \\ ${ }^{a}$ Kyushu University (nakashima-tcm@mail.cstm.kyushu-u.ac.jp), ${ }^{9}$ Kyushu University,
}

\begin{abstract}
Summary
We report our study on the design of i) polybenzimidazole (PBI)-wrapped carbon nanotube (CNTs)/Pt composites, and ii) a nitrogen-containing calcined PBI/CNT hybrids for fuel cell electrocatalysts.
\end{abstract}

One of the key issues in the utilization of carbon nanotubes (CNTs) for basic researches together with their potential applications in many areas is to develop a methodology to solubilize/disperse them in solvents.[1] After brief introduction about the strategy to solubilize CNTs in solution, we report our recent study on the electrocatalyst for fuel cell using soluble CNTs.[2-5] In polymer electrolyte fuel cells, proton-exchange membrane fuel cells (PEMFCs) have been recognized as a promising energy source system due to their high energy conversion efficiency, high power density, and low pollutant emission. However, the crucial drawbacks of the PEMFCs, such as temperature limitation for operation and low durability of metal catalysts under acidic conditions, are offending their commercialization. Recently, our group reported an advanced functionalization process, in which the CNTs were m-stacked with unique proton conducting polymers (benzene-based polybenzimidazole; PBI, and pyridine-based polybenzimidazole; PyPBI). The polymer wrapped-CNTs were then used as precursors for the deposition of Pt nanoparticles [2-5]. In order to show how CNTs support high performance PEMFCs, an advanced electrocatalyst based on CNTs was successfully synthesized by a deposition process of a Pt metal catalyst onto a proton conducting polymerwrapped CNT composite. The fuel cell performances of the CNT-based and CB-based MEAs were successfully optimized through improvement of the $\mathrm{PBI}$ membrane properties. The higher FC performance recorded in the case of the CNT-based MEA at different operating temperatures was due to the highly porous and tortuous structure of the CNTs that offered more accessible catalytic sites and enhanced gas diffusion processes into the electrocatalyst layer. We also report our study on the design and synthesis of nitrogen-containing calcined polybenzimidazole $(\mathrm{PBI}) /$ carbon nanotube hybrids that act as an oxygen reduction catalyst [5].

\section{References}

[1] N. Nakashima et al.,"Solubilized Carbon Nanotubes and Their Redox Chemistry", in Carbon Nanomaterials, Ed. by F. D'Souza and K. M. Kadish, World Scientific, pp. 245269, 2011.

[2] T. Fujigaya et al., Carbon, 2009, 47, 3227-3232.

[3] M. Okamoto et al., Small, 2009, 5, 735-740.

[4] K. Matsumoto et al., J. Mater. Chem. 2011, 21, 1187-1190.

[5] T. Fujigaya et al., ChemCommun, 2011, 47, 6843. 


\title{
27 - Oral presentation
}

\section{Novel Electrocatalyst Support Materials for High Temperature PEMFC}

\author{
Amrit Chandan ${ }^{\mathrm{a}}$, Jonathan $\mathrm{Goh}^{\mathrm{g}}{ }^{\text {, Shangfeng } \mathrm{Du}^{\mathrm{h}} \text {, Surbhi Sharma }}{ }^{\mathrm{i}}$, Andrew Ingram ${ }^{j}$, Waldemar Bujalski \\ k, Sammy Lap Ip Chan', Valerie Self ${ }^{\mathrm{m}}$, John Richmond ${ }^{\mathrm{n}}$, \\ a'University of Birmingham (asc733@bham.ac.uk), ${ }^{9}$ University of Birmingham, 'University of Birmingham, 'University \\ of Birmingham, 'University of Birmingham, ${ }^{\mathrm{k}}$ University of Birmingham, 'University of New South Wales, ${ }^{\mathrm{m}} \mathrm{Tata}$ Motors, \\ ${ }^{\mathrm{n}}$ Tata Motors,
}

High Temperature Polymer Electrolyte Membrane (HT-PEM) fuel cells have many benefits, including improved tolerance to impurities, higher quality heat and opportunities for lower catalyst loadings. However, there are issues regarding the optimization of the components that make up the membrane electrode assembly (MEA), such as the thickness of the catalyst layer. This study looks at the optimization of the catalyst layer by the comparison of different catalyst-support conjugates/systems. The performance of Pt nanoparticles as electrocatalysts was compared on three different supports: (i) commercial Carbon Black (CB), (ii) Carbon Nanotube based buckypaper (CNT), (iii) reduced Graphene Oxide ( $\mathrm{rGO}$ ) in HT conditions. Previous studies have confirmed that CNT papers significantly improve the cathode catalyst stability as it is highly corrosion resistant. It can also prevent flooding of the catalyst layer by maintaining the electrode structure and hydrophobicity for a long period of time under continuous anodic potential stress $[1,2]$. Depending on the technique employed to prepare catalyst-CNT conjugates, it could be possible to attain higher Electrochemical Active Surface Area (ECSA) and improved CO tolerance compared to conventional Pt/C [2]. Similarly, $\mathrm{Pt} / \mathrm{rGO}$ has been reported to show increased CO-tolerance in DMFC and high ECSA which should improve the oxygen reduction reaction (ORR) [3-7]. Ex-situ electrochemical characterizations suggest that the Pt/rGO should give the best performance in the fuel cell. Testing has shown that the ECSA is much higher for Pt/rGO than for Pt/C $[3,7]$. These characteristics are expected to be enhanced under HT-PEM conditions, further improving the kinetics. In this study, colloidal catalyst inks were hand painted onto the carbon substrate before being hot-pressed into an MEA. MEAs prepared using the three different catalyst support systems were tested. Preliminary results were found to be very interesting, with neither $\mathrm{Pt} / \mathrm{rGO}$ nor $\mathrm{Pt} / \mathrm{CNT}$ performing as well as $\mathrm{CB}$ under the real fuel cell conditions. Further studies are to be conducted to see if the formulation of catalyst ink can be fine-tuned to produce a better performing MEA.

1. Park S., et al., J. Electrochem. Soc., 2011 158: p. B297.

2. Sharma, S., et al., Journal of Power Sources, 2012 208(0): p. 96.

3. Seger, B., et al., The Journal of Physical Chemistry C, 2009 113(19): p. 7990.

4. Sharma, S., et al., The Journal of Physical Chemistry C, 2010 114(45): p. 19459.

5. Yoo, E., et al., Nano Letters, 2009 9(6): p. 2255.

6. Ha, H.W., et al., Electrochem. Solid State Lett., 2011 14(7): p. B70

7. Chartarrayawadee, W., et al., Electrochimica Acta, 2012 60(0): p. 213 


\section{8 - Oral presentation}

\section{Evaluation of crack structures in catalyst layers of dynamically operated HT-PEFCs from in situ synchrotron X- ray radiographs}

$\underline{\text { Wiebke Maier }}^{\mathrm{a}}$, Dieter Froning ${ }^{\mathrm{g}}$, Tobias Arlt ${ }^{\mathrm{h}}$, Jennifer Groß ${ }^{\mathrm{i}}$, Christoph Wannek ${ }^{\mathrm{j}}$, Ingo Manke ${ }^{\mathrm{k}}$, Werner Lehnert ', Detlef Stolten ${ }^{\mathrm{m}}$,

${ }^{\mathrm{a}}$ Forschungszentrum Jülich GmbH (w.maier@fz-juelich.de), ${ }^{9}$ Forschungszentrum Jülich $\mathrm{GmbH},{ }^{\mathrm{h}} \mathrm{Helmholtz-Zentrum}$ Berlin, ${ }^{i}$ Forschungszentrum Jülich $\mathrm{GmbH}$, ${ }^{\mathrm{j}}$ Forschungszentrum Jülich $\mathrm{GmbH}$, ${ }^{\mathrm{k}} \mathrm{Helmholtz-Zentrum}$ Berlin, 'Forschungszentrum Jülich $\mathrm{GmbH}$, ${ }^{\mathrm{m}}$ Forschungszentrum Jülich $\mathrm{GmbH}$,

\section{Summary}

The analysis of HT-PEFC radiographs by using morphological criteria is a promising method to investigate the influence of different fuel cell parameters on the crack structure of catalyst layers.

One of the main goals for high-temperature polymer electrolyte fuel cells (HT-PEFCs) is to enhance the fuel cell performance under different operating conditions. For the optimization two approaches are suggested: i) the improvement of the membrane electrode assembly (MEA) and ii) the improvement of the cell design. The impact of changing operating conditions on structural changes in a HT-PEFC is not easy to depict, but with through-plane synchrotron X-ray radiography, subtle interrelationships between the crack structure of the catalyst layers and the influence of different flowfield geometries can be depicted. In situ synchrotron X-ray radiography measurements were carried out in through-plane viewing direction from a dynamically operated HT-PEFC in order to gain insight into the electrode structure. In particular, the width of the crack structure of the catalyst layers under the channels and the ribs depending on the fuel cell compression and flowfield geometry are of special interest. Therefore, radiographs were taken from the MEA in through-plane viewing direction during fuel cell operation, in order to visualise the micro structure of the cracks originated by the manufacturing process of the electrodes. The information regarding the cracks widths was obtained in four steps. In a first step the radiographs had to be separated into the areas under the channels and under the ribs. In a second step these different sections of the radiographs were converted into two-dimensional grey scale images and in a third step into black-and-white images. Finally, for the investigation these structures a radar method was developed in order to obtain the width of the cracks at many positions resulting in a distribution of cracks widths. These distributions of cracks widths from the separated images were analysed with a stochastic method, the Mann-Whitney U-test. The test was applied to check: i) if both data sets (under the channels and ribs) are samples from the same population, ii) if the values from the first data set (channels) are smaller than those from the second (ribs), or iii) if the values from the first data set (channels) are greater than those from the second (ribs). For all images taken at various operating conditions the stochastic test proves that the cracks under the channels are nearly twice as wide as those under the ribs. When comparing images from the same section changes in crack widths as a function of the operating conditions can be visualized. 
29 - Oral presentation

\title{
Self-supporting Microporous Layers (MPLs) for PEM fuel cells
}

\begin{abstract}
Alexander Bauder ${ }^{\mathrm{a}}$, Jan Haußmann ${ }^{\mathrm{g}}$, Henning Markötter ${ }^{\mathrm{h}}$, Robert Alink ${ }^{\mathrm{i}}$, Ingo Manke ${ }^{\mathrm{j}}$, Joachim Scholta ', Kaspar Andreas Friedrich!,

${ }^{a}$ Deutsches Zentrum für Luft- und Raumfahrt (DLR), Institut für Technische Thermodynamik, Pfaffenwaldring 38-40, 70569 Stuttgart, Germany (alexander.bauder@dlr.de), ${ }^{9}$ Zentrum für Sonnenenergie- und Wasserstoff-Forschung (ZSW), Helmholtzstr. 8, 89081 Ulm, Germany, hHelmholtz Zentrum Berlin für Materialien und Energie (HZB), HahnMeitner-Platz 1, 14109 Berlin, Germany, 'Frauenhofer Institute for Solar Energy Systems (ISE), Heidenhofstr. 2, 79110 Freiburg, Germany, ${ }^{\mathrm{j}}$ Helmholtz Zentrum Berlin für Materialien und Energie (HZB), Hahn-Meitner-Platz 1, 14109 Berlin, Germany, ${ }^{k}$ Zentrum für Sonnenenergie- und Wasserstoff-Forschung (ZSW), Helmholtzstr. 8, 89081 Ulm, Germany, 'Deutsches Zentrum für Luft- und Raumfahrt (DLR), Institut für Technische Thermodynamik, Pfaffenwaldring 38-40, 70569 Stuttgart, Germany,
\end{abstract}

The main requirements of a gas diffusion layer (GDL) of polymer electrolyte membrane fuel cells (PEMFC) are the provision of a gas and water transport as well as a significant electrical and thermal conductivity. The development of membrane electrode assemblies (MEA) for a wide temperature range $\left(-20^{\circ} \mathrm{C}\right.$ until $\left.+130^{\circ} \mathrm{C}\right)$ still favours membranes that require a certain level of humidification for sufficient proton conductivity. For the improvement of PEMFC diffusion media for these conditions, the still mostly unknown influence of the micro porous layer (MPL) on fuel cell performance is a major obstacle. An important function of the cathode side MPL at high temperature operation of PEMFCs is the prevention of membrane drying. However, concurrently a flooding of porous structures in the GDL or catalyst layers at lower temperatures has to be avoided. To get an insight that could lead to an improved GDL design for a broad range of operating conditions, a self-supporting MPL was developed, because this allows the manufacturing and the following treatments of the MPL independent from the GDL substrate. This MPL consists of a thin nonwoven synthetics coated on one side with a mixture of carbon and PTFE produced with the dry spraying technology [1]. For in-situ experiments and some ex-situ measurements these layers are pressed with the non coated side on a commercial GDL without MPL (Sigracet ${ }^{\circledR}$ GDL25BA from SGL). To get a correlation of fuel cell performance to the global intrinsic properties of the MPL, like through-plane permeability, electrical conductivity or hydrophobicity, U(i)-curves up to limiting current densities and electrochemical impedance spectra are measured in a $5 \mathrm{~cm}^{2}$ fuel cell setup. To obtain information about the influence of MPL structure on water distribution, synchrotron X-ray radiography studies were performed additionally. In such studies the importance of liquid water pathways through the porous structure for the water management is proven [2]. With artificial paths in a carbon fibre GDL produced by laser perforation an overall performance gain has been obtained [3]. With self-supporting MPLs it was feasible to investigate the liquid water transport of nonperforated GDL/MPLs compared to the perforation of both layers as well as to the exclusive perforation of MPL and the GDL, by means of in-situ synchrotron imaging.

\section{References:}

[1] E. Gülzow et al., Fuel Cell Bulletin 15 (1999)8

[2] H. Markötter et al., Electrochemistry Communications 13 (2011)1001

[3] D. Gerteisen et al., Journal of Power Sources 177 (2008)348 
30 - Invited Oral presentation

\title{
Mobility and distribution of phosphoric acid in high- temperature polymer electrolyte fuel cells
}

\author{
Werner Lehnert $^{\mathrm{a}}$, Wiebke Maier $^{\mathrm{g}}$, Christoph Wannek ${ }^{\mathrm{h}}$, Tobias Arlt ${ }^{\mathrm{i}}$, Ingo Manke ${ }^{\mathrm{j}}$, Detlef Stolten ${ }^{\mathrm{k}}$, \\ ${ }^{a}$ Forschungszentrum Jülich, Institut of Energy and Climate Research, IEK-3 (Fuel Cells) (w.lehnert@fz-juelich.de), \\ ${ }^{9}$ Forschungszentrum Jülich, Institut of Energy and Climate Research, IEK-3 (Fuel Cells), h'Forschungszentrum Jülich, \\ Institut of Energy and Climate Research, IEK-3 (Fuel Cells), 'Helmholtz-Zentrum Berlin, Institute for Applied \\ Materials, ${ }^{j} \mathrm{Helmholtz-Zentrum} \mathrm{Berlin,} \mathrm{Institute} \mathrm{for} \mathrm{Applied} \mathrm{Materials,}{ }^{\mathrm{k}}$ Forschungszentrum Jülich, Institut of Energy \\ and Climate Research, IEK-3 (Fuel Cells),
}

\section{Summary}

The mobility and hydration/dehydration of phosphoric acid in HT-PEFC MEAs was observed in situ with synchrotron X-ray measurements in combination with impedance spectroscopy.

In high temperature polymer electrolyte fuel cells (HT-PEFC) the proton conductivity relies on phosphoric acid doped polybenzimidazole as electrolyte. In our studies we used poly (2,5benzimidazole) (ABPBI) provided by the company FuMaTech. We showed that the performance of cells is almost independent of the way of acid introduction into the membraneelectrode-assembly (MEA) but strongly depends on the amount inserted into it. The doping of the membrane was done via phosphoric acid impregnated electrodes with and without predoped membranes. The electrodes and the membrane were assembled in the cell without a previous hot press step. The cells were afterwards operated under standard conditions. Chemical analysis after shut down revealed that in all these MEAs the phosphoric acid distribution between the membrane and the electrodes was nearly the same. Furthermore a rapid start-up of MEAs impregnated with phosphoric acid via the electrodes was possible. These experiments indicate very fast kinetics of the redistribution of phosphoric acid within the MEA being accelerated by gaseous product water from the fuel cell operation. In order to observe the redistribution and hydration/dehydration of phosphoric acid in situ, impedance measurements and synchrotron X-ray radiography measurements were carried out during operation of cells at different operating conditions. Differently conditioned cells were investigated during the heating-up. For one cell, a classical $70 \mathrm{~h}$ break-in procedure was performed while for the other cell, which was assembled two hours before starting the experiments, no break-in procedure was carried out. Furthermore, cells were examined during load changes. The results show that the local distribution of phosphoric acid in the MEA and the thickness of the membrane are dependent on the operating conditions due to hydration and dehydration process. Moreover the results allow an estimation of the concentration of the phosphoric acid in the membrane at the different current densities applied. 
31 - Oral presentation

\title{
Comparative experimental study of the performance of two different types of high temperature polymer electrolyte membrane electrode assemblies
}

\author{
$\underline{\text { Søren Juhl Andreasen }}{ }^{\mathrm{a}}$, Jakob Rabjerg Vang ${ }^{\mathrm{g}}$, Søren Knudsen Kær ${ }^{\mathrm{h}}$, Thomas Steenberg ${ }^{\mathrm{i}}$, Hans Aage \\ Hjuler $^{j}$, Lars Nilausen Cleemann ${ }^{k}$, \\ ${ }^{a}$ Aalborg University / Department of Energy Technology (sja@et.aau.dk), ${ }^{9}$ Aalborg University / Department of Energy \\ Technology, " Aalborg University / Department of Energy Technology, 'Dansih Power Systems A/S, 'Danish Power \\ Systems A/S, ${ }^{k}$ Technical University of Denmark / Department of Energy Conversion and Storage,
}

\section{Summary}

This work presents a comparative study, and an experimental analysis of different types of BASF and Danish Power Systems HTPEM MEAs using polarisation curves and impedance measurements.

High temperature PEM (HTPEM) fuel cells offer a very robust solution of converting the chemical energy available in a hydrogen rich gas, into electricity and heat. The increased operating temperatures of these types of fuel cells offer many advantages, particularly the increased desorption rate of $\mathrm{CO}$ on the anode catalyst and the increased simplicity on system level because of the absence of complex humidification subsystems. This work presents a comparative study, and an experimental analysis of different types of HTPEM MEAs. The study is based on polarisation curve and impedance spectroscopy measurements conducted on BASF and Danish Power Systems MEAs. Measurements show different behaviour and performance in some operating cases, and the different membrane types are compared. For the Danish Power Systems MEAs, catalyst loading has been varied and Pt content in the catalyst layers. Furthermore the effect of different hot press techniques is examined the fuel cell performance. Two different versions of the BASF P2100 MEA has been examined and performance differences are compared between the different fuel cells. The combined efforts of using experimental testing tools such as polarisation curves and detailed modelling can give a better understanding of how different production techniques, fuel cell layer compositions and preparation procedure affect the final performance of a HTPEM fuel cell. 


\section{2 - Oral presentation}

\section{Platinum Pulse Plating on aligned MWCNTs for PEMFC}

Mathias Weiser ${ }^{\mathrm{a}}$, Susanne Dörfler ${ }^{\mathrm{g}}$, Michael Schneider ${ }^{\mathrm{h}}$, Holger Althues ${ }^{\mathrm{i}}$, Alexander Michaelis ${ }^{\mathrm{j}}$, Stefan Kaskel $^{\mathrm{k}}$,

${ }^{\mathrm{a}} \mathrm{TU}$ Dresden, Institute of Materials Science (mathias.weiser@ikts.fraunhofer.de), ${ }^{9}$ Fraunhofer IWS, Winterbergstr. 28, 01277 Dresden, Deutschland, ${ }^{\mathrm{h}}$ Fraunhofer IKTS, Winterbergstr. 28, 01277 Dresden, Deutschland, 'Fraunhofer IWS, Winterbergstr. 28, 01277 Dresden, Deutschland, 'Fraunhofer IKTS, Winterbergstr. 28, 01277 Dresden, Deutschland, 'Fraunhofer IWS, Winterbergstr. 28, 01277 Dresden, Deutschland,

\section{Summary}

The functionalization of the tips of the aligned MWCNTs with platinum nanoparticles by electrochemical pulse plating is presented. The subsequent hot pressing with a Nafion ${ }^{\circledR}$ foil generates a MEA.

The present work reports the successful preparation of a membrane electrode assembly (MEA) based on aligned multi-walled carbon nanotubes (MWCNTs) functionalized with platinum nanoparticles. The outstanding attributes of the MWCNTs are the high specific surface, the well ordered structure, the high electronic conductivity and the hydrophobic surface. Due to these properties MWCNTs are a promising material to improve the performance of polymer electrolyte membrane fuel cells (PEMFC). The preparation of the MEA was carried out in three steps. First the aligned MWCNTs were produced by chemical vapour deposition (CVD) on a nickel foil. Dörfler et al. describe the CVD process in detail[1]. In the second step the tips of the aligned MWCNTs are functionalized with platinum nanoparticles by electrochemical pulse plating. Pulse plating allows the smart adaption of particle size, shape and platinum content by selection of suitable pulse parameters. Based on the electroplating process, all deposited platinum nanoparticles are electrically contacted to avoid inactive nanoparticles. The used aqueous electrolyte based on a potassium tetranitroplatinate (II) salt. Despite the hydrophobic surface of the MWCNTs the addition of wetting agents to the electrolyte was renounced. The wettability at the MWCNT tips increases during the plating process. The formation of functional groups occurs at the surface. Current results present the successful deposition of platinum particles with a size of up to $15 \mathrm{~nm}$ on the tips of the MWCNTs. The deposition zone comprises 2 to $5 \mu \mathrm{m}$ at the top of the $100 \mu \mathrm{m}$ thick MWCNT layer. Additionally experiments are focused on the optimization of the pulse plating parameters to obtain particle sizes in the range of 2 to $5 \mathrm{~nm}$. Final process is the hot pressing of the platinum functionalized aligned MWCNTs with Nafion ${ }^{\circledR}$ to generate a MEA for PEMFC. As result of this preparation the platinum nanoparticles are localized mainly at the interface of polymer and nanotubes. 
33 - Oral presentation

\section{Modeling of Ultrathin Catalyst Layers in Polymer Electrolyte Fuel Cells}

Karen Chan ${ }^{\mathrm{a}}$, Michael Eikerling ${ }^{\mathrm{g}}$,

${ }^{a}$ Simon Fraser University (kchanv@sfu.ca), ${ }^{9}$ Simon Fraser University,

Ultrathin catalyst layers (UTCLS) for polymer electrolyte fuel cells (PEFCs) have shown promising performance at reduced $\mathrm{Pt}$ loading and increased durability. In contrast to conventional catalyst layers, UTCLs are over an order of magnitude thinner $(<1 \mu \mathrm{m})$ and free of ionomer. A major open question in UTCL research is the proton transport mechanism within the ionomer-free UTCL pores. We postulate that protons are drawn into the waterflooded UTCL pores via their electrostatic interaction with the metal surface charge density $[1,2]$. In the present work, we discuss the steady state and impedance variants of a singlepore model of UTCLs. To account explicitly for the metal surface charge, we consider a model system of a water-filled, cylindrical nanopore with charged metal walls. We account for proton and oxygen transport with the Poisson-Nernst-Planck equation and Fick's law of diffusion, oxygen reduction with Butler-Volmer kinetics, and surface charge density at the Pt|solution interface with a Stern model. The major insight of the steady state variant of the model is the importance of electrostatic effects to UTCL performance, essentially neglected in models of conventional catalyst layers. The model shows the UTCL to act as a tunable proton conductor, where the proton concentration and hence reaction current density are dependent on metal|solution charging properties. The implication for UTCL design is that UTCL materials should be selected not only for their intrinsic mass activities and durability, but also for their interfacial charging properties. Simulated polarization curves from the steady state model showed good agreement with experimental data. However, a systematic evaluation of the interplay of electrostatic, kinetic, and mass transport phenomena in UTCL demanded an impedance variant of the model. Based on the general set of transient equations, we have derived analytical impedance expressions and equivalent circuit representations in 4 limiting cases [2]. In collaboration with experimentalists, model validation via systematic impedance measurements of 3M NSTF MEAs is underway.

[1] K. Chan, M. Eikerling, J. Electrochem. Soc. 158, B18 (2011).

[2] K. Chan, M. Eikerling, J. Electrochem. Soc. 159, B155 (2012). 


\title{
34 - Oral presentation
}

\section{Innovative plasma polymerized membranes based on phosphonic acid groups for fuel cell}

\author{
Joelle Bassil ${ }^{a}$, Stéphanie Roualdes ${ }^{b}$, \\ anstitut Européen des Membranes, Université Montpellier 2 (joelle.bassil@iemm.univ-montp2.fr), ${ }^{b}$ nstitut Européen \\ des Membranes, Université Montpellier 2,
}

\section{Summary}

The scope of this study is to demonstrate the feasibility of preparation of phosphonic membranes by PECVD and to correlate PECVD parameters, micro-structural and transport properties of films.

The development of effective and low cost membranes for PEMFC has turned to be a challenge for the membrane community for the last years. Phosphonic acid-based polymers in particular are considered suitable candidates as ionomers due to their amphoteric character, relatively high dielectric constant and less sensitiveness to hydration than Nafion ${ }^{\circledR}$ which give them a good proton conductivity at temperature higher than $80^{\circ} \mathrm{C}$. Among the different techniques suitable for fuel cell membrane preparation, Plasma Enhanced Chemical Vapour Deposition PECVD is particularly promising. PECVD allows the deposition of dense, uniform and defect-free thin films on the surface of a mechanical substrate. Films deposited have a three dimensional structure made up of randomly recombinated fragments of precursor. Depending on PECVD parameters, a wide range of hybrid materials can be obtained. In this study, membranes based on phosphonic acid groups were prepared by PECVD using allyl dimethyl phosphonate as a precursor. The manufactured plasma polymerized membranes were characterized in terms of their micro structural properties, in correlation with the plasma parameters. Scanning electron Microscopy (SEM) showed that plasma membranes deposited on silicon wafer or commercial membrane (mechanical support useful for transport properties investigation) are dense and uniform. Depending on deposition duration and plasma parameters, deposited polymer films exhibit thicknesses in the $0.5-1$ $\mu \mathrm{m}$ range. The chemical composition of films was characterized by X-Ray photoelectron spectroscopy (XPS). The main chemical environments depicted in films are $\mathrm{P}-\mathrm{H}, \mathrm{PH}_{2}-\mathrm{CH}_{3}$, $\mathrm{P}=\mathrm{O}, \mathrm{P}-\mathrm{OH}, \mathrm{P}-\mathrm{O}-\mathrm{CH}_{3}$; decreasing the energetic character of the plasma discharge leads to films richer in $\mathrm{P}-\mathrm{OH}, \mathrm{P}(\mathrm{O}) \mathrm{OH}$ likely favourable to the proton conduction. The phosphonated plasma polymerized membranes were also characterized by thermogravimetry analysis (TGA) under air at a heating rate of $10{ }^{\circ} \mathrm{C} / \mathrm{min}$; phosphonic acid groups could retain water up to $150{ }^{\circ} \mathrm{C}$. This behaviour evidences stability of these membranes in PEMFC operation at high temperature $\left(80-150^{\circ} \mathrm{C}\right.$ ). The proton conductivity of plasma membranes (up to 0.7 $\mathrm{mS} / \mathrm{cm}$ ) was measured at room temperature and $100 \% \mathrm{RH}$ and correlated with synthesis parameters and micro structural properties. 


\title{
35 - Oral presentation
}

\section{Glass flake templated composite PFSA membranes with nanoparticulate inorganic additives and a hierarchical structure}

\author{
Bhawana Agrawal ${ }^{\mathrm{a}}$, Monika Willert-Porada ${ }^{9}$, \\ aUniversity of Bayreuth, Germany (bhawana.agrawal@uni-bayreuth.de), ${ }^{9}$ University of Bayreuth, Germany,
}

PFSA ionomer membranes are widely used for PEM fuel cell application due to their high proton conductivity, low hydrogen permeability and excellent chemical stability. Unfortunately, at operation temperature above $100{ }^{\circ} \mathrm{C}$, PFSA membranes show a significant decrease of ionic conductivity and mechanical stability. While the conductivity decrease is due to dehydration caused by low relative humidity of $<30 \% \mathrm{rH}$ at $\mathrm{T}>100^{\circ} \mathrm{C}$, degradation of stiffness is a temperature effect related to glass transition of PFSA polymer. Attempts to improve properties of PFSA membranes should therefore point in two directions: improvement of ionic conductivity at low relative humidity and increase of stiffness at temperatures of $>0.8 \mathrm{Tg}$, corresponding to $\mathrm{T}>80^{\circ} \mathrm{C}$. For improvement of water retention and mechanical stiffness of PFSA polymers while blending them with hygroscopic oxides, like e.g., $\mathrm{SiO}_{2}$ has been investigated as well as blending with other oxides, e.g., $\mathrm{TiO}_{2}$ as radical scavenger for improvement of chemical stability of the membrane. Most previous work has been devoted to nano-composites, often ignoring the problems of homogeneous distribution of the additive while applying "Re-casting" methods, which are based on an emulsion of PFSA polymer in a solvent mixture, which is prone to agglomeration upon mixing. In the present work we therefore use $\mu \mathrm{m}$-size additives based on commercially available glass flakes, while the nanoscale oxide or other additive is applied as coating to these glass flake macroscopic template. Our attempt is to enable formation of thin confined PFSA polymer films between the glass flake templates, and to adhere the PFSA polymer film to the nano-sized particulate coating present at the surface of the glass-flakes. The resulting composite has a "hierarchical" structure with a 100-10 $\mu \mathrm{m}$ glass-flake template; 1000-100 nm PFSA polymer films attached to 50-5 nm sized Oxide or Fluoride particles, with a 10-1 nm substructure of the phase separated polymer. In the work presented here we describe the properties of such hierarchical structure 3M PFSA polymer composites with certain glass flakes coated with $\mathrm{TiO}_{2}$ and $\mathrm{TiO}_{2}-\mathrm{MgF}_{2}$. The dynamic mechanical properties, thermal stability, water uptake ratio, ionic conductivity in the temperature range up to $120^{\circ} \mathrm{C}$ as well as structural information by XRD, Light scanning microscopy, EDX and SEM are reported. 


\title{
36 - Oral presentation
}

\section{Water Electrolysis using Polymeric Electrolyte Membranes at Elevated Temperatures}

\author{
Erik Christensen ${ }^{\mathrm{a}}$, Martin Kalmar Hansen ${ }^{\mathrm{g}}$, David Aili ${ }^{\mathrm{h}}$, Aleksey Nikiforov ${ }^{\mathrm{i}}$, Chao Pan ${ }^{\mathrm{j}}$, Junyuan $\mathrm{Xu}{ }^{\mathrm{k}}$ \\ Jens Oluf Jensen', Qingfeng Li ${ }^{m}$, Niels J. Bjerrum ${ }^{n}$, \\ ${ }^{a}$ DTU Energy Conversion, Technical University of Denmark (erchr@dtu.dk), ${ }^{9}$ DTU Energy Conversion, Technical \\ University of Denmark, 'DTU Energy Conversion, Technical University of Denmark, 'DTU Energy Conversion, \\ Technical University of Denmark, 'DTU Energy Conversion, Technical University of Denmark, ${ }^{\mathrm{j}}$ DTU Energy \\ Conversion, Technical University of Denmark, 'DTU Energy Conversion; Technical university of Denmark, 'DTU \\ Energy Conversion; Technical University of Denmark, "DTU Energy Conversion, Technical University of Denmark,
}

\section{Summary}

An overview of results from research in water electrolysis based on PEM technology at temperatures above $100^{\circ} \mathrm{C}$, i.e. steam electrolysis and electrolysis of pressurised liquid water, will be given.

Polymeric membranes are subject to an increasing interest for water electrolysis for hydrogen production, in addition to their use in fuel cells. One issue for research and development is an elevated operating temperature of the PEM electrolyser for hydrogen production $(>1000 \mathrm{C})$. In this way the energy efficiency would be expected to be significantly improved because of enhanced electrode kinetics, the decreased thermodynamic energy requirement, and the possible integration of heat recovery. The elevated temperature requires either that the water electrolysis is carried out on steam, or that the working pressure is raised in order to keep the water liquid. An overview of activities within this area in the EU project WELTEMP and the national Danish Project HyCycle will be given. Due to the higher demands to the materials involved caused be the higher temperature key issues were fundamental materials developments, including catalysts, membranes, current collectors, bipolar plates and other construction materials. The activities within proton conducting (acidic) membranes were based on modifications of two types of materials: 1) phosphoric acid doped polybenzimidazole ( $\mathrm{PBI}$ ) membranes, and 2) perfluorinated sulfonated (PFSA) membranes. The PFSA membranes were the most successful. Steam electrolysis at ambient pressure and $120-130^{\circ} \mathrm{C}$ was carried out using PFSA type membranes, but in this case it was necessary to dope them with phosphoric acid in order to maintain their protonic conductivity. Highest performance was obtained using a PTFE reinforced Nafion membrane, pressure 3-7 bar, and at temperatures $120-130^{\circ} \mathrm{C}$. Voltages of $1.65 \mathrm{~V}$ at $1.0 \mathrm{~A} / \mathrm{cm}^{2}$ and $1.85 \mathrm{~V}$ at $2.0 \mathrm{~A} / \mathrm{cm}^{2}$ were oberved. Tantalum coated stainless steel could fulfill the very high demands to corrosion resistance of anodic current collector materials under acidic conditions due to the elevated temperature, and still maintain a low contact resistance. Also alkaline (anion conducting) membranes have been adressed. These allow the use of non-noble metal based, low cost catalysts. Such membrane materials have demonstrated good durability, however still at working temperatures well below $100^{\circ} \mathrm{C}$.

\section{References}

[1] M. K. Hansen, D. Aili, E. Christensen, C. Pan, S. Eriksen, J.O. Jensen, J.H. von Barner, Q. Li and N.J. Bjerrum, Int. J. Hydrogen Energy (2012) in press.

[2] D. Aili, M. K. Hansen, C. Pan, Q. Li, E. Christensen, J.O. Jensen, N.J. Bjerrum, Int. J. Hydrogen Energy 36 (2011) 698 
37 - Invited Oral presentation

\title{
HTPEM System benefits and challenges
}

\author{
Frank Erne ${ }^{\mathrm{a}}$, \\ aelcomax GmbH (frank.erne@elcomax.com),
}

The elcomax group is one of the world's most integrated fuel cell companies. elcomax was founded in 2007 and developed since then an innovative manufacturing process for the MEA - the core component of every fuel cell. This manufacturing process is a platform technology which can be used for all fuel cell types based on metal catalysts and has been successfully demonstrated for DMFC and HTPEM fuel cells. The new method allows significantly reducing the manufacturing cost of MEAs and increasing their durability. In the field of HTPEM elcomax acquired in 2008 the entire HTPEM technology of Sartorius and has since then improved this technology significantly. In 2010 the subsidiary elcore was founded to develop HTPEM systems. With its high CO-tolerance HTPEM could be successfully developed to use widely available fuels like natural gas or LPG. Due to the high operation temperature the produced heat can be efficiently used in combined heat and power applications. Elcore has announced on the Hannover Fair 2012 its newest product Elcore 2400 - a high efficient CHPsystem for use in single homes. The company group elcomax therefore has developed the ability to manufacture fuel cell systems and all fuel cell relevant components starting from raw components like carbon, PTFE, catalyst precursor and PBI-powder. This gives us a unique value chain in the fuel cell industry and makes it possible to design the MEA for the system and operate the system in the best way for the MEA. In this speech I want to show you, which obstacles we had to overcome and which important technology improvements we could achieve. At last I want to give an overview, where we see possibilities for improving the HTPEM technology. 
38 - Invited Oral presentation

\title{
High temperature PEM fuel cell activities at Aalborg University
}

\author{
Søren Knudsen $\mathrm{Kær}^{\mathrm{a}}$, \\ aAalborg University (skk@et.aau.dk),
}

\section{Summary}

The presentation gives an overview of HTPEMFC activities at Aalborg University. A more detailed discussion of methanol fuelled systems is offered including reformer design and fuel cell performance.

The Department of Energy Technology at Aalborg University has been involved in high temperature PEM fuel cell research since year 2005. The activities range from MEA characterization and modelling to stack and system design. The first part of the presentation will give a brief outline of the main contribution made in these areas. The second part will focus on HTPEMFC systems operated on reformed methanol which represent a significant research focus area at Aalborg University. Detailed analyses of methanol reforming based on computational fluid dynamics and experimental characterisation will be presented. The modelling combines fluid dynamics, heat and mass transfer and chemical reactions. Typically there is a trade-off between good conversion of methanol and low carbon monoxide content in the reformate gas. A small slip of methanol lead to lower carbon monoxide content. In order to determine the operating conditions and design of the reformer, the impact of these impurities on the fuel cell performance and degradation has to be mapped. Results from such test will be presented. Test done to date indicate the influence from methanol vapour on the fuel cell is similar to that of carbon monoxide and appears to be reversible as long as the concentration in the gas does not exceed 8-10 \%vol. 
39 - Oral presentation

\title{
EnerFuel High Temperature PEM (HTPEM) Fuel Cell Stacks and System
}

\author{
Tom Pavlik ${ }^{\mathrm{a}}$, Daniel Betts ${ }^{\mathrm{b}}$, \\ ${ }^{a}$ EnerFuel (tom.pavlik@enerfuel.com), ${ }^{b}$ EnerFuel,
}

\begin{abstract}
Summary
EnerFuel will discuss test results for its fuel cell stacks including cell-to-cell voltage and temperature variation, voltage degradation/life,polarization, power density, efficiency, and fuels source
\end{abstract}

EnerFuel manufactures HTPEM fuel cell stacks and systems from less than one to three kilowatts for stationary and transportation applications and for evaluation. EnerFuel was founded in 2004 and has headquarters in West Palm Beach FL, USA. EnerFuel has developed an HTPEM fuel cell stack and associated cooling hardware that has achieved the following characteristics as measured on a $1.2 \mathrm{~kW}$ nominal gross power output stack:

- Incorporates liquid cooling system requiring low parasitic power for coolant pumping (less than 25 watts)

- $\quad$ Less than a $5{ }^{\circ} \mathrm{C}$ temperature variation across the stack

- Less than $10 \mathrm{mV}$ cell-to-cell voltage variation across the stack

- $\quad 155^{\circ} \mathrm{C}$ coolant which may be used for cogeneration or other uses

A proven stack design allows EnerFuel to supply its customers and collaboration partners with several platforms including single and four cell stacks for research and laboratory use, and kilowatt scale stacks and systems for OEMs and system integrators. EnerFuel also supports its customers by developing HTPEMFC solutions to individual specifications. For example EnerFuel has recently provided a three kW ethanol-fueled power plant to a leading automotive OEM and is presently developing a $10 \mathrm{~kW}$ bio-fueled system for an advanced transportation application. 
40 - Oral presentation

\section{Fuel Cell Stacks for HT- and LT-PEM Systems}

Steen Yde-Andersen ${ }^{\mathrm{a}}$, Thibault De Rycke ${ }^{\mathrm{a}}$

aIRD Fuel Cells (sya@ird.dk),

Fuel Cell Stacks have been designed and developed for the different PEM fuel cell technologies. The design has been based on flow field modeling ensuring the required air and fuel flow across the fuel cell MEA using as little energy as possible especially flow fields for mixtures of liquid and gas have been developed. The flow field design has been molded into graphitic bipolar flow plates including circuits for liquid cooling. Equally important has been the design of suitable seals and identification of materials capable of sustaining both an acidic oxidizing and reducing atmosphere at temperatures up to $160-180^{\circ} \mathrm{C}$. HT-PEM stacks have been fabricated in the range from $100 \mathrm{~W}$ to $7 \mathrm{~kW}$ based on these design using commercial available MEAs. A $2 \mathrm{~kW}$ HT-PEM was successfully tested in reformat gas with CO concentrations up to $3 \%$. Combined heat and power units have been developed around $1.5-$ $2.0 \mathrm{~kW}$ LT-PEM stacks operating at $70-75^{\circ} \mathrm{C}$ and $100 \%$ humidified air and pure hydrogen. The systems have been deployed in residential houses in the village Vestenskov on Lolland and tested through a full year. DMFC stacks in the range $0.5-1.0 \mathrm{~kW}$ have been developed together with the required fuel, air and system controls and incorporated into stand-alone power generators. The DMFC systems are feed with 100\% methanol and on-board produced water. The systems are used in-house and in remote areas. The MEAs used in LT-PEM and DMFC stacks have also been developed in parallel with the stack and system development. All these activities have resulted in production lines making fuel cell MEAs, stack components and complete stacks commercial available based on well proven design. 


\title{
41 - Invited Oral presentation
}

\section{Advanced Degradation Studies of High Temperature PEFCs}

\author{
Thomas J. Schmidt ${ }^{\mathrm{a}}$, George Neophytides ${ }^{\mathrm{g}}$, Felix N. Büchi ${ }^{\mathrm{h}}$,
}

${ }^{a}$ Electrochemistry Laboratory, Paul Scherrer Institut (thomasjustus.schmidt@psi.ch), ${ }^{9}$ Electrochemistry Laboratory, Paul Scherrer Institut, "Electrochemistry Laboratory, Paul Scherrer Institut,

The durability of high temperature polymer electrolyte fuel cells (HT-PEFCs) based on phosphoric acid/polymer composites or gels is limited by several processes, mainly found in the degradation of the membrane electrodes assemblies (MEAs) and their components. Membrane thinning and pinhole formation, evaporation of phosphoric acid (both from membrane and catalyst layers), Pt dissolution and carbon corrosion from the catalyst layer[1,2] have been identified as the main degradation modes. Although durability of several 10.000 hours have been demonstrated in laboratory environments, operation under realistic conditions including high operating temperatures of up to $180^{\circ} \mathrm{C}$, temperature cycles and start/stop cycling, combined with operation on highly impure reformates produced by fuel processors remains challenging in order to reach the desired $>40.000$ hours required for stationary CHP HT fuel cell systems. This presentation will summarize the most important degradation modes for HT PEFC MEAs under realistic operation conditions. Insights from results obtained from standard single cell measurements will be presented as well as from operation in segmented cells where both ex-situ and in-situ locally resolved degradation analyses have been performed along the channel of the cell. The combination of findings in the two different cells set-ups provide new understanding of the dominating factors triggering particular degradation modes.

\section{References:}

(1) Mader, J.; Xiao, L.; Schmidt, T. J.; Benicewicz, B. C. In Advances in Polymer Science 216; Springer: Berlin, Heidelberg, 2008, p 63-124.

(2) Schmidt, T. J. In Polymer Electrolyte Fuel Cell Durability; Büchi, F. N., Inaba, M., Schmidt, T. J., Eds.; Springer: New York, 2009, p 199-221. 


\title{
42 - Oral presentation
}

\section{Detection of MEA's flaws in PEMFC: "in-situ" Relaxometry combined with "ex-situ" Infrared Imagery}

\author{
Gilles De Moor ${ }^{\mathrm{a}}$, Corine Bas ${ }^{\mathrm{g}}$, Nicolas Charvin ${ }^{\mathrm{h}}$, Frédéric Niepceron ${ }^{\mathrm{i}}$, Johan André ${ }^{\mathrm{i}}$, Nicolas Caque ${ }^{\mathrm{k}}$, \\ Elisabeth Rossinot ${ }^{1}$, Nicole Albérola ${ }^{\mathrm{m}}$, Lionel Flandin ${ }^{\mathrm{n}}$, \\ aLEPMI-LMOPS CNRS-UMR5279 (gilles.de-moor@univ-savoie.fr), 'EEPMI-LMOPS CNRS-UMR5279, 'LEPMI- \\ LMOPS CNRS-UMR5279, 'LEPMI-LMOPS CNRS-UMR5279, 'Axane, " $A x a n e, ~ ' A x a n e,{ }^{\mathrm{m}}$ LEPMI-LMOPS CNRS-
} UMR5279, "'LEPMI-LMOPS CNRS-UMR5279,

\begin{abstract}
Understanding MEA degradation mechanisms is one of the main issues to improve their durability. However, the complex relationships between laboratory approaches and industrial applications are poorly developed and very challenging to establish. Laboratory "in-situ" tests are indeed mainly performed on single cells with well controlled parameters and focused on specific factors. Although this kind of study is intrinsically limited and hardly allows forecasting what happens in real systems. In contrast feedbacks from real life applications generally focus on macroscopic approaches (Cell voltage, polarization curves, IES...), but fruitful correlation among the data collected is difficult. In conclusion there is a strong need in the fuel cell area for fast, sensitive and reproducible ways to investigate polyelectrolyte degradations. In the present work, fast and robust specific macroscopic tools were used both to characterize and to localize defects, such as pinholes or short-circuits, within the MEA. The identification of defective cells without disassembling a real-life Axane's system was performed in a single step through a passive electrical technique so-called "relaxometry". This powerful passive technique allows a fast characterization of an entire stack (hundreds of MEA in few minutes). It is based on the measurement of electrical properties over time. The principle of the measurement is simple and based on three phases: a forced charging, a current or a voltage is applied to the MEA during a given time; a self discharge, the assembly is held at open-circuit and freely discharges; a forced discharge, to return MEA to an equilibrium state. The self discharge is the most discriminant step. Indeed, a fast relaxation of the potential is directly related to membrane defects such as electronic shortcuts. The flaws were further tracked inside MEA using Infrared Thermography in order to obtain their precise location. This last technique allows pointing out the exact position of flaws inside the MEA with a very high sensitivity. It was possible by calibration to detect pinholes with size close to $75 \square \mathrm{m}$. Consequently, with the numerous data collected (several hundreds of MEA macroscopically analysed), it was shown that every pinhole in the stack could be detected by combining the techniques. The method was also of great help to perform more specific analysis, such as SEM analyses, around flaw areas in order to identify membrane degradation mechanisms after ageing.
\end{abstract}




\title{
43 - Oral presentation
}

\section{Numerical Simulation of the Electrolyte $\left(\mathrm{H}_{3} \mathrm{PO}_{4}\right)$ Loss in HT- PEM Fuel Cells}

\author{
Sebastian Lang ${ }^{\mathrm{a}}$, Johann Timur Kazdal ${ }^{\mathrm{g}}$, Manfred Hampe ${ }^{\mathrm{h}}$, \\ a University of Technology Darmstadt (lang@tvt.tu-darmstadt.de), ${ }^{9}$ University of Technology Darmstadt, "University of \\ Technology Darmstadt,
}

During the last years, there has been a major emphasis on the development of hightemperature $\left(>120^{\circ} \mathrm{C}\right)$ polymer based proton exchange membrane fuel cells (HT-PEMFCs). This effort was mainly driven by the insufficiency of the properties of perfluorinated sulfocationic membrane materials like e.g. Nafion ${ }^{\circledR}$. Initial work on Polybenzimidazole (PBI) based membranes using phosphoric acid as electrolyte has shown that many of the requirements for high temperature operation can be satisfied by this membrane system. However, some of the problems with using PBI in combination with phosphoric acid for fuel cell membranes include: insufficient phosphoric acid loading, phosphoric acid evaporation and leaching as well as condensative chain polymerization of the phosphoric acid. The mechanisms mentioned afore all end in a decreased ionic conductivity and hence a performance loss of the fuel cell. Our ongoing research focuses on the investigation of the phosphoric acid loss in HT-PEMs. To identify the significance of each of those degradation mechanisms a thorough experimental and theoretical analysis had to be done. The experiments that we have carried out include the measurement of the vapor liquid phase equilibrium and the diffusion coefficient of water and phosphoric acid also in the presence of $\mathrm{m}$-PBI. We have also gathered structural information about phosphoric acid by the use of NMR and ATR-IR spectroscopy. Also electrochemical impedance spectroscopy and IV characteristic measurements have intensively been performed over a period of more than 3000 hours with a single cell in dependence of various operation parameters like e.g. humidity. Especially the latter experimental results are the basis for the validation of a numerical simulation (FEM) that gives a deeper understanding of the degradation mechanisms causing a phosphoric acid loss in HT-PEM fuel cells. The results indicate that acid evaporation plays a minor role for the loss of electrolyte. Acid leaching was identified as the major loss mechanism, probably caused by recurrent swelling and shrinking of the electrolyte in the porous regimes of the MEA system. The condensative chain polymerization of the phosphoric acid is reversible and can be expected to play a bigger part only at temperatures above $180^{\circ} \mathrm{C}$. FEM simulations indicate that besides the decreased ionic conductivity of the membrane also the maldistribution of the phosphoric acid leads to a significant drop in performance. 


\title{
44 - Oral presentation
}

\section{Theory of Ionomer Aggregation in Polymer Electrolyte Membranes}

Pierre-Éric Melchy ${ }^{\mathrm{a}}$, Michael Eikerling ${ }^{\mathrm{g}}$,

${ }^{a}$ Simon Fraser University, Department of Chemistry, Burnaby, BC, Canada (pmelchy@sfu.ca), ${ }^{9}$ Simon Fraser University, Department of Chemistry, Burnaby, BC, Canada,

\begin{abstract}
Chemical degradation of ionomer molecules causes continuous changes in microstructural organization and transport properties of polymer electrolyte membranes (PEMs). The associated detrimental changes in electrochemical performance, mechanical robustness and lifetime of polymer electrolyte fuel cells are a major concern of fuel cell developers.1-2 Ionomer degradation mainly results from chemical attack by radicals, which are formed during fuel cell operation at metal ions or platinum deposits in the membrane. Radical reactions lead to the shortening of hydrophobic backbones or the loss of acid-terminated side-chains. These chemical processes transform the thermoelastic and electrostatic properties of the membrane. A systematic understanding of ionomer aggregation and corresponding ion distributions is vital to establish the link between primary chemical architecture, affected by degradation, and the changes in elastic, electrostatic and transport properties of the PEM. In this talk, we will present a physical theory of ionomer aggregation in water. It accounts for polymer branching and charge distribution effects due to side-chains with ionisable head groups. We formulate a description of ionomers as branched chains of beads and minimise the free energy to calculate the equilibrium structures. 3 The free energy expression accounts for electrostatic and elastic contributions. The latter is a classical Hookean term between adjacent beads; the former can assume a dipolar or a screened Coulombic form. We study the formation of stable ionomer conformations and aggregates as a function of the length of the backbone and of side-chains, of the distribution of side-chains along the backbone, and of the ionomer concentration in solution. Resulting structures are analysed in view of the persistence length of ionomer molecules and fibrillar ionomer aggregates, the shape of aggregates, 4 the number of ionomer molecules per aggregate and the distribution of ionic groups at the surface of aggregates.
\end{abstract}

[1] R. Borup et al., Chem. Rev. 107, 3904 (2007)

[2] F. De Bruijn et al., Fuel Cells 8, 3 (2008); C. Chen and T. Fuller, Polym. Deg. Stab. 94, 1436 (2009).

[3] A. Dobrynin and M. Rubinstein, Prog. Polym. Sci. 30, 1049 (2005).

[4] A. Ioselevitch et al., J. Phys. Chem. B 108, 11953 (2004). 


\title{
45 - Oral presentation
}

\section{Evaluation of Platinum Band Formation in PEM Fuel Cells}

\author{
Marianne Rodgers $^{\mathrm{a}}$, David A. Cullen ${ }^{\mathrm{g}}$, Leonard J. Bonville ${ }^{\mathrm{h}}$, Darlene K. Slattery ${ }^{\mathrm{i}}$, James M. Fenton ${ }^{\mathrm{j}}$,
}

a University of Central Florida-Florida Solar Energy Center (mrodgers@fsec.ucf.edu), ${ }^{9}$ Oakridge National Laboratory, hUniversity of Central Florida-Florida Solar Energy Center, 'University of Central Florida-Florida Solar Energy Center, 'University of Central Florida-Florida Solar Energy Center,

One of the main sources of membrane degradation is radical attack. These radicals are formed where $\mathrm{Pt}, \mathrm{H} 2$, and $\mathrm{O} 2$ are present. Once formed, the radicals attack the membrane, shortening the cell life, and generating large performance losses. Mitigation of chemical degradation will significantly enhance the lifetime of membranes. However, in order to decrease chemical degradation, the chemical processes that contribute to membrane failure must be better understood. The conditions for radical formation are generally met at the anode and cathode, where reactants diffusing through the membrane can react on the surface of the Pt catalyst. In addition, high potentials at the cathode result in the formation of $\mathrm{Pt}$ ions, which can then migrate into the membrane until they are reduced by hydrogen. Over time, the number and size of Pt particles increases within the membrane, forming a Pt band, where significant radical generation occurs, resulting in severe membrane degradation. In situ Pt formation in the membrane is not adequately understood, nor is the impact of variables such as nanoparticle size and distribution. These add to the difficulty of understanding the degradation effect of the Pt particles on membrane. In this project, the properties of Pt within the membrane are evaluated and related to membrane degradation. Membranes have been ex situ impregnated with different amounts of $\mathrm{Pt}$ and then tested for $100 \mathrm{~h}$ in a fuel cell under open circuit voltage, at $90{ }^{\circ} \mathrm{C} / 30 \%$ relative humidity. Preliminary results have shown that the highest degradation was observed with the membrane containing $10 \mathrm{~mol} \% \mathrm{Pt}$, with fluoride emissions of the same magnitude of those seen with catalyst coated CCMs containing Pt/C. Membranes containing 0,30 , and $50 \mathrm{~mol} \% \mathrm{Pt}$ resulted in very low fluoride emission. Transmission electron microscopy allowed examination of the size, shape and distribution of Pt particles in the membranes before and after testing. By correlating the TEM and electrochemical measurements, we can improve our understanding of the size, shape, and distribution effects on membrane degradation without the added complication of radical contributions arising from the Pt catalysts in the electrodes. 


\title{
46 - Invited Oral presentation
}

\section{Recent Research of the PBI/PA System as a Proton Conductor in Electrochemical Systems}

\author{
Robert Savinell $^{a}$, Jesse Wainright ${ }^{g}$, Tyler Petek ${ }^{h}$, \\ ${ }^{\mathrm{a}}$ Casa Western Reserve University (rfs2@case.edu), ${ }^{\mathrm{g}}$ Case Western Reserve Univeristy, ${ }^{\mathrm{h}}$ Case Western Reserve \\ University,
}

PBI doped with phosphoric acid membranes function as a proton conductor at elevated temperatures and has enabled the development of high temperature PEM fuel cells and is being explored for other technologies such as for hydrogen purification and pumping. It could find further applications in electrochemical sensors and electrochemical synthesis cells as well. Unfortunately this proton conducting membrane is not optimum for ORR because of acid anion adsorption on catalyst surfaces. Furthermore, the mechanical properties of the membrane could be improved for operating devices, and a better understanding of the transport mechanism would help understand operational limits and durability of the membrane. It this presentation I plan to talk about some of the current research my group has engaged upon related to the PBI/PA system. I will describe our experiments and results of PBI/PA in a hydrogen pump cell. Besides the practical implications of hydrogen pump technology, this system also serves as a way to perhaps better understand the proton conducting mechanism in this system. I will discuss some of our recent thinking on the role of $\mathrm{PBI}$ on phosphoric acid conduction and acid migration within the film. I will also report on some results of a kapton/PBI/PA composite membrane film that is intended to enhance the mechanical properties of a thin membrane film 


\title{
47 - Oral presentation
}

\section{Nano-structured Aromatic lonomers for PEMFC}

\author{
Cristina lojoiu $^{\mathrm{a}}$, Luca Assumma ${ }^{\mathrm{g}}$, Regis Mercier $^{\mathrm{h}}$, \\ aLEPMI, CNRS-Grenoble INP-Universite de Savoie-U J F (cristina.iojoiu@lepmi.grenoble-inp.fr), ${ }^{9}$ LEPMI, "hEPMI,
}

\section{Summary}

New aromatic copolymers were synthetized and characterized. The thermal, mechanical and electrochemical properties of membranes performed were investigated and correlated with the membranes morphology

The proton conducting membrane is a key component in proton exchanges membrane fuel cell (PEMFC). To assure high performance PEMFC the polymer membrane requires good mechanical properties, low gas permeability, good dimensional stability and good chemical and electrochemical stability in fuel cell operating conditions. Currently, the perfluorosulfonated ionomers such as Nafion ${ }^{\circledR}$ membrane remains the reference materials for fuel cell application in terms of performance and stability. The high level of proton conductivity even at low water content has to be attributed to favorable nanoscale morphology and to the very high acidity of fluorosulfonate groups. However their drawbacks such as low conductivity and weak mechanical strength at temperature above $90^{\circ} \mathrm{C}$ make necessary the development of new materials capable to resist at temperature exceeding $100^{\circ} \mathrm{C}$. Thus the sulfonated aromatic polymers have been largely studied as polymer alternative to the Nafion. These polymers have good chemical, electrochemical, thermo-mechanical stability, but the proximity of ionic function grafted directly to the main chain coupled with the need of high CEC (cation echange capacity) cause extensive water uptake and consequently a dramatic loss of mechanical strengths. This behaviour renders this kind of membranes unsuitable for practical PEM applications. To solve this issue few solutions have been proposed, as for example to induce a phase separation between hydrophilic domains containing acidic function and hydrophobic domains composed of aromatic polymer chain. One promising approaches to obtain aromatic polymer having nano- phase separation with co-continues conducting channels concern the synthesis of block copolymers in which sulfonic acidic groups are concentrated in one of the block along polymer chain. This work deals the synthesis and characterization of new block copolymers containing hydrophilic blocs, functionalised with a perfluorinated acid, and hydrophobic blocs which are partially fluorinated. The polymer main chain was performed by polycondensation reaction. The acidic functions were grafted onto the polymer in two steps: bromination and coupling Ullman reaction. The super acidity of acidic function combined with a high flexibility of the spacer and the presence of fluorinated aromatic rings on main chain allow the nano-phase separation. Different copolymers with different lengths of hydrophobic-hydrophilic bloc were investigated. 
48 - Oral presentation

\section{A simply synthesized procedure of sulfonated poly(arlyene ether) type polymers for polymer electrolyte membrane fuel cells}

Young-woo Choi ${ }^{\mathrm{a}}$, Mi-Soon Lee ${ }^{\mathrm{g}}$, Tae-Hyun Yang ${ }^{\mathrm{h}}$, Chang-Soo Kim ${ }^{\mathrm{i}}$, Yang-Hoon Kim ${ }^{\mathrm{j}}$,

${ }^{\mathrm{a} K o r e a}$ Institute of Energy Research (cozmoz67@kier.re.kr), ${ }^{9}$ Korea Institute of Energy Research, ${ }^{\text {h}}$ Korea Institute of Energy Research, 'Korea Institute of Energy Research, 'Chungbuk National University,

Most researchers have followed the conventional polymerization method to prepare sulfonated poly(arylene ether) sulfones (SPAES), what is typically called Friedel-Craft polymerization method, for the application to polymer electrolyte membrane fuel cells. However it is very complicated and difficult to synthesize reproducible high molecular sulfonated polymers because its procedure needs an azotropic solvent such as toluene and cyclohexane to dehydrate produced water with a main solvent such as DMAc, DMF, and NMP for polymerization. Furthermore, very high temperatures are critically required to synthesize the polymers with $\mathrm{Cl}$-ended monomers when NMP is used as a main solvent. In order to solve these drawbacks, we have developed a totally simplified and reproducible polymerization procedure without the azotropic solvents to synthesize SPAES. The polymers prepared by the new procedure was characterized and compared to conventionally prepared SPAES. 
49 - Oral presentation

\title{
Aromatic Polyethers for High Temperature Polymer Electrolyte Membrane Fuel Cells (HT-PEMFCs) operating above $180^{\circ} \mathrm{C}$
}

\author{
Aikaterini Andreopoulou $^{\mathrm{a}}$, Christina Morfopoulou ${ }^{\mathrm{g}}$, Maria Daletou ${ }^{\mathrm{h}}$, Konstantinia Papadimitriou $^{\mathrm{i}}$, Ioannis \\ Kalamaras ${ }^{j}$, Stylianos Neophytides ${ }^{k}$, Joannis Kallitsis ${ }^{\prime}$, \\ anstitute of Chemical Engineering Sciences, FORTH/ICE-HT, Patras 26504, Greece \\ (kandreop@chemistry.upatras.gr), ${ }^{9}$ Institute of Chemical Engineering Sciences, FORTH/ICE-HT, Patras 26504 , \\ Greece, "Institute of Chemical Engineering Sciences, FORTH/ICE-HT, Patras 26504, Greece, 'Advent Technologies \\ S. A., Patras Science Park, 26504, Patras, Greece, I'Institute of Chemical Engineering Sciences, FORTH/ICE-HT, \\ Patras 26504, Greece, ${ }^{k}$ Institute of Chemical Engineering Sciences, FORTH/ICE-HT, Patras 26504, Greece, \\ 'Department of Chemistry, University of Patras, 26500 Patras, Greece,
}

Polymer electrolyte membrane fuel cells (PEMFCs) are promising clean power sources based on hydrogen. Particularly High Temperature PEMFCs (HT-PEMFCs) operating above $180^{\circ} \mathrm{C}$, can tolerate high amounts of $\mathrm{CO}$ enabling the use of reformed hydrogen together with higher catalyst's utilization, simplified design, and reduced cost. Polymer electrolytes for high temperature MEAs must posses special properties in order to withstand the harsh conditions during fuel cell operation, thus current research focuses on the development of polymers with tailored made properties such as improved dopant retention and high proton conductivities $(\sim 10-1 \mathrm{Scm}-1)$ at temperatures close to 200oC.[1] Herein, novel aromatic copolyethers bearing main chain polar pyridine units and side functional groups are presented.[2,3,4] Different side functional groups like carboxylic acid, sulfonic acid and double bond moieties have been used and their influence on the membrane properties and single cell performance has been studied. The carboxylic acid or double bond bearing copolymers were subjected to chemical cross-linking either directly during their doping procedure in phosphoric acid or with the use of cross-linking agents. The effect of the cross-linking on the membranes' properties was thoroughly studied. Finally, membrane electrode assemblies (MEAs) were constructed from selected cross-linked membranes and tested in single cells operating at high temperatures up to $230 \circ \mathrm{C}$. The stable performance for more than $500 \mathrm{~h}$ at $210 \mathrm{oC}$ demonstrates the potential use of these materials as electrolytes for high temperature PEM fuel cells and especially for internal reforming alcohol fuel cells.[3,5]

\section{References}

1. J. K Kallitsis et.al. Polym. Int., 2009, 58, 1226; M. K. Daletou, et.al. Modern Aspects of Electrochemistry, Number 49, p. 301, Ed. C. Vayenas et al., Springer, New York, (2010).

2. K. D. Papadimitriou, et.al. Macromolecules 2011, 44, 4942.

3. C. Morfopoulou, et.al. J. Polym. Sc. Part A: Polym. Chem. 2011, 49, 4325.

4. I. Kalamaras et.al. Fuel Cells 2011, 11, 921.

5. I. Kalamaras et.al. J. Membr. Sci., http://dx.doi.org/10.1016/j.memsci.2012.04.057.

\section{Acknowledgement}

Financial support of this work from the European Commission ( $\mathrm{FCH}-\mathrm{JU})$ through the program "Understanding the Degradation Mechanisms of Membrane-Electrode-Assembly for High Temperature PEMFCs and Optimization of the Individual Components", DEMMEA FCH-JU 245156 (2010-2012), is greatly acknowledged. 
50 - Oral presentation

\title{
Kinetic Study on the Doping Level of ABPBI Membrane
}

\author{
Fang Liu ${ }^{\mathrm{a}}$, Werner Lehnert ${ }^{\mathrm{g}}$, Detlef Stolten ${ }^{\mathrm{h}}$,
}

${ }^{a}$ Institute of Energy and Climate Research - Fuel Cells (IEK-3), Forschungszentrum Jülich GmbH, 52425 Jülich, Germany (f.liu@fz-juelich.de), Institute of Energy and Climate Research - Fuel Cells (IEK-3) Forschungszentrum Jülich $\mathrm{GmbH}$, Institute of Energy and Climate Research - Fuel Cells (IEK-3). Forschungszentrum Jülich GmbH,

\section{Summary}

In a summary, the investigated doping process of $A B P B I$ membranes in concentrated $\mathrm{H}_{3} \mathrm{PO}_{4}$ can be regard as an endothermic reaction with the activation energy of $90 \mathrm{~kJ} / \mathrm{mol}$ at temperatures above $70^{\circ} \mathrm{C}$.

As a solid membrane, poly [2-5-benzimidazole] (ABPBI) gained high attention for high temperature polymer electrolyte fuel cells. The current work deals with the kinetic of the doping process of $\mathrm{ABPBI}$ membrane in phosphoric acid. These membranes were doped in concentrated phosphoric acid in a temperature range between 25 and $130{ }^{\circ} \mathrm{C}$. The doping level increased significantly at the beginning and then slightly until approaching equilibrium. The equilibrium doping level increased with doping temperature. The kinetic data of the acid doping approach was analyzed with kinetic models of pseudo-first-order and pseudo-secondorder which are described in details elsewhere [1]. For the doping test at $25^{\circ} \mathrm{C}$, the kinetic fits to the pseudo-first-order model, and similar results were obtained by [2]. While at the temperature from 70 to $130{ }^{\circ} \mathrm{C}$, the kinetic data follows a pseudo-second-order response. Furthermore, the initial absorption rate increases with the doping temperature up to $130{ }^{\circ} \mathrm{C}$.. In addition, activation energy of the doping was calculated with the Arrhenius equation based on the kinetic data for the temperature range of $70-110{ }^{\circ} \mathrm{C}$. The activation energy reaches $90 \mathrm{~kJ} / \mathrm{mol}$, which indicates that the doping approach can be considered as a complex of physical and chemical adsorption. 
51 - Poster session

\section{Performance of a phosphonated hydrocarbon ionomer in the fuel cell cathode catalyst layer}

$\underline{\text { Rakel Wreland Lindström }}{ }^{\mathrm{a}}$, Alejandro Oyarce ${ }^{\mathrm{g}}$, Luis Guerrero Aguinaga ${ }^{\mathrm{h}}$, Diego Ubeda ${ }^{\mathrm{i}}$, Mark Ingratta ${ }^{\mathrm{j}}$, Patric Jannasch ${ }^{k}$, Göran Göran Lindbergh',

${ }^{a}$ Applied Electrochemistry, KTH - Royal Institute of Technology (rakel2@kth.se), ${ }^{9}$ Applied Electrochemistry, KTH Royal Institute of Technology, ${ }^{\text {h} A p p l i e d ~ E l e c t r o c h e m i s t r y, ~ K T H ~-~ R o y a l ~ I n s t i t u t e ~ o f ~ T e c h n o l o g y, ~ ' A p p l i e d ~}$ Electrochemistry, KTH - Royal Institute of Technology, 'Department of Chemistry, Polymer and Materials Chemistry, Lund University, ${ }^{k}$ Department of Chemistry, Polymer and Materials Chemistry, Lund University, 'Applied Electrochemistry, KTH - Royal Institute of Technology, Stockholm,

Inexpensive and environmentally friendly electrolyte polymers that can be operated at higher temperatures and at drier conditions are highly interesting for PEM fuel cells for automotive, portable power and stationary electricity generation applications. In this study an ionomer based on polysulfone grafted with poly(vinylphosphonic acid) (PSUgPVPA) in the cathode $\mathrm{Pt} / \mathrm{C}$ catalyst layer $(\mathrm{CL})$ was electrochemically characterized and compared to Nafion ${ }^{\circledR}$. The performance at different levels of humidity at $80^{\circ} \mathrm{C}$ was evaluated by polarization, cyclic voltammetry and electrochemical impedence spectroscopy. The results show that the performance of the PSUgPVPA based cathode $\mathrm{CL}$ is comparable to that of Nafion at $80{ }^{\circ} \mathrm{C}$ using $\mathrm{O}_{2}$ in the cathode and $100 \%$ relative humidity $(\mathrm{RH})$ but with some instabilities. However, at drier conditions significant losses of performance for the PSUgPVPA-based cathode was observed, concomitant to a reduced electrochemical surface area. The lower performance at low humidity is concluded to be due to a combination of lower proton conductivity and poorer wettability of the ionomer at lower $\mathrm{RH}$ or due to ionomer interference with oxygen reduction reaction. 


\title{
Temperature Dependence of the States of Water Clusters and Proton Conductivity for Perfluorinated and Hydrocarbon Ionomers for Fuel Cells
}

\author{
M. A. Barique ${ }^{\mathrm{a}}$, A. Ohira ${ }^{\mathrm{g}}$, S. Seesukphronrarak ${ }^{\mathrm{h}}$, \\ ${ }^{a}$ Fuel Cell Cutting-Edge Research Center Technology Research Association (ma.barique@fc-cubic.or.jp), ${ }^{9}$ Research \\ Institute for Ubiquitous Energy Devices, AIST, Midorigaoka, Ikeda, Osaka, ${ }^{\mathrm{h}}$ Fuel Cell Cutting-Edge Research Center \\ Technology Research Association,
}

\section{Summary}

Hydrated morphology of PF and $\mathrm{HC}$ ionomers at elevated temperature were investigated by SAXS and FTIR in details and the dependent of proton conductivity was correlated with the changed morphology.

This paper presents the effects of temperature on the physical states of water clusters in the electrolyte ionomers, the changes in the morphology and their relation with the proton conductivity for PF (Nafion, Aquivion) and HC (SPES) ionomers. Attention was focused especially to elevated temperature $\left(80-120^{\circ} \mathrm{C}\right.$.) region. The changes in the sharpness of polymer/water interface deduced from 2D SAXS patterns. Porod analysis suggested segregated hydrophobic/hydrophilic phases with very sharp boundaries (slope value of -4) with well-developed ionic clusters at around $80^{\circ} \mathrm{C}$. and after that the clusters started to disperse. But for Aquivion no phase separation occurred up to $100^{\circ} \mathrm{C}$. The results suggested that for Nafion, due to the local motion of main-chain and the side-chain the free energy become maximum and the ion-water cluster become well-developed around $80^{\circ} \mathrm{C}$., but above that due to the increased movement of matrix and water, weakly-bonded waters attached to the cluster gradually disperse at elevated temperature. But for Aquivion, as the $\mathrm{Tg}$ is $110^{\circ} \mathrm{C}$., so no motion of main or side-chain occurred. The states and types of waters were investigated by FTIR. For Nafion a broad band at $1730 / \mathrm{cm}$ (bending of protonated water) was observed. With increasing $\mathrm{RH}$, a new band at $1640 / \mathrm{cm}$ (from free water) was appeared. Further increase of $\mathrm{RH}$ and temperature, the protonated water band became very broad, but the band from free water gradually became intensified and sharper. For Aquivion protonated water band at $1720 / \mathrm{cm}$ and the free water band at $1638 / \mathrm{cm}$ were appeared. However, for SPES though very broad band from free waters at $1642 / \mathrm{cm}$ was observed, but no band from protonated water could be detected. The reasons for all the above phenomena were suggested as the cause of the difference in the freedom of the motion of matrix molecules, the movement of free waters and the interaction between polymer and waters in the ionomers. The proton conductivity for PF and $\mathrm{HC}$ ionomers at elevated temperature did not decrease, rather increased, which is interpreted as the development of co-continuous networks of free waters in the whole ionomer.

[This work was supported by the Ministry of Economy, Trade and Industry (METI) and The New Energy and Industrial Technology Development Organization (NEDO), Japan] 


\title{
How Water Uptake and Temperature Affects Proton Conductivity of Poly(vinylidene fluoride-co- chlorotrifluoroethylene)-g-poly(styrene sulfonic acid) and Its Blends with PVDF
}

\author{
Mads Møller Nielsen ${ }^{\mathrm{a}}$, Ami C. C. Yang ${ }^{\mathrm{g}}$, Katja Jankova ${ }^{\mathrm{h}}$, Søren Hvilsted ${ }^{\text {', Steven Holdcroft }}{ }^{\mathrm{j}}$, \\ ${ }^{a}$ Department of Chemical and Biochemical Engineering, Danish Polymer Centre, Technical University of Denmark \\ (mon@kt.dtu.dk), ${ }^{9}$ Department of Chemistry, Simon Fraser University, ${ }^{h}$ Department of Chemical and Biochemical \\ Engineering, Danish Polymer Centre, Technical University of Denmark, 'Department of Chemical and Biochemical \\ Engineering, Danish Polymer Centre, Technical University of Denmark, ${ }^{\mathrm{j}}$ Department of Chemistry, Simon Fraser \\ University,
}

PerFluoroSulfonic Acids (PFSA) currently predominate as commercial state-of-the-art low temperature Proton Exchange Membranes (PEM), yet they suffer from especially high cost. Hence research to find alternatives is ongoing as large-scale commercialization of hydrogen powered PEM fuel cell cars in 2015 is approaching [1]. The current study is a continuation of the previously presented work by Holdcroft et al. [2-3]. Post-sulfonated (s) poly(vinylidene fluoride-co-chlorotrifluoroethylene)-g-polystyrene (P(VDF-co-CTFE)-g-sPS) at three different graft lengths are blended with PVDF to contain SPS volume fractions similar to that of a reference $\mathrm{P}(\mathrm{VDF}-\mathrm{CO}-\mathrm{CTFE})$-g-SPS with a different graft density and graft length. Proton conductivities are measured at 55-95\% Relative Humidity $(\mathrm{RH})$ and $25-80{ }^{\circ} \mathrm{C}$, and water uptake is followed by dynamic vapor sorption. P(VDF-co-CTFE)-g-sPS show stronger dependence on both $\mathrm{RH}$ and temperature than benchmark PFSA Nafion ${ }^{\circledR}$, with superior conductivities by up to a factor of two at $95 \% \mathrm{RH}$. 


\title{
Locally confined membrane modification preventing edge- break and gas inlet/outlet area degradation during fuel cell operation
}

\author{
Dirk Henkensmeier ${ }^{\mathrm{a}}$, N. Nambi Krishnan ${ }^{\mathrm{g}}$, Hyoung-Juhn Kim ${ }^{\mathrm{h}}$, Suk-Woo Nam ${ }^{\mathrm{i}}$, \\ ${ }^{\mathrm{a}}$ Korea Institute of Science and Technology (henkensmeier@kist.re.kr), ${ }^{9}$ Korea Institute of Science and Technology, \\ ${ }^{h}$ Korea Institute of Science and Technology, 'Korea Institute of Science and Technology,
}

The membrane electrode assembly (MEA) is the main component of a proton exchange membrane fuel cell (PEMFC) and the membrane is the key determinant of the MEA durability. Especially aromatic hydrocarbon based membranes often show cracks at the interface between the catalyst coated active and uncoated non-active area, where the stresses are maximal during expansion and contraction.[1] Other sensitive areas are the gas inlet and outlet areas, which are known to degrade faster than the main area, due to fuel starvation, high and low humidity etc. Without stabilisation A membrane prepared by solution casting of SPAES 50 (Aquafone, Yanjin Technology), a polysulfone based membrane, which has a high IEC $(2.1 \mathrm{mmol} / \mathrm{g})$ and swells strongly in water, failed within 50 hours operation in the fuel cell. Disassembling of the cell revealed that the membrane was strongly degraded at the cathode inlet and anode outlet. Furthermore, one of the four edges between active and in-active area had a long crack. Stabilised Membranes By heating the sensitive membrane areas to $180^{\circ} \mathrm{C}$ for 24 hours, desulfonation and/or crosslinking was induced. While this time is too long to be industrially attractive, it should be possible to reduce the reaction time by increasing the temperature and changing to an inert atmosphere. As expected, the treated areas showed a slight discoloration, reduced IEC values, reduced water uptake and increased dimensional stability.[2] Resulting membrane electrode assemblies were tested in the fuel cell for 50 hours and delivered a stable performance. Disassembled MEAs showed no signs of degradation.

\section{References}

1. B. Bauer, D. J. Jones, J. Rozière, L. Tchicaya, G. Alberti, M. Casciola, L. Massinelli, A. Peraio, S. Besse, E. Ramunni, J. New Mater. Electrochem. Syst., 393 (2000).

2. D. Henkensmeier, N. Nambi Krishnan, H.-J. Kim, J. H. Jang, E. Cho, I.-H. Oh, S.-A. Hong, S.-W. Nam, T.-H. Lim, KR 10-2011-0117042. 
55 - Poster session

\title{
Proton Exchange Membranes Reinforced by Impregnation with Hydrocarbon Polymer Electrolyte for PEM Fuel Cells
}

\author{
Nayoung Kim ${ }^{\mathrm{a}}$, Yong Cheol Shin ${ }^{\mathrm{g}}$, Moo-seok Lee ${ }^{\mathrm{h}}$, Dong Hoon Lee ${ }^{\mathrm{i}}$, \\ ${ }^{a}$ Kolon Central Research Park (cutenayoung@kolon.com), ${ }^{9}$ Kolon Central Research Park, ${ }^{\text {h}}$ Kolon Central Research \\ Park, 'Kolon Central Research Park,
}

\section{Summary}

We have prepared reinforced hydrocarbon polymer electrolyte membranes for PEM fuel cells. Reinforced PEMs exhibited higher physical properties than neat PEMs, without sacrificing membrane performance.

Recently, proton exchange membrane (PEM) fuel cells have been widely considered as one of alternative devices for energy conversion as a clean and efficient for transportation and many other applications. The material of polymer electrolyte used in current PEM fuel cells is commonly a hydrated sulfonic acid functionalized polymer. Because of the harsh conditions in operating fuel cells, hydrolytic, thermo-oxidative, and electrochemical stabilities are key issues in the choice of the polymer electrolyte. Perfluorosulfonic acid polymer membranes such as Nafion are the most widely used polymer electrolyte membranes for fuel cells because they give high proton conductivity and good chemical, mechanical and thermal stability. Nafion membranes are featuring superior stability compared to most hydrocarbonbased membranes. But (1) their high fuel crossover, (2) their low proton conductivity at elevated temperatures and low degrees of humidification, (3) low demensional stability and their poor mechanical stability in Wet/Dry condition, and (4) the appearance of highly reactive oxidizing radicals are still severe disadvantages of these membranes. In this study, we have prepared reinforced polymer electrolyte membranes for proton exchange membrane fuel cells. The reinforced PEMs are impregnated with hydrocarbon-based polymer electrolyte. Here, nano-structured substrate was introduced, in order to improve the mechanical stability (i.e. dimensional change and water uptake). Consequently, reinforced PEMs exhibited higher physical properties than neat PEMs, without sacrificing membrane performance. The obtained results suggested that the reinforced polymer electrolyte membranes could be utilized as an alternative proton exchange membrane for fuel cell applications.

\section{Acknowledgement}

This work was supported by the WPM(World Premium Material) of the KIET grant funded by the Ministry of Knowledge Economy, Republic of Korea (No. 10037748) 
56 - Poster session

\title{
A Study on Heteropolyacid-Sulfonated Hydrocarbon-based hybrid Membrane
}

\author{
Akihiro Ohira ${ }^{a}$, Surasak Seesukphron ${ }^{9}$, \\ ${ }^{a}$ National Institute of Advanced Industrial Science and Technology (AIST) (a-oohira@aist.go.jp), ${ }^{9}$ FC-Cubic TRA,
}

\begin{abstract}
Summary
Although further improvement of matrix phase and additives should be needed heteropolyacid hybrid membrane with hydrocarbon-type polymer would be promising to improve their properties.
\end{abstract}

The proton exchange membrane (PEM), the key material for the operation of a proton exchange membrane fuel cell (PEMFC), have much been received attraction as promising for clean power sources in portable and stationary electronic application. Currently, perfluorosulfonic acid (PFSA) ionomer are widely used as the PEM in PEMFC because of their good mechanical properties and high oxidative stability as well as high proton conductivity. However, high cost, loss of proton conductivity at high temperature and low humidity, and relatively high gas permeability have limited PFSA membranes for further commercial application. Therefore, the development of an alternative non-perfluorinated polymeric materials have been extensively investigated in many research groups to get high proton conductivity and to apply for the condition at high temperatures with lower fuel crossover. More recently, trend is developing the hybrid organic/inorganic composite membranes fuel cell applications, because many of the inorganic materials enhance proton conductivity, water retention, and mechanical strength at high temperatures. This paper presents a study on structure and physical property of heteropolyacid-sulfonated hydrocarbon-based hybrid membrane. Attention was focused especially to effect of matrix phase on the heteropolyacid additives to improve the proton conductivity without mechanical failure. We here prepared SPEEK and SPES containing triptycene groups (PES-X-TPD) as matrix for hybrid membrane. The general properties of the obtained membranes such as water uptake and proton conductivity were investigated. The proton conductivity and water uptake for the SPEEK (IEC:1.56) and for the hybrid membranes with 1, 5, and 10 wt\% HPA (heteropoly acid: 12-silicotunstic acid (HSiW) were measured as a function of humidity (10$95 \%)$ at $80^{\circ}$ From the results, we found that all the doped hybrid membrane outperform the undoped control membrane at all the $\mathrm{RH}>40 \%$. At $80 \% \mathrm{RH} 10 \%$ doping of HSiW, proton conductivity reached to twice when compared to the control membrane. For the water uptake result, interestingly, it can be seen that the water uptake decreased with increase in HSiW ratio. Dimensional stability, tolerance of water extraction and mechanical property with different matrix polymers will also be discussed.

This work was supported by the Ministry of Economy, Trade and Industry (METI) and The New Energyand Industrial Technology Development Organization (NEDO), Japan 


\title{
Statistical copoly(biaryl thioether sulfone)s and copoly(biaryl sulfone)s with di- and tetrasulfonated units as proton conducting membranes
}

\author{
Annika Weiber $^{\mathrm{a}}$, Shogo Takamuku ${ }^{\mathrm{g}}$, Patric Jannasch ${ }^{\mathrm{h}}$, \\ a Lund University, Department of Chemistry (annika.weiber@polymat.Ith.se), ${ }^{9}$ Lund University, Department of \\ Chemistry, "hund University, Department of Chemistry,
}

Sulfonated poly(arylene sulfone)s are attracting interest as an alternative to perfluorosulfonic acid membranes due to their high chemical and thermal stability [1]. However statistical sulfonated poly(arylene ether sulfone)s generally show poor proton conductivity at low relative humidity [2]. The proton conductivity can be improved by the use of block copolymers [3]. These materials do, on the other hand, require a more complex synthetic strategy and are thereby more costly and time consuming to produce. The ideal strategy would be if the physical and structural characteristics of the block copolymers could be combined with the facile and readily controlled synthesis of statistical copolymers. In the presented work statistical sulfonated copoly(biaryl sulfone)s bearing rigid, densely sulfonated units were synthesized. The goal was to promote phase separation, and to improve the proton conductivity. The densely sulfonated units were obtained through the use of a new tetrasulfonated dihalide as co-monomer. This monomer was synthesized from 4,4'-bis[(4chlorophenyl)sulfonyl]-1,1'-biphenyl through lithiation chemistry, which enabled positioning of the sulfonic acid groups in ortho position with respect to the sulfone bridges. Statistical poly(biaryl sulfide sulfone)s were first synthesized through polycondensation. To increase the stiffness of the polymer backbone these copolymers were further oxidized to produce the corresponding poly(biaryl sulfone)s. This was done to decrease the water uptake and modify the proton conductivities of the polymer membranes. A majority of the polymers had the ability to form films, showed high proton conductivity and high thermal stability, making them attractive as proton conducting materials.

[1] Iojoiu C. \& Sanchez J-Y., High Performance Polymers, 2009, 21, 673-692.

[2] Kreuer K.D., Journal of Membrane Science, 2001, 185, 29-39.

[3] Nakabayashi K., Matsumoto K, Higashihara T \& Ueda M., Journal of Polymer Science: Part A: Polymer Chemistry, 2008, 46, 7332-7341. 


\title{
Comparative study of the properties and degradation of sulfonated poly(arylene ether sulfone)s with the same polymer backbone but with different positions of the acid groups
}

\author{
Shogo Takamuku ${ }^{\mathrm{a}}$, Patric Jannasch ${ }^{\mathrm{g}}$, \\ aLund University, Department of Chemistry (shogo.takamuku@polymat.Ith.se), ${ }^{9}$ Lund University, Department of \\ Chemistry,
}

Because of the excellent mechanical strength, high thermal/chemical stability and high gas barrier properties, sulfonated aromatic hydrocarbon-based membranes have been recognised as promising proton-exchange membranes to replace the state-of-the-art perfluorosulfonic acid membranes. In this context, sulfonated poly(arylene ether sulfone)s (SPAESs) have been extensively studied because of the excellent membrane forming ability in combination with the availability of commercial monomers/polymers. However, the acid groups are normally placed directly on the phenyl rings in ortho positions to ether bridges. Consequently, the resulting copolymers are subject to desulfonation which are likely to occur during operation at high temperatures and hydrated conditions, resulting in severe loss of the performance. $(1,2)$ In the present work, SPAESs with different positions of the acid groups but with an identical polymer backbone were systematically investigated for the membrane properties/stabilities.(3) We prepared three different series of SPAESs with three levels of the ion exchange capacity (IEC). The first series have the acid groups placed in ortho positions to the ether bridges (oeSPAES), prepared through post-sulfonation to the polymers. The second and third series carried the acid groups in meta (mSSPAES) and ortho (OSSPAES) positions to the sulfone bridges, respectively, and were prepared by polycondensations using 3,3'disulfonated 4,4'-dichlorodiphenyl sulfone (DCDPS) or 2,2'-disulfonated DCDPS, respectively. The oSSPAES copolymers were found to have a high dimensional stability in water up to $100{ }^{\circ} \mathrm{C}$, even at high IECs. We also found that the osSPAES and msSPAES membranes were better at retaining conductivity at reduced relative humidity than the oeSPAES membranes. Thermogravimetric analyses indicated no differences based on the placement of the acid groups. The resistance to desulfonation by radical attack in Fenton's reagent was found to increase in the order oeSPAES < mSSPAES < osSPAES. An accelerated hydrolysis test was also conducted by immersing the membranes in $0.1 \mathrm{M}$ aq. $\mathrm{HCl}$ at $200{ }^{\circ} \mathrm{C}$ in a sealed vessel. The results showed a dramatic loss of the acid groups of the oeSPAES membranes, while the msSPAES and osSPAES membranes showed a good stability with no significant difference in the loss of acidity.

(1) Kopitzke et al., Polym. Degrad.Stab., 2000, 67, 335;

(2) Hou et al., ChemSusChem, 2011, 4, 1526;

(3) Takamuku et al., Polym. Chem., 2012, 3, 1202. 
59 - Poster session

\title{
Influence of Side Groups on the Properties of Aromatic Polymer Electrolyte Membranes for High Temperature- PEMFCs
}

\author{
Christina Morfopoulou $^{\mathrm{a}}$, Aikaterini Andreopoulou ${ }^{\mathrm{g}}$, Ioannis Kalamaras ${ }^{\mathrm{h}}$, Konstantinia Papadimitriou ${ }^{\mathrm{i}}$, \\ Maria Daletou ${ }^{\mathrm{j}}$, Joannis Kallitsis ${ }^{\mathrm{k}}$, \\ aInstitute of Chemical Engineering Sciences, FORTH/ICE-HT, Patras 26504, Greece (christmorf@gmail.com), \\ ${ }^{9}$ Institute of Chemical Engineering Sciences, FORTH/ICE-HT, Patras 26504, Greece, hInstitute of Chemical \\ Engineering Sciences, FORTH/ICE-HT, Patras 26504, Greece, 'Advent Technologies S. A., Patras Science Park, \\ 26504, Patras, Greece, 'Institute of Chemical Engineering Sciences, FORTH/ICE-HT, Patras 26504, Greece, \\ kDepartment of Chemistry, University of Patras, 26500 Patras, Greece,
}

High Temperature PEM Fuel Cells $\left(130^{\circ} \mathrm{C}-200^{\circ} \mathrm{C}\right)$ offer the distinct advantages over traditional Low Temperature PEMs. The performance and lifetime of a proton conducting high temperature electrolyte is characterized by its acid doping ability, proton conductivity and oxidative stability, which are directly related to the specific chemical structure of the polymeric material. Herein we present our approach to the synthesis of copolymers containing basic pyridine main chain groups having high molecular weights, increased solubility, high mechanical integrity and the ability to form complexes with strong acids. Different polymeric structures have been used in order to examine the influence of the detailed chemical structure on the final membrane properties.[1] The versatility of the polymerization conditions allow the creation of numerous polyelectrolytes. Combining polar pyridine with apolar or polar units as side or as main chain groups led to a vast library of polymers whose properties greatly depend on the precise chemical and topological architecture of the backbone and the pendant groups. For example different modes of oxidative stability were obtained depending on the introduced functional groups. Thus, copolymers bearing pyridine moieties and methyl or carboxylic acid substituents showed exceptional oxidative stability under ex situ Fenton test conditions. Moreover, the dependence of the ionic conductivity on doping level and temperature was examined. It was proven that the functional groups' size, structure and interaction with water play a significant role in the overall doping ability and proton conductivity of the polyelectrolyte. A deeper insight on the chemical structure effect on the properties of the electrolyte will allow proper modifications or design of new materials towards the improvement of their properties.

\section{References}

1. M. K. Daletou et.al. Fuel Cells 2010, 35; C. Morfopoulou et.al. J. Polym. Sci. Part A: Polym. Chem. 2011, 49, 4325; I. Kalamaras et.al. Fuel Cells 2011, 921; M. Geormezi et.al. J. Membr. Sci. 2012, 396, 57.

\section{Acknowledgement}

Financial support of this work from the European Commission ( $\mathrm{FCH}-\mathrm{JU})$ through the program "Understanding the Degradation Mechanisms of Membrane-Electrode-Assembly for High Temperature PEMFCs and Optimization of the Individual Components", DEMMEA FCH-JU 245156 (2010-2012), is greatly acknowledged. 
60 - Poster session

\title{
Fabrication and characterization of proton conducting composite materials for electrolytes in intermediate temperature fuel cells and water electrolysers
}

\author{
$\underline{\text { Annemette Hindhede Jensen }}^{\mathrm{a}}$, Katrine Elsøe ${ }^{\mathrm{g}}$, Tatiana Anfimova ${ }^{\mathrm{h}}$, Erik Christensen ${ }^{\mathrm{i}}$, Jens H. von \\ Barner $^{\mathrm{j}}$, Qingfeng $\mathrm{Li}^{\mathrm{k}}$, Niels J. Bjerrum!, \\ a DTU Energy Conversion (ahije@kemi.dtu.dk), ${ }^{9}$ DTU, hDTU, 'DTU, 'DTU, kDTU, 'DTU,
}

\section{Summary}

By combining phosphate materials in a ceramic composite the mechanical properties can be enhanced. This is investigated by using naturally plastic phosphates in a composite with nonplatic phosphates.

The worldwide development of fuel cells and electrolysers has so far almost exclusively addressed either the low temperature window $\left(20-200{ }^{\circ} \mathrm{C}\right)$ or the high temperature window $\left(600-1000{ }^{\circ} \mathrm{C}\right)$. This work concerns the development of key materials and components of a new generation of fuel cells and electrolysers for operation in the intermediate temperature range from 200 to $400{ }^{\circ} \mathrm{C}$. The intermediate temperature interval is of importance for the use of renewable fuels. Furthermore electrode kinetics is significantly enhanced compared to when operating at low temperature. Thus non-noble metal catalysts might be used. One of the key materials in the fuel cell and electrolyser systems is the electrolyte. Proton conducting materials such as cesium hydrogen phosphates, zirconium hydrogen phosphates and tin pyrophosphates have been investigated by others and have shown interesting potential. [1-3] Certain proton conducting materials are plastic in nature e.g. CsH2PO4, whereas others are not e.g. NdPO4. By combining the materials in a ceramic composite with at least one other component, it is possible that suitable mechanical properties can be reached. A simple way to prepare thin composite sheets is to ball mill a mixture of the components followed by pressing in combination with heat treatment. In this work the density of hot pressed sheets are compared with sheets prepared by pressing followed by heat treatment. The sheets are characterized by SEM, XRD and EIS; the results indicate that the highest densities are obtained by hot pressing.

\section{Acknowledgement}

Funding for this work is obtained from the Danish National Research Foundation (the DanishChinese Center for Intermediate Temperature Proton Conducting systems (PROCON)).

\section{References}

[1] T. Norby. Solid State Ionics 125 (1999) 1-11

[2] O. Paschos, J. Kunze, U. Stimming and F. Maglia, J. Phys. Condens. Matter 23 (2011) $234110(26 p p)$

[3] K. Kwon, M. Yano, H. Sun and J. Park, 2005, US Patent Specification Appl. Publ. 2005221143 A1 200051006 
61 - Poster session

\title{
Cross-linked high acid doping level polybenzimidazole membranes with high conductivity and improved mechanical properties
}

\author{
Aurelien Kreisz $^{\mathrm{a}}$, Nicolas Donzel ${ }^{\mathrm{g}}$, Stephanie Roualdes ${ }^{\mathrm{h}}$, Deborah Jones ${ }^{\mathrm{i}}$, Jacques Roziere ${ }^{\mathrm{j}}$, \\ ${ }^{a}$ CNRS-Univ. Montpellier 2 (deborah.jones@univ-montp2.fr), ${ }^{9} \mathrm{CNRS}$-Univ. Montpellier 2, ${ }^{\mathrm{h}} \mathrm{CNRS}$-Univ. Montpellier 2, \\ 'CNRS-Univ. Montpellier 2, ${ }^{\mathrm{j}} \mathrm{CNRS}$-Univ. Montpellier 2,
}

Phosphoric acid doped polybenzimidazole (PBI) membranes are generally prepared by immersing the PBI membrane in concentrated phosphoric acid, with the uptake of phosphoric acid being a function of temperature, phosphoric acid concentration, and time. Alternatively, monomer precursors to PBI are polymerised in a polyphosphoric acid solvent, and phosphoric acid formed within cast membranes from the PPA by hydrolysis. The phosphoric acid content of $\mathrm{H}_{3} \mathrm{PO}_{4}-\mathrm{PBI}$ membranes prepared by the latter method can be significantly higher than that reached by immersion doping, and the conductivity a factor of 10 higher. Polybenzimidazole membranes with high acid doping levels and conductivity can also be prepared by high temperature dissolution of PBI types in phosphoric or polyphosphoric acid. These solutions gel on cooling to give highly conducting but mechanically weak membranes. We have developed a route to stabilise the high acid doping level polybenzimidazole gel membranes formed in polyphosphoric acid by simultaneous cross-linking of the acid-swollen membrane. This method differs from others wherein cross-linking is carried out on an undoped cast PBI membrane, which is then acid-doped in a subsequent step. With increasing degrees of crosslinking the mechanical properties of the high acid content PBI membranes are significantly improved, while the membranes continue to show conductivity exceeding $180 \mathrm{mS} / \mathrm{cm}$ at 160 ${ }^{\circ} \mathrm{C}$ in a dry conductivity cell. Routes to preparation of cross-linked high phosphoric acid content $\mathrm{PBI}$ membranes of various $\mathrm{PBI}$ compositions will be described, along with the properties of the membranes, including phosphoric acid content and mechanical properties, will be described and compared to those of conventional acid-doped PBI membranes and those prepared by the PPA process.

We acknowledge the financial contribution under QuasiDry, contract 256821 of the European 7th Framework Programme. 
62 - Poster session

\title{
Niobium Phosphates as Intermediate Temperature Proton Conductor
}

\author{
Yunjie Huang ${ }^{\mathrm{a}}$, Qingfeng $\mathrm{Li}^{\mathrm{g}}{ }$, Chao Pan ${ }^{\mathrm{h}}$, Jens Oluf Jensen ${ }^{\mathrm{i}}$, Erik Christensen ${ }^{\mathrm{j}}$, Lars Nilausen \\ Cleemann $^{\mathrm{k}}$, Annemette Hindhede Jensen', Tatiana Anfimova ${ }^{\mathrm{m}}$, Niels J. Bjerrum ${ }^{\mathrm{n}}$, \\ ${ }^{a}$ Technical University of Denmark (yunhu@dtu.dk), ${ }^{9}$ Technical University of Denmark, ${ }^{\mathrm{h}}$ Technical University of \\ Denmark, ${ }^{i}$ Technical University of Denmark, ${ }^{\mathrm{j}}$ Technical University of Denmark, ${ }^{\mathrm{K}}$ Technical University of Denmark, \\ Technical University of Denmark, ${ }^{\mathrm{m}}$ Technical University of Denmark, ${ }^{\mathrm{n}}$ Technical University of Denmark,
}

Great efforts are being made to develop new proton conducting materials as electrolyte for fuel cells operational at intermediate temperatures from 200 to $400{ }^{\circ} \mathrm{C}$ which will bridge the gap between the currently available fuel cells.[1-3] In this temperature range, a number of biofuels can be directly oxidized or reformed to hydrogen via an internal reformer. Electrode kinetics will be significantly enhanced so that non-noble metal catalysts might be used. On the other hand, a wide selection of construction materials is possible will benefit the simplified cell and stack construction as well as low costs. Proton conductors with conductivities of above $0.01 \mathrm{~S}$ per $\mathrm{cm}$ especially under low humidified condition are one of the key materials to achieve the intermediate temperature fuel cells. It is known that several oxyacid salts, typically phosphates, exhibit promising proton conductivities in this temperature range.[4-5] In this work, niobium phosphates were synthesized from niobium oxide treated with phosphoric acid. The obtained phosphates contained polycrystalline phases and most likely a small amount of the amorphous phosphorus-containing phase as well. It was found that the existence of proton-containing groups in the phosphates could be preserved after the heat treatment at temperatures above $500{ }^{\circ} \mathrm{C}$ and contribute to the proton conductivity of the 0.01 $\mathrm{S}$ per $\mathrm{cm}$ level under dry air atmosphere. Higher conductivity was easily to be achieved by adding humidity. The prepared conductors showed acceptable conductivity stability in a period of 50 hours. The fuel cell tests indicated further a close proton transfer number to the theoretical number as well as high and stable OCV at measured temperature from 70 to 200 ${ }^{\circ} \mathrm{C}$. The niobium phosphates have great possibility to be used in intermediate temperature fuel cell and electrolysers.

\section{References}

1 S. M. Haile, D. A. Boysen, C. R. I. Chisholm and R. B. Merle, Nature, 2001, 410, 910-913.

2 D. A. Boysen, S. M. Haile, H. J. Liu and R. A. Secco, Chem. Mater., 2003, 15, 727-736.

3 D. A. Boysen, T. Uda, C. R. I. Chisholm and S. M. Haile, Science, 2004, 303, 68-70.

4 Y. B. Shen, M. Nishida, W. Kanematsu and T. Hibino, J. Mater. Chem., 2011, 21, 663-670.

5 O. Paschos, J. Kunze, U. Stimming and F. Maglia, J. Phys: Conden 


\title{
63 - Poster session
}

\section{Anion conducting polymer membranes for hydrogen production through alkaline water electrolysis}

\author{
David Aili ${ }^{\mathrm{a}}$, Qingfeng $\mathrm{Li}^{\mathrm{g}}$, Erik Christensen ${ }^{\mathrm{h}}$, Jens Oluf Jensen ${ }^{\mathrm{i}}$, Niels J. Bjerrum ${ }^{\mathrm{j}}$, \\ ${ }^{a}$ Technical University of Denmark (larda@dtu.dk), ${ }^{9}$ Technical University of Denmark, ${ }^{\mathrm{h}} \mathrm{Technical}$ University of \\ Denmark, 'Technical University of Denmark, 'Technical University of Denmark,
}

\begin{abstract}
Hydrogen production through water electrolysis will play a key role in a future energy scenario based on renewable energy. The alkaline water electrolysis approach is a mature and durable technology using cheap construction and electrocatalyst materials. However, the conventional technology is energy inefficient and lacks flexibility in terms of scale and dynamic operation capability. One way to meet some of the drawbacks of the current technology is to construct a polymer electrolyte based cell with a so called zero gap design. In such a system the hydroxide ion conducting electrolyte material can be based on either a functionalized polymer with fixed charge carriers or a polymeric diaphragm material that has been doped with an aqueous solution of an alkali metal hydroxide. The advantage with the former concept is that the cell can be fed with pure water instead of a corrosive aqueous hydroxide solution as in the latter one. However, regardless of which concept that is chosen a general challenge in this field is to improve the hydroxide ion conductivity and the durability of the polymer based electrolyte materials. Mechanical stability and gas permeability are also factors that need to be carefully considered. The presented project is a recently started work that aims at screening and developing novel hydroxide ion conducting polymer based materials for alkaline water electrolysis. In collaboration with parallel projects and industrial partners, the materials will be evaluated with respect to their fundamental physicochemical characteristics and tested in electrolysis cells with a zero gap design.
\end{abstract}


64 - Poster session

\title{
Antimony Doped Tin Oxides and Their Composites with Tin pyrophosphates as Catalyst Supports for Oxygen Evolution Reaction in Proton Exchange Membrane Water Electrolysis

\author{
Junyuan $\mathrm{Xu}^{\mathrm{a}}$, Qingfeng $\mathrm{Li}^{\mathrm{g}}$, Erik Christensen ${ }^{\mathrm{h}}$, Xindong Wang ${ }^{\mathrm{i}}$,
} aDTU (junxu@kemi.dtu.dk), ${ }^{9}$ DTU, 'DTU, 'USTB,
}

\begin{abstract}
Summary
Iridium oxide supported on the composite materials with improved catalytic activity •Better anodic performance and good stability at $130{ }^{\circ} \mathrm{C}$ in a duration of 760 hours
\end{abstract}

Proton exchange membrane water electrolysers operating at typically $80{ }^{\circ} \mathrm{C}$ or elevated temperature face critical issues of the catalyst activity and durability. In this work, antimony doped tin oxide nanoparticles were synthesized and further doped with an inorganic proton conducting phase based on tin pyrophosphates as the catalyst support. The materials showed an overall conductivity of $0.57 \mathrm{~S} \mathrm{~cm}^{-1}$ at $130{ }^{\circ} \mathrm{C}$ under the water vapor atmosphere with a contribution of the proton conduction. Using this composite support, iridium oxide nanoparticle catalysts were prepared and characterized in sulfuric and phosphoric acid electrolytes, showing much enhanced catalytic activity. Electrolyser tests were conducted at both $80{ }^{\circ} \mathrm{C}$ with Aquivion ${ }^{\mathrm{TM}}$ membrane and at $130{ }^{\circ} \mathrm{C}$ with the phosphoric acid doped Aquivion ${ }^{\mathrm{TM}}$ membranes. Significant improvement in the anodic kinetics was achieved on the composite supported catalysts at $130^{\circ} \mathrm{C}$ though the electrolyser cells showed higher ohmic resistance primarily from the membrane and catalyst layer. A durability test of electrolyser cells was carried out at $130{ }^{\circ} \mathrm{C}$ under a current density of $400 \mathrm{~mA} \mathrm{~cm}{ }^{-2}$ in a period of up to 760 hours, showing rather good stability of the system. 
65 - Poster session

\title{
Conductivity of $\mathrm{NdPO}_{4}-\mathrm{CsH}_{2} \mathrm{PO}_{4}$ composites investigated by electrochemical impedance spectroscopy
}

\author{
Tatiana Anfimova $^{\mathrm{a}}$, Qingfeng Li ${ }^{\mathrm{g}}$, Jens Oluf Jensen ${ }^{\mathrm{h}}$, Niels J. Bjerrum ${ }^{\mathrm{i}}$, \\ ${ }^{\mathrm{a}}$ Technical University of Denmark (tatia@kemi.dtu.dk), ${ }^{\mathrm{a}} \mathrm{Technical}$ University of Denmark, ${ }^{\mathrm{h}} \mathrm{Technical}$ University of \\ Denmark, 'Technical University of Denmark,
}

The introduction of alternative materials enables fuel cells to operate at higher temperatures and this would have a great influence on the successful commercialization of fuel cell technology. Considerable effort has been devoted to developing such proton conductors worldwide. Phosphates have a wide range of potential applications either in the form of powders, coatings or dense sintered parts. They have become of growing interest during the past few years especially in the field of ceramic materials. We have prepared neodymium phosphate with structural formula $\mathrm{NdPO}_{4}{ }^{*} \mathrm{nH}_{2} \mathrm{O}$ where $\mathrm{n} \leq 1$ and mixed with $\mathrm{CsH}_{2} \mathrm{PO}_{4}$. Conductivity of phosphates powders composites based on $\mathrm{NdPO}_{4}-\mathrm{CsH}_{2} \mathrm{PO}_{4}$ system was investigated by using electrochemical impedance technique in temperature range of 120-250 ${ }^{\circ} \mathrm{C}$ and humidity control. 


\section{Pendant-sulfonated poly(arylene ether ketone) (PAEK) membranes cross-linked with a proton conducting reagent for fuel cells}

Dukjoon Kim ${ }^{\mathrm{a}}$, Junghwa Park ${ }^{\mathrm{g}}$,

${ }^{a}$ Sungkyunkwan University (djkim@skku.edu), ${ }^{9}$ Sungkyunkwan University,

Poly(arylene ether ketone) (PAEK) bearing a pendent sulfonic acid group was synthesized to prepare polymer electrolyte membranes for fuel cells. For preparation of this membrane, the precursor possessing the reactive carboxylic acid functional group was first synthesized to control the degree of sulfonation and cross-linking. A variety of essential properties for fuel cell membranes such as proton conductivity, water uptake, methanol permeability, and chemical, thermal, and mechanical stability were investigated. The proton conductivity was comparable to Nafion ${ }^{\circledR} 117$ and it did not significantly decrease by addition of the cross-linker because of the sulfonic acid proton conducting group attached to it. Methanol permeability was very low and it decreases with cross-linking density - it decreased down to a fourth of that of Nafion $^{\circledR}$ at $30 \%$ cross-linking density. Cross-linking reduced water uptake and thus enhanced dimensional stability of the membrane. The resistance to oxidation and hydration was also improved by cross-linking. Among a series of cross-linked membranes, the $20 \%$ cross-linked system exhibited the best cell performance associated with excellent membrane properties. 


\title{
67 - Poster session
}

\section{Inorganic-organic membranes from the short side chain perfluorosulfonic acid ionomer for direct methanol fuel cells}

\author{
Kristina Angeli ${ }^{\mathrm{a}}$, Isobella Nicotera ${ }^{\mathrm{g}}$, Deborah Jones $^{\mathrm{h}}$, Jacques Roziere ${ }^{\mathrm{i}}$, \\ ${ }^{\mathrm{a}} \mathrm{CNRS}$ - Univ. Montpellier \& Univ. Calabria (deborah.jones@univ-montp2.fr), ${ }^{\mathrm{g}}$ University of Calabria, ${ }^{\mathrm{h}} \mathrm{CNRS}$-Univ. \\ Montpellier 2, 'CNRS-Univ. Montpellier 2,
}

The presence of an appropriate inorganic phase in proton exchange membranes limits dimensional change through specific interactions between components, and improves fuel cell performance under high temperature low relative humidity conditions [1]. In recent work, we have observed that composite and hybrid membranes derived from short and long side chain perfluorosulfonic acid ionomers in which zirconium phosphate has been grown in situ, have distinct nano- and micro-structural characteristics. As we have reported previously [2], in membranes based on the Nafion $^{\circledR}$-type long side chain ionomer, the zirconium phosphate particles are nanometric (ca. 2-10 nm) in size. Using an identical methodology with AquivionTM, a different multiscale organisation of inorganic material was observed within hybrid membranes of ZrP: a first domain size in the range 2-10 nm, and a second level of spherulite-like organisation with domains of size 0.1-0.5 $\mu \mathrm{m}$ which are preferentially localised in the crystalline regions of AquivionTM. This poster will compare the properties of long and short side chain derived hybrid membranes incorporating ZrP.

[1] D. J. Jones and J. Rozière, Advances in the development of inorganic/organic membranes for fuel cell applications, Adv. Polym. Sci., Fuel Cells I (2008) 215219 264.

[2] B. Bauer, D. J. Jones, J. Roziere,L. Tchicaya, G. Alberti, L. Massinelli, M. Casciola, A. Peraio et E. Ramunni Hybrid organic-inorganic membranes for a medium temperature fuel cell, J. New Mater. Electrochem. Appl., (2000) 387 - 92.

Funding from $\mathrm{FCH}-\mathrm{JU}$ DURAMET is gratefully acknowledged. 
68 - Poster session

\title{
Ionic liquid functionalized mesoporous silica-Nafion nanocomposite membranes for PEMFC application
}

\author{
$\underline{\text { Joong Hee Lee }}{ }^{\mathrm{a}}$, Ananta Kumar Mishra ${ }^{\mathrm{g}}$, Kuila Tapas ${ }^{\mathrm{h}}$, Nam Hoon Kim ${ }^{\mathrm{i}}$, \\ ${ }^{\mathrm{a}}$ Dept of BIN Fusion Technology, Chonbuk National University (jhl@jbnu.ac.kr), ${ }^{9}$ Chonbuk National University, \\ ${ }^{\mathrm{h}}$ Chonbuk National University, 'Chonbuk National University,
}

\section{Summary}

The high proton conductivity of $375 \mathrm{mS} / \mathrm{cm}$ was achieved with the ionic liquid functionalized silica-Nafion-based nanocomposites at $90{ }^{\circ} \mathrm{C}$ and $100 \% \mathrm{RH}$

Polymer electrolyte membrane fuel cells (PEMFCs) have gained increasing interest in the recent years due to their wider range of power generation capability. PEMFC involves the proton migration from anode to the cathode through the polymer membrane. Hence, it requires the polymer membrane to be highly proton conducting without sacrificing thermomechanical stability. Nafion is the most widely accepted material for PEMFC owing to its high proton conductivity, mechanical stability and cell performance under fully hydrated conditions at low temperature. However, it suffers from poor ionic conductivity under low humidity conditions, leading to inferior ionic conductivity at high temperatures. This is mainly due to its proton conduction mechanism. The perfluro-sulfonic acid backbone in Nafion provides an interconnected ion conduction channel within the membrane under fully hydrated condition. However, under low humidity and high temperature, the ion channels in Nafion get disrupted escorting to inferior conductivity. Hydrophilic nature of inorganic fillers partly assists in the membrane hydration and hence, improving the operating temperature and conductivity at high temperature. However, non conducting nature of inorganic fillers acts as a barrier and disrupts the proton conduction channel. In this work, ionic liquid (IL) functionalized mesoporous silica has been used in order to avoid the barrier effect of inorganic fillers and gradual leaching of IL under continuous usage. The modified silica was used for the preparation of Nafion-silica nanocomposite membrane. The nanocomposites possess higher thermo-mechanical stability and water uptake compared to the virgin Nafion. The nanocomposite containing $3 \mathrm{wt} \%$ of ionic liquid modified silica infers the maximum proton conductivity of $375 \mathrm{mS} / \mathrm{cm}$ at $90 \mathrm{oC}$ and $100 \% \mathrm{RH}$. The ionic liquid modified silica-based nanocomposite containing $1 \mathrm{wt} \%$ ILS shows a conductivity of $54.6 \mathrm{mS} / \mathrm{cm}$ at $90{ }^{\circ} \mathrm{C}$ and $30 \%$ $\mathrm{RH}$. 
69 - Poster session

\section{Ultra-low Pt load PEM anodes}

Gonzalez Daniel $^{\mathrm{a}}$, Fernandez Francisco ${ }^{\mathrm{g}}$, Garcia-Luis Alberto ${ }^{\mathrm{h}}$,

${ }^{\mathrm{a}} \mathrm{Tecnalia}$ (daniel.gonzalez@tecnalia.com), ${ }^{\mathrm{9}} \mathrm{Tecnalia},{ }^{\mathrm{h}} \mathrm{Tecnalia}$

\section{Summary}

In the present work PVD technology it has been evaluated to minimize the Pt catalyst loading in the PEM anode proving that $10 \mathrm{mg} / \mathrm{Kw}$ is a viable target and the feasibility of this technology.

PEM fuel cells are a promising and clean source of electric power that presently uses Pt as catalyst for hydrogen oxidation and oxygen reduction. In the last 30 years the Pt load has decreased from several grams per kilowatt to about $200 \mathrm{mg} / \mathrm{Kw}$. The price of this precious metal is expensive to get a wide commercialization and very dependent of the fluctuation of the markets. Despite the efforts in avoiding its use there are not clear alternatives to $\mathrm{Pt}$ in acidic media so its content must be minimized. One way to get this reduction is by concentrating catalyst close to the membrane in a very thin layer and in this line PVD (Physical Vapor Deposition) can help to control it. In the present work PVD technology has been evaluated to reduce the Pt loading in the anode side. Different loads from 15 to 150 $\mu \mathrm{g} / \mathrm{cm}^{2}$ were applied on commercial GDLs to be compared. The Pt grain size growing was analyzed by SEM and it was checked it is possible to get Pt clusters smaller than $10 \mathrm{~nm}$, depending on the deposition time. The cell performance was tested in a single cell of $14 \mathrm{~cm}^{2}$ active area and the results proved the performance it is not been seriously affected despite having reduced the $\mathrm{Pt}$ load to 1/10th of the present commercial electrodes. The specific $\mathrm{Pt}$ catalyst load in the anode has been reduced to $10 \mathrm{mg} / \mathrm{Kw}$, which confirms PVD as promising technology in order to minimize the catalyst content. 
70 - Poster session

\title{
Synthesis and Electrochemical Testing of Pt-Cr Alloys as Cathode Catalyst for Proton Exchange Membrane Fuel Cells
}

\author{
Gaurav Gupta $^{\text {a }}$, Surbhi Sharma ${ }^{g}$, Paula M. Mendes ${ }^{\text {h }}$, \\ a University of Birmingham, UK (gxg082@bham.ac.uk), ${ }^{9}$ University of Birmingham, UK, "University of Birmingham,
}

\begin{abstract}
Nanoparticles of Pt-Cr (1:1) alloy stabilised with Nafion were synthesized using the sodium borohydride reduction method $[1,2]$. The Nafion stabilisation was performed in order to protect the $\mathrm{Pt}-\mathrm{Cr}$ alloy nanoparticles against dissolution and sintering. These particles were characterised using transmission electron microscopy (TEM) and tested on different supports (Vulcan and Graphene Oxide, GO) for the possible use in Proton Exchange Membrane Fuel Cells (PEMFCs). The results show that the GO supported Pt-Cr nanoparticles (35.6 \pm 3.8 $\mathrm{m} 2 / \mathrm{gpt}$ ) have slightly higher electrochemical active surface area (ECSA) as compared to the Vulcan supported catalyst $\left(28.9 \pm 1.6 \mathrm{~m}^{2} / \mathrm{gpt}\right)$ in $0.1 \mathrm{M} \mathrm{HClO} 4$ solution at $25^{\circ} \mathrm{C}$. This ECSA is very low as compared to the standard $\mathrm{Pt} / \mathrm{C}$ catalyst as reported in literature $\left(\sim 60-80 \mathrm{~m}^{2} / \mathrm{gpt}\right)$ $[3,4]$. However, the specific activity (is, $1.2 \mathrm{~mA} / \mathrm{cm}^{2} \mathrm{Pt}$ ) and mass activity (im, $0.4 \mathrm{~A} / \mathrm{mgpt}$ ) at $0.9 \mathrm{~V}$ for Pt-Cr catalyst in present work shows almost four fold increase in the specific activity $\left(\sim 0.3 \mathrm{~mA} / \mathrm{cm}^{2} \mathrm{Pt}\right)$ and twice the mass activity $(\sim 0.2 \mathrm{~A} / \mathrm{mgPt})[3,4]$. This suggests that the Pt-Cr alloys stabilized with Nafion shows a promising alternative in reducing the dependence on $\mathrm{Pt}$ for catalyst and increased performance of the fuel cell.
\end{abstract}

\section{Reference:}

1. Sabrina C. Zignani, Ermete Antolini, Ernesto R. Gonzalez, Journal of Power Sources 182 (2008) 83-90.

2. E. Antolini, J.R.C.Salgado, L.G.R.A.Santos, G.Garcia, E.A.Ticianelli, E.Pastor, E.R.Gonzalez, Journal of Applied Electrochemistry 36 (2006) 355-362.

3. Ikuma Takahashi, Shyam S. Kocha, Journal of Power Sources 195 (2010) 6312-6322.

4. Yannick Garsany, Olga A. Baturina, Karen E. Swinder-Lyons, Shyam S. Kocha, Analytical Chemistry 82(15) (2010) 6321-6328. 
71 - Poster session

\title{
Platinum-Cobalt Catalysts for the Oxygen Reduction Reaction in HT PEMFCs
}

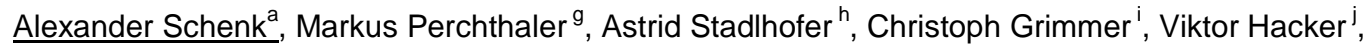 \\ anstitute of Chemical Engineering and Environmental Technology, Graz University of Technology, Austria \\ (alexander.schenk@tugraz.at), ${ }^{9}$ elcomax $\mathrm{GmbH}$, Institute of Chemical Engineering and Environmental Technology, \\ Graz University of Technology, Austria, 'Institute of Chemical Engineering and Environmental Technology, Graz \\ University of Technology, Austria, Institute of Chemical Engineering and Environmental Technology, Graz University \\ of Technology, Austria,
}

Fuel cell technology enables a clean and efficient energy conversion with high energy density. So far, this promising technology has not penetrated the market to compete with conventional power sources. The reasons are mainly found in the high costs of the catalysts, which are made of pure platinum in the current state of the art. By the appropriate combination of Pt with transition metals, it is possible to significantly increase the activity of the catalyst, based on the amount of platinum used, and consequently to reduce costs. Currently, these co-catalysts are not stable in the acidic environment of a polymer electrolyte membrane. The corrosive operating conditions lead to gradual dissolution of the transition metal, whereby the catalysts deactivate after short operating time. Within this work Pt-Co catalysts were prepared by impregnation of previously fabricated gas diffusion electrodes followed by a mild thermal treatment step in the range from $180-240^{\circ} \mathrm{C}$. Cyclic voltammetry of the samples revealed high electrochemical active surface areas. Furthermore, various strategies to increase the stability of the prepared Pt-Co catalysts have been pursued. The main focus was set on the enhancement of the Platinum surface area by surface dissolution of the transition metal and the syntheses of core-shell Pt-Co nanoparticle catalysts. All catalysts, prepared in this study, were investigated by means of cyclic voltammetry, RDE to study the oxygen reduction reaction (ORR) activity and X-ray diffraction. Acknowledgement:

This work is funded by The Austrian Federal Ministry of Transport, Innovation and Technology and The Austrian Research Promotion Agency (FFG) within the program a3plus 
72 - Poster session

\title{
Ordered multimodal porous carbon as an efficient catalyst support in proton exchange membrane fuel cell
}

\author{
Jong-Sung $\mathrm{Yu}^{\mathrm{a}}$, Sun Young Kwon ${ }^{g}$, Hyun-Yeol Park ${ }^{\mathrm{h}}$, Min Young Song ${ }^{\mathrm{i}}$, Dae-Soo Yang ${ }^{\mathrm{j}}$, \\ ${ }^{a}$ Korea University (jsyu212@korea.ac.kr), ${ }^{9}$ Korea University, ${ }^{\mathrm{h}}$ Korea University, 'Korea University, ${ }^{\mathrm{j}}$ Korea University,
}

\begin{abstract}
Summary
Ordered multimodal porous carbon, catalyst support, cathode electode, high Pt Loading, proton exchange membrane fuel cell
\end{abstract}

Proton exchange membrane fuel cell (PEMFC) as a low-temperature fuel cell has attracted much attention as future energy sources. Catalyst support technology has been proved as an important approach to enhance the utilization of the platinum [1]. Carbon black Vulcan XC-72 (VC) has been usually used as a catalyst support for low-temperature fuel cells $[2,3]$. However, VC contains some primary pores with the size being less than $1.0 \mathrm{~nm}$ which are inaccessible to the electrolyte polymer, and the catalyst nanoparticles engulfed in the pores do not contribute to the electrochemical reactions due to lack of the three-phase boundary. In this study, ordered mutimodal porous carbon (OMPC) has been fabricated through inverse replication of silica template [4] and explored to support high loading of Pt and PtRu nanoparticles as electrocatalysts in PEMFC. The superb characteristics such as ordered hierarchical nanostructure consisting of ordered macropores of $300 \mathrm{~nm}$ and interconnected mesopores of $10-20 \mathrm{~nm}$, large surface area and mesopore volume enable the OMPC to support high loading (60 wt\%) of Pt-based nanoparticles with uniform dispersion and small particle size. The OPMC-supported $\mathrm{Pt}(50)-\mathrm{Ru}(50)$ anode catalyst has demonstrated great improvement in electrocatalytic activity toward hydrogen oxidation and much higher power density (an enhancement $~ 50 \%$ ) than the commercial carbon black Vulcan XC-72-supported $\mathrm{Pt}-\mathrm{Ru}$ in PEMFC application. In addition, compared to carbon black Vulcan XC-72 (VC)supported Pt (60 wt\%), the OMPC-supported one has exhibited greatly enhanced catalytic activity toward oxygen reduction reaction and considerably improved PEMFC performance.

\section{References}

[1] B. Fang, J. H. Kim, C. Lee, and J. -S. Yu, J. Phys. Chem. C 112 (2008) 639.

[2] K. Kinoshita, "Electrochemical Oxygen Technology", John Wiley \& Sons, New York, 1992.

[3] S. B. Yoon, B. Fang, M. Kim, J. H. Kim and J. -S. Yu, Nanostructured Materials Vol. I, G. Wilde(Ed), Chapter 4. 2009.

[4] B. Fang, J. H. Kim, M. -S. Kim and J. -S. Yu, Chem. Mater. 21 (2009) 789. 


\title{
73 - Poster session
}

\section{Pt based PEMFC catalysts from colloidal particle suspensions - a toolbox for model studies}

\author{
Jozsef Speder $^{\mathrm{a}}$, Lena Altmann ${ }^{\mathrm{g}}$, Marcus Bäumer ${ }^{\mathrm{h}}$, Matthias Arenz ${ }^{\mathrm{i}}$, \\ a University of Copenhagen (jozsef@chem.ku.dk), ${ }^{9}$ University of Bremen, ${ }^{\text {h} U n i v e r s i t y ~ o f ~ B r e m e n, ~}{ }^{\text {i University of }}$ \\ Copenhagen,
}

Polymer membrane fuel cells (PEMFCs) represent a key technology for clean, efficient and sustainable energy conversion. One of the main problems in PEMFCs, however, is the sluggish oxygen reduction reaction (ORR) as well as the stability of the electrocatalysts under dynamic conditions. Therefore, one of the core parts in PEMFC research is focusing on the understanding and development of high performance cathode electrocatalysts. The objective of our work is to prepare and study model catalysts that can help to understand and thereby improve the existing commercially available electrocatalysts. A typical PEMFC catalyst consists of high surface area carbon supported Pt or Pt-alloy nanoparticles. Previous studies report - sometimes with contradicting conclusions - on the influence of the support, particle size and composition on the ORR activity and the electrochemical stability. In general however, these studies do not selectively change only one of the variables, for example the Pt loading, while leaving the others constant, e.g. the particle size. Furthermore, concerning the degradation mechanism, it is seen that even changes in the synthesis procedure can influence the behaviour [1]. As a consequence, some of the drawbacks related to studying commercially available catalysts are the lack of information provided by the manufacturer regarding their synthesis routes. In our work we introduce a reliable, artefact-free method for studying these effects by synthesising carbon supported, Pt based catalysts from colloidal dispersions of well defined Pt NPs synthesized by a ethylene glycol method [2]. We demonstrate that this preparation method enables a controlled synthesis of model catalysts where individual parameters such as support material and Pt loading can be tuned without changing other parameters. Thus for example the role of support material, Pt loading etc. can be investigated separated from each other.

[1] K. Schlögl, M. Hanzlik, M. Arenz, Comparative IL-TEM study concerning the degradation of carbon supported Pt-based electrocatalysts, Journal of the Electrochemical Society, 159 (2012) B677-B682.

[2] Y. Wang, J. Ren, K. Deng, L. Gui, Y. Tang, Preparation of Tractable Platinum, Rhodium, and Ruthenium Nanoclusters with Small Particle Size in Organic Media, Chemistry of Materials, 12 (2000) 1622-1627. 
74 - Poster session

\title{
Effects of Heat Treatments in the Performance of Bimetallic $\mathrm{Pt}_{3} \mathrm{Mo}_{2} / \mathrm{C}$ Catalysts as CO Tolerant Anodes on Proton- Exchange Membrane Fuel Cells
}

\author{
Ayaz Hassan ${ }^{\mathrm{a}}$, Valdecir Paganin ${ }^{\mathrm{g}}$, Edson Ticianelli ${ }^{\mathrm{h}}$, \\ anstitute of Chemsitry Sao Carlos USP, Sao Carlos, SP Brazil (ahasan333@yahoo.com), ${ }^{9}$ Institute of Chemsitry Sao \\ Carlos USP, Sao Carlos, SP Brazil, "Institute of Chemsitry Sao Carlos USP, Sao Carlos Brazil,
}

\section{Summary}

Heat treated bimetallic PtMo/C electrocatalyst was tested as $\mathrm{CO}$ tolerant anode catalyst in proton exchange membrane fuel cell and was found more $\mathrm{CO}$ tolerant and stable than untreatd PtMo/C.

In this work the performance of heat-treated bimetallic carbon supported PtMo (60:40) catalysts were investigated as $\mathrm{CO}$ tolerant anodes on a proton exchange membrane fuel cell (PEMFC). The catalysts were prepared by the formic acid reduction method and subjected to thermal treatments at several temperatures. The prepared materials were characterized by temperature programmed reduction (TPR) analyses and x-ray diffraction (XRD). The electrochemical behavior was characterized by $\mathrm{H}_{2}-100 \mathrm{ppm} \mathrm{CO} / \mathrm{O}_{2}$ single cell polarization measurements at $85{ }^{\circ} \mathrm{C}$ and cyclic voltammetry performed in membrane electrode assembly (MEA) arrangements. The stabilities of the electrocatalysts were investigated by performing cyclic voltammetry of anodes up to 5000 cycles in installment of 1000 cycles, at a scan rate of $50 \mathrm{mV} \mathrm{s}^{-1}$. Results show that the bimetallic PtMo/C electrocatalysts are somewhat unstable and suffer from gradual loss of Mo due to its dissolution, producing ionic Mo species which ultimately pass from the anode to the cathode side of the single cell. The thermally heated $\mathrm{PtMo} / \mathrm{C}$ electrocatalyst showed an enhanced electrocatalytic activity, greater stability and greater $\mathrm{CO}$ tolerance as compared to untreated $\mathrm{PtMo} / \mathrm{C}$, presenting an overpotential loss of $100 \mathrm{mV}$ at $1 \mathrm{~A} \mathrm{~cm}^{-2}$ due to the presence of $100 \mathrm{ppm} \mathrm{CO}$. 
75 - Poster session

\title{
Alternative supports for PEM Fuel Cell Catalysts
}

\author{
Alessandro Zana $^{\mathrm{a}}$, Marcus Baeumer ${ }^{\mathrm{g}}$, Matthias Arenz ${ }^{\mathrm{h}}$, \\ a University of Copenhagen Chemistry Departement (alessandro@chem.ku.dk), ${ }^{9}$ University Of Bremen, Institute for \\ Applied and Physical Chemistry, 'University of Copenhagen, Chemistry Departement,
}

Carbon corrosion is one of the main issues in the development of degradation resistant high surface area catalysts for PEM (Polymer Electrolyte Membrane) fuel cells. In this work, new corrosion resistant substrates, like $\mathrm{TiO}_{2}$ and $\mathrm{TiOC}$, were tested as possible alternatives to Carbon. The use of a colloidal method to synthesize the catalyst enables us to use the same preparation procedure for the catalysts, independent of the substrate. We obtained a high $\mathrm{Pt}$ dispersion on TiOC supports - comparable to commercials $\mathrm{Pt} / \mathrm{C}$, whereas on $\mathrm{TiO}_{2}$ substrates the electrochemically active surface area (ECSA) proved to be ten times smaller than for the TiOC substrate. This result might be interpreted due to a reduced conductivity of the support. By using TEM in combination with ECSA measurements, the favorable dispersion of Pt on the TiOC support has been demonstrated. Oxygen reduction reaction (ORR) activities have been measured in $0.1 \mathrm{M} \mathrm{HClO}_{4}$ showing a specific activity $\left(\mathrm{A} / \mathrm{m}^{2} \mathrm{Pt}\right)$ and mass activity $(\mathrm{A} / \mathrm{gPt})$ comparable to commercial available $\mathrm{Pt} / \mathrm{C}$. The corrosion resistant behavior of $\mathrm{Pt} / \mathrm{TiOC}$ has been tested in a half-cell setup and compared with standard Pt/EC300 catalyst with equivalent ECSA and the same particle size. 


\title{
Effect of Se modification of $\mathrm{Ru}_{3} \mathrm{Se}_{\mathrm{y}} / \mathrm{C}$ electrocatalysts on the oxygen reduction activities in the presence of phosphoric acid
}

\author{
Jong Hyun Jang ${ }^{a}$, Hee-Young Park ${ }^{b}$, Sung Jong Yoo ${ }^{g}$, Kug-Seung Lee ${ }^{h}$, Yung-Eun Sung ${ }^{i}$, Hyoung- \\ Juhn Kim ${ }^{\mathrm{j}}$, EunAe Cho ${ }^{\mathrm{k}}$, Dirk Henkensmeier', Tae-Hoon Lim ${ }^{\mathrm{m}}$, \\ ${ }^{a}$ Korea Institute of Science and Technology (KIST) (jonghyun.jang@gmail.com), ${ }^{b}$ Korea Institute of Science and \\ Technology (KIST) \& Seoul National University, ${ }^{9}$ Korea Institute of Science and Technology (KIST), "University of \\ Texas at Austin, 'Seoul National University, 'Korea Institute of Science and Technology (KIST), ${ }^{\mathrm{K}} \mathrm{Korea}$ Institute of \\ Science and Technology (KIST), 'Korea Institute of Science and Technology (KIST), ${ }^{m}$ Korea Institute of Science and \\ Technology (KIST),
}

\section{Summary}

The ORR activity of Se modified $\mathrm{Ru}_{3} \mathrm{Se}_{\mathrm{y}} / \mathrm{C}$ was increased with addition of phosphoric acid (PPA), while the half wave potential of $\mathrm{Ru}_{3} \mathrm{Se}_{1} / \mathrm{C}$ was $0.609 \mathrm{~V}$ vs. NHE. In-situ XAS was carried out with PPA.

As the available site for oxygen reduction reaction (ORR) is significantly decreased, strong adsorption of phosphoric acid anion (PAA) on Pt electrode is a crucial problem in the high temperature-polymer electrolyte membrane fuel cells (HT-PEMFCs) with phosphoric acid doped PBI membrane. To solve this problem, there has been two approaches: tuning the electronic structure of Pt electrode by alloying and molecular patterning the Pt surface to selectively prevent PAA adsorption. The Ru nanoparticles modified by Se has been known as a methanol tolerant Pt-free electrocatalyst, where the enhanced ORR activity was explained by the decreased oxygen coverage on Ru by Se modification. In the same analogy, the Ru3Sey nanoparticles were expected to have low PAA adsorption energy as the oxygen adsorption strength and anion adsorption strength had similar trend. In the case of Ru/C, with addition of $10 \mathrm{mM}$ phosphoric acid, the kinetic current density of ORR at $0.6 \mathrm{~V}$ vs. NHE was decreased by $27 \%$, and, in $\mathrm{CV}$, anodic peak due to the PAA adsorption appeared at $\sim 0.5 \mathrm{~V}$. However, with Se modification, the ORR activity of $\mathrm{Ru}_{3} \mathrm{Se}_{y} / \mathrm{C}$ was rather increased with addition of phosphoric acid, while the PAA adsorption peak was not observed in CV in the presence of $10 \mathrm{mM}$ phosphoric acid. The half wave potential of $\mathrm{ORR}$ on $\mathrm{Ru}_{3} \mathrm{Se}_{1} / \mathrm{C}$ was 0.609 $\mathrm{V}$ vs. NHE, which is lower by ca. $0.2 \mathrm{~V}$ compared to the commercial $\mathrm{Pt} / \mathrm{C}$. To investigate the origin of increased ORR activity in the presence of PAA, oxidation state of Ru and Se was examined with in-situ XAS. 


\title{
77 - Poster session
}

\section{Synthesis dependent composition and electrocatalytic properties of $\mathrm{Pt}_{\mathrm{x}} \mathrm{Co}_{1-\mathrm{x}}$ alloys.}

\author{
Ioannis Spanos ${ }^{\mathrm{a}}$, Matthias Arenz ${ }^{\mathrm{g}}$, \\ a'Department of Chemistry, University of Copenhagen (ioaspanos@chem.ku.dk), ${ }^{9}$ Department of Chemistry, \\ University of Copenhagen,
}

Pt based alloys are a matter of considerable interest as catalysts for polymer electrolyte fuel cells (PEMFC) because of their very high activity for the oxygen reduction reaction (ORR). However, one major complication is the base metal dissolution/dealloying which has a detrimental effect on the activity of the PEMFCs. In this work we present a systematic study on different impregnating and colloidal methods for preparing very well distributed and highly active PtxCo1-x alloys supported on a commercial carbon black support (E-Tek/EC300). To promote the alloying effect, we conducted heat treatments on the samples in temperatures varying from $300-500{ }^{\circ} \mathrm{C}$, in $\mathrm{H}_{2}$ atmosphere. In order to compare the ORR activity and the stability/dealloying over time of the different samples, we conducted electrochemical measurements in a RDE setup, in $0,1 \mathrm{M} \mathrm{HClO}_{4}$. The experimentally measured activity of the $\mathrm{Pt}_{\mathrm{x}} \mathrm{Co}_{1-\mathrm{x}}$ alloys and their stability, suggest that the method of preparing the alloys has a great impact on the final alloy composition and their properties. To support our results and to study the effect of the different methods on the alloy particle size and metal composition, Transmission Electron Microscopy (TEM) and Energy Dispersive X-ray Spectroscopy (EDX) were conducted, respectively. 
78 - Poster session

\section{Poly(benzimidazole)-functionalized graphene as a stable and durable support for PEM fuel cell electrocatalysts}

Anastasia A. Permyakova ${ }^{a}$, Jens Oluf Jensen ${ }^{g}$, Qingfeng $\mathrm{Li}^{\mathrm{h}}$, Niels J. Bjerrum ${ }^{\mathrm{i}}$, ${ }^{\mathrm{a}}$ Technical University of Denmark (anper@dtu.dk), ${ }^{\mathrm{g}} \mathrm{Technical}$ University of Denmark, ${ }^{\mathrm{h}} \mathrm{Technical}$ University of Denmark, 'Technical University of Denmark,

\section{Summary}

Fuel cell; Electrocatalyst; Graphene; PBI;

Stable and durable electrocatalysts are a crucial factor for global commercialization of PEM fuels cells. Heterogeneous carbon materials recommend themselves as an electrically conductive support for the state-of-the-art Pt catalyst, but these structures are still afflicted from durability issues coming up from a weak interaction between the platinum and the carbon support. In this work we will present polybenzimidazole (PBI) functionalized graphene as a stable support for Pt-based electrocatalysts (Pt/Graphene-PBI). The honeycomb lattice of graphene act as an ideal platform to anchor Pt with accessible graphene active sites and $\mathrm{PBI}$ act as Pt nanoparticle adsorbent for PBI covered graphene. We will discuss enhanced efficiency of $\mathrm{Pt}$ loading due to the formation of the so called triple-phase boundary nanostructures formed between graphene, aromatic nitrogen incorporated in the PBI structure, and Pt nanoparticles. 
79 - Poster session

\title{
A Pt-free catalyst based on Fe-N-C composites for oxygen reduction reaction (ORR)
}

\author{
Abdouelilah Hachimi ${ }^{a}$, Merzougui Belabbes ${ }^{g}$, Abbas Hakeem $^{\text {h}}$, Akeem Akinpelu ${ }^{i}$, Saheed Bukola ${ }^{j}$, \\ Taher Laoui ${ }^{k}$, Muataz Ali Atieh Hussien', \\ a'Center of Nanotechnology (CENT), KFUPM, Dhahran 31261 Saudi Arabia (ahachimi@kfupm.edu.sa), ${ }^{9}$ Center of \\ Nanotechnology (CENT) \& Department of Chemistry, KFUPM, Dhahran 31261 Saudi Arabia, ${ }^{\mathrm{h}}$ Center of \\ Nanotechnology (CENT), KFUPM, Dhahran 31261 Saudi Arabia, 'Center of Nanotechnology (CENT), KFUPM, \\ Dhahran 31261 Saudi Arabia, ${ }^{j}$ Center of Nanotechnology (CENT), KFUPM, Dhahran 31261 Saudi Arabia, \\ ${ }^{k}$ Department of Mechanical Eng., Dhahran 31261 Saudi Arabia, 'Department of Chemical Eng. Dhahran 31261 Saudi \\ Arabia,
}

\section{Summary}

A composite based on Fe-N-CNTs was synthesised and characterized as a Pt-free catalyst for ORR for fuel cells. This catalyst demonstrated good activity and durability in acidic medium.

Cost and durability of PEM fuel cells have delayed significantly their commercialization. The main challenge is to reduce the cost associated with cathode catalyst for oxygen reduction reaction (ORR) [1]. Recently, a great attention has been shifted towards nitrogen-modified carbon materials because of their excellent properties, such as electrical conductivity and catalytic activity for various applications [1-5]. In particular, the ability of coordination of iron to nitrogen containing carbon nanotubes (CNTs) has made these materials more catalytically active for ORR in fuel cells $[1,2,5]$. In this context, we have developed Iron-nitrogen-modified CNTs materials through polymerization of aniline on the surface of CNTs, followed by complexation of iron sources, such as $\mathrm{FeCl}_{3}$ using wet chemistry method. As a final step, the mixture was subjected to heat treatment in nitrogen or ammonia atmospheres at $900^{\circ} \mathrm{C}$ for one hour. The obtained catalysts, noted as Fe-N-CNTs, were characterized by XRD, SEMEDXs, RAMAN spectroscopy and electrochemical technique. XRD patterns showed the formation of a composite based on iron-carbide-nitride on carbon surface (FexNyCz/C). RAMAN spectroscopy revealed two broad bands at $1585\left(\mathrm{~cm}^{-1}\right)$ and $1350\left(\mathrm{~cm}^{-1}\right)$ corresponding to G-band and D-band respectively. The broadness of D-band peak for $\mathrm{Fe}_{\mathrm{x}} \mathrm{N}_{\mathrm{y}} \mathrm{C}_{\mathrm{z}} / \mathrm{C}$ samples could indicate the defect introduced in the structure of graphitic carbon as result of nitrogen modification. The catalyst $\mathrm{Fe}_{\mathrm{x}} \mathrm{N}_{\mathrm{y}} \mathrm{C}_{z} / \mathrm{C}$ was evaluated for ORR and showed a good activity with onset potential of $940 \mathrm{mV} / \mathrm{RHE}$. Also, the system $\mathrm{Fe}_{x} \mathrm{~N}_{\mathrm{y}} \mathrm{C}_{\mathrm{z}} / \mathrm{C}$ demonstrated good stability at $940 \mathrm{mV} / \mathrm{RHE}$ for $140 \mathrm{~h}$ in oxygen atmosphere. Such a composite could be an excellent candidate as Pt-free catalyst for PEMFCs as well as direct methanol fuel cells (DMFCs).

\section{Reference:}

[1] Y. Li, W. Zhou, H. Wang, L. Xie, Y. Liang, F. Wei, J-C. Idrobo, S-J. Pennycook, H. Dai, Nature Nanotechnology 7 (2012) 394-400

[2] Z. Wang, R. Jia, J. Zheng, J. Zhao, L. Li, J. Song and Z. Zhu, Journal of American Chemical Society Nano, 5 (2011) 1677-1684

[3] E. Proidetti, F. Jaouen, M. Lefevre, N. Larouche, J. Tian, J. Herranz, J-P. Dodelet, Nature Communication 2, 416 (2011) 1-9

[4] C-W. Tsai, H-M. Chen, R-S, Liu, K. Asakura, L. Zhang, J. Zhang, M-Y. Lo, Y-M, Peng, Electrochemica Acta 56 (2011) 8734-8738

[5] P. Ayala, R, Arenal, M, Rummeli, A. Rubio, T. Pichler, carbon 48 (2010) 575-586. 
80 - Poster session

\title{
Tungsten carbide promoted Pd and Pd-Co electrocatalysts for formic acid electrooxidation
}

\author{
Min Yin ${ }^{\mathrm{a}}$, Qingfeng $\mathrm{Li}^{\mathrm{g}}$, Jens Oluf Jensen ${ }^{\mathrm{h}}$, Yunjie Huang ${ }^{\mathrm{i}}$, Lars Nilausen Cleemann ${ }^{\mathrm{j}}$, Niels J. Bjerrum $^{\mathrm{k}}$, \\ Wei Xing ', \\ ${ }^{a}$ Changchun Institute of Applied Chemistry, Technical University of Denmark (yinmin@ciac.jl.cn), ${ }^{9}$ Technical \\ University of Denmark, ${ }^{\mathrm{h}}$ Technical University of Denmark, 'Technical University of Denmark, 'Technical University of \\ Denmark, 'Technical University of Denmark, 'Changchun Institute of Applied Chemistry,
}

Direct electrooxidation of formic acid is of increasing interest as a potential liquid fuel for fuel cells [1]. Carbon supported palladium is the typical catalyst and however suffers from inefficient activity and poor stability [2]. Introduction of novel support materials with cocatalytic functionality for metal nanoparticles has proven to be an effective approach to improve both catalytic activity and stability of electrocatalysts. Tungsten-based materials have recently been studied as novel supports due to their chemical and electrochemical activities and stabilities for various reactions [3]. The present work is devoted to introducing the functionalized carbon with tungsten carbide (WC) as supports of $\mathrm{Pd}$ and $\mathrm{PdCo}$ nanoparticles for formic acid electrooxidation (FAEO). Promotion effect of the support functionality and palladium alloying were found with best performance achieved on PdCo/WC-C catalysts, as compared with that on $\mathrm{Pd} / \mathrm{C}$ catalyst. The synergistic effect of the carbide support and PdCo alloy nanoparticles was investigated for the observed enhanced catalytic performance. The electronic effect of WC on Pd-based catalyst, on the one hand, could benefit the adsorption of formic acid and the intermediate and intrinsically enhances the catalytic rate of overall FAEO. Additionally, the formation of the hydrogen tungsten bronze of WC in an electrochemical environment could also promote the dissociation of $\mathrm{H}_{2} \mathrm{O}$ into $\mathrm{H}^{+}$and $\mathrm{OH}^{-}$, provide more OHad species to the catalytic sites and accelerate the intermediates oxidation and removal, as known as bifunctional effect.

\section{References}

[1] S. Ha, R.I. Masel, Power Sources 144 (2005) 28.

[2] X. W. Yu, P.G. Pickup, Electrochem. Commun. 11 (2009) 2012.

[3] J. B. Christian, S. P. E. Smith, M. S.Whittingham, H. D. bruna, Electrochem. Commun. 9 (2007) 2128. 
81 - Poster session

\title{
Efficient electrocatalytic oxygen reduction over self- supported polyaniline-based non-precious metal catalyst
}

\author{
$\underline{\text { Yang } \mathrm{Hu}^{\mathrm{a}}}$, Xiao Zhao ${ }^{\mathrm{g}}$, Qingfeng $\mathrm{Li}^{\mathrm{h}}$, Yunjie Huang ${ }^{\mathrm{i}}$, Niels J. Bjerrum ${ }^{\mathrm{j}}$, Changpeng Liu ${ }^{\mathrm{k}}$, Wei Xing , \\ ${ }^{a}$ Changchun Institute of Applied Chemistry, Chinese Academy of Sciences;Technical University of Denmark \\ (yanhu@win.dtu.dk), ${ }^{9}$ Changchun Institute of Applied Chemistry, Chinese Academy of Sciences, ${ }^{\text {h}}$ Technical \\ University of Denmark, 'Technical University of Denmark, ${ }^{\mathrm{j}} \mathrm{Technical}$ University of Denmark, ${ }^{\mathrm{k}} \mathrm{Changchun}$ Institute of \\ Applied Chemistry, Chinese Academy of Sciences, 'Changchun Institute of Applied Chemistry, Chinese Academy of \\ Sciences,
}

Insufficiently active catalysts for the oxygen reduction reaction (ORR) have long been regarded as the major impediment to the commercialization of polymer exchange membrane fuel cells (PEMFCs)[1, 2]. The state-of-the-art cathode catalysts for PEMFCs are based on platinum and its alloy nanoparticles, which are suffering from the prohibitive cost and limited resources. Therefore, developing novel non precious metal catalysts (NPMCs) with high ORR activity and durability is crucial and interesting for the development of PEMFCs[ 3-5]. In this work, a new approach to prepare self-supported non-precious metal catalysts (NPMCs) for oxygen reduction reaction (ORR) was proposed. With this approach, nanoworm-shaped NPMCs for ORR were synthesized with polyaniline nanofibers as both nitrogen as well as carbon precursors. The high onset potential (0.905V vs. RHE) and the near four-electron transfer mechanism for ORR of prepared catalysts testified the reliability of this approach in formation of active sites with high intrinsic activity. The effects of Fe content in the synthesis of this kind of catalyst on ORR activity were also explored. It was found that when the Fe content in the precursors was increased from 0 to $3.0 \mathrm{wt} . \%$, not only the intrinsic ORR activity but also the electron transfer number was increasing, which indicated the nature of active sites had been changed in this process. While with further increase of Fe content in the precursors, different Fe-containing byproduct would form in the synthesis, which would decrease the ORR activity of the final catalyst. 
82 - Poster session

\title{
Transition metal carbides as electrode materials for HT PEM systems
}

\author{
Antonio Luis Tomas Garcia ${ }^{\mathrm{a}}$, Qingfeng $\mathrm{Li}^{\mathrm{b}}$, Niels J. Bjerrum ${ }^{\mathrm{c}}$, \\ aDTU Energikonvertering (tgarc@kemi.dtu.dk), ${ }^{\mathrm{a} D T U}$ Energikonvertering, ${ }^{\mathrm{c}} \mathrm{DTU}$ Energikonvertering,
}

\begin{abstract}
A main challenge in the HT-PEM fuel cells and electrolysers is the durability of the electrode materials, as well as the scarcity and cost of using Pt and other noble metals as catalysts. Thus, there is an ongoing search for lowering the noble metal content of the electrodes. Recent research has shown the possibility of alternatives to the classic Pt/C electrodes for PEM fuel cells and electrolysers. Tungsten carbide has been investigated as catalyst support for Pt in low-temperature PEM systems. WC itself also shows significant activity for HOR and $\mathrm{HER}$ in phosphoric acid. In this work, the behavior of WC and other related compounds in hot $\mathrm{H}_{3} \mathrm{PO}_{4}$ was studied. First, the synthesis WC, TaC, $\mathrm{Mo}_{2} \mathrm{C}, \mathrm{NbC}$ and $\mathrm{Cr}_{3} \mathrm{C}_{2}$ from their metal oxides was explored. In all cases, the synthesis was possible by using methane gas as a carbon source, rather than the metal-carbon mixtures used in industrial production. Afterwards, the electrochemical behavior of these materials was studied in hot phosphoric acid, especially the stability under hydrogen atmosphere.
\end{abstract}


83 - Poster session

\title{
$\mathrm{Pt}_{5} \mathrm{Gd}$ as a highly active and stable catalyst for oxygen electroreduction
}

\author{
Maria Escudero Escribano ${ }^{\mathrm{a}}$, Arnau Verdaguer-Casadevall ${ }^{\mathrm{g}}$, Paolo Malacrida ${ }^{\mathrm{h}}$, Ulrik Grønbjerg ${ }^{\mathrm{i}}$, Brian \\ Knudsen $^{\mathrm{j}}$, Anders Jepsen ${ }^{\mathrm{k}}$, Jan Rossmeisl', Ifan Stephens ${ }^{\mathrm{m}}$, Ib Chorkendorff ${ }^{\mathrm{n}}$, \\ ${ }^{\mathrm{a}}$ Technical University of Denmark (maria.escudero@fysik.dtu.dk), ${ }^{9} \mathrm{Technical}$ University of Denmark, ${ }^{\mathrm{h}} \mathrm{Technical}$ \\ University of Denmark, 'Technical University of Denmark, 'Technical University of Denmark, ${ }^{\mathrm{K}}$ Technical University of \\ Denmark, 'Technical University of Denmark, " $T$ Technical University of Denmark, ${ }^{\mathrm{n}} \mathrm{Technical}$ University of Denmark,
}

\section{Summary}

The activity and stability of $\mathrm{Pt}_{5} \mathrm{Gd}$ for the ORR have been studied, by combining electrochemical measurements, AR-XPS and DFT. $\mathrm{Pt}_{5} \mathrm{Gd}$ shows a five-fold increase in ORR activity, relative to $\mathrm{Pt}$ at $0.9 \mathrm{~V}$.

Proton exchange membrane fuel cells (PEMFCs) are a potentially zero emission source of power, which are expected to play a key role in a future society based on sustainable energy. The main obstacle to the development of PEMFCs as a commercially competitive reality is the high overpotential required for the oxygen reduction reaction (ORR) to proceed at an adequate rate. In order to improve the kinetics for the ORR and reduce the Pt loading, we need to develop more active catalysts, which can be achieved by alloying Pt with other metals [1-3]. Alloys of $\mathrm{Pt}$ and early transition metals, such as $\mathrm{Pt}_{3} \mathrm{Y}$ [2,3], have shown very promising activity for oxygen reduction. Furthermore, alloys of Pt with early transition metals or rare earths are exceptionally stable [3]; this should provide them with the kinetic stability to prevent dealloying under fuel cell reaction conditions, unlike alloys of $\mathrm{Pt}$ and late transition metals. Herein, we report a new catalyst for oxygen reduction, $\mathrm{Pt}_{5} \mathrm{Gd}$. Rotating disk measurements show that sputter-cleaned, polycrystalline $\mathrm{Pt}_{5} \mathrm{Gd}$ shows a five-fold increase in ORR activity, relative to $\mathrm{Pt}$ at $0.9 \mathrm{~V}$ in $0.1 \mathrm{M} \mathrm{HClO}_{4}$, approaching the activity of $\mathrm{Pt}_{3} \mathrm{Y}$ (the most active catalyst in the literature, prepared in this way). We use angle-resolved X-ray photoelectron spectroscopy and density functional theory to elucidate the origin of this high activity. Not only is the catalyst highly active, but also very stable, losing only $14 \%$ of its initial activity after 10,000 cycles between $0.6 \mathrm{~V}$ and $1.0 \mathrm{~V}$ vs. RHE. These results make Pt5Gd very promising for the development of new highly active and long term stable cathode catalysts for fuel cells.

[1] V. R. Stamenkovic, et al. Science 2007, 315, 493.

[2] J. Greeley, et al. Nature Chem. 2009, 1, 552.

[3] I. E.L. Stephens, et al. Energy Environ. Sci. 2012, 5, 6674. 
84 - Poster session

\title{
Determining HTPEM electrode parameters using a mechanistic impedance model
}

\author{
Jakob Rabjerg Vang ${ }^{a}$, Mohamed Mamlouk ${ }^{b}$, Keith Scott ${ }^{g}$, Søren Knudsen Kær ${ }^{\text {h }}$, \\ ${ }^{a}$ Aalborg University (jrv@et.aau.dk), ${ }^{b}$ Newcastle University, ${ }^{g}$ Newcastle University, ${ }^{\text {h}}$ Aalborg University,
}

This work presents a 2D, finite volume based, transient high temperature PEM (HTPEM) fuel cell model which can be used to determine important electrode parameters. The parameters are determined by fitting the model to a data set consisting of a polarisation curve and an impedance spectrum from a single HTPEM fuel cell. By fitting to both curves simultaneously the number of degrees of freedom is lowered, reducing the ambiguity of the fit. The data, to which the model is fitted, was collected in the laboratories at the School of Chemical Engineering and Advanced Materials at Newcastle University. The single cell experimental setup consisted of an electrically heated titanium cell body with gold plated parallel flow channel. The fuel cell active area was $9 \mathrm{~cm}^{2}$. Polarisation curves were recorded by sweeping the voltage from $\mathrm{OCV}$ to $\mathrm{OV}$ at a scan rate of $5 \mathrm{mV} / \mathrm{s}$. Impedance spectra were recorded using two electronic loads. One load was used to polarise the electrode while the other was used for applying a sinusoidal voltage signal of $10 \mathrm{mV}$ amplitude. The frequency range was $30 \mathrm{kHz}$ to $10 \mathrm{mHz}$. The impedance was measured for the cathode only using a dynamic hydrogen electrode as reference. The HTPEM fuel cell model was developed in Matlab using the finite volume method. The fuel cell is resolved in 2D along the channel and across the membrane. The model takes into account anode and cathode activation, double layer capacitance, cathode mass transport by diffusion and convection, diffusion of oxygen and hydrogen in the catalyst layer electrolyte phase, and ionic conduction losses in the membrane and catalyst layers. The model was fitted to data from different MEAs at different operating points. The quality of the fit obtained is considered satisfactory considering the experimental uncertainty. The ability of the model to reliably extract unknown electrode parameters is assessed by comparing the fitted parameters to available data for the MEAs in question as well as to standard values found in the literature. All fitted values fall within the expected range. 


\title{
85 - Poster session
}

\section{Titanium PBI composite membranes for high temperature PEMFC. From a $5 \mathrm{~cm}^{2}$ single cell to a $150 \mathrm{~cm}^{2}$ short stack}

\author{
Justo Lobato ${ }^{a}$, Pablo Cañizares ${ }^{g}$, Manuel Rodrigo ${ }^{h}$, Diego Ubeda ${ }^{i}$, F. Javier Pinar ${ }^{j}, \underline{\text { Hector R. García }^{a}}$

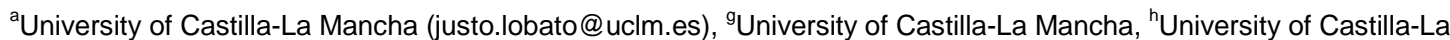 \\ Mancha, 'University of Castilla-La Mancha, 'University of Castilla-La Mancha,
}

\section{Summary}

This work is related with titanium composite PBI based membranes for HT-PEMFCs. Characterisation of the membranes, and performance in both a single cell and a short stack have been evaluated.

One of the main problems in the way of making cheaper and more efficient PEMFCs is the inability of Nafion-like membranes to work above $80-90^{\circ} \mathrm{C}$. As it has been reported elsewhere [1] working at high temperatures has many advantages. Therefore, it is important to use other type of membranes suitable at this elevated temperature. At present, the most interesting candidates for HT-PEMFCs membranes are indeed polybenzimidazole (PBI) and its derivatives (phosphoric acid doped PBI membranes)[1]. The PBI based membranes has a relative lower proton conductivity, acid leaching tendency, and inadequate mechanical stability under fuel cell conditions that restrict their life and use in PEMFCs. Further doping of phosphoric acid increases the conductivity but at the expense of mechanical stability. Hence, enhancement of proton conductivity and mechanical strength along with increased resistance toward acid leaching is a challenge to be overcome successfully, and a tailor-made composite with desired properties should alleviate many of these issues. Recently, novel titanium-based $\mathrm{PBI}$ composite membranes have been characterised and tested in a single fuel cell of $5 \mathrm{~cm}^{2}$ [2]. Because of the good results achieved by these membranes, it was decided to scale up the fuel cell to a short stack of 3 MEAs of $50 \mathrm{~cm}^{2}$ each one. It was evaluated the performance at different operation conditions. A Target to enable the fuel cell commercialization is increase the life service. Thus, long term essays were carried out. During this study the leached phosphoric acid was measured and different stops were carried out, considering the length of all shut-down stages the study lasted more than 1,700 $\mathrm{h}$. The titanium composite PBI based membranes showed a good stability and are good candidates as electrolytes for high temperature PEMFC systems.

\section{Acknowledgement}

The authors thank the JCCM (Junta de Comunidades de Castilla-La Mancha) for the financial support through the Project POII10-0329-5194 and to MCINN (Ministerio de Ciencia e Innovación, Spain) for the fellowship AP2007-02713 awarded to D. Úbeda and the financial support through the project CTM2010-18833/TECNO.

\section{References}

[1] Q. Li, R. He, J.O. Jensen, R.F. Savinel, N.J. Bjerrum, Prog. Polym. Sci., 34, 2009, 449477.

[2] J. Lobato, P. Cañizares, M.A. Rodrigo, D. Úbeda, F.J. Pinar, J. Membr. Sci.,369 , 2011, 105-111. 


\title{
Polymer Selection and Catalyst Ink Preparation for a Membrane Electrode Assembly in a Thermally Regenerative Fuel Cell

\author{
Mark Skerritt ${ }^{\mathrm{a}}$, Philip Jessop ${ }^{\mathrm{g}}$, Brant Peppley ${ }^{\mathrm{h}}$, \\ a'Queen's University (mark.skerritt@gmail.com), ${ }^{9}$ Queen's University, ${ }^{\text {hQ }}$ ueen's University,
}

\begin{abstract}
Methods for developing a Membrane Electrode Assembly (MEA) for a waste heat powered Thermally Regenerative Fuel Cell (TRFC) will be discussed. The TRFC system contains a ketone/alcohol pair, where the waste heat powers the dehydrogenation of the alcohol to the ketone and the fuel cell performs the hydrogenation of the ketone back to the alcohol. Different polymers were screened for compatibility in the system, and a candidate was selected (m-polybenzimidazole). Ink formulations were also optimized for smooth and even flow with the working catalysts for the system that were developed in our group. The ink was applied via an airbrush technique to create the electrode, and the MEA produced via hot press. The MEA was placed inside a $\mathrm{H}_{2} /$ Air based fuel cell, where voltage and current were stabilized by varying the pressure and temperature of the hot press. Different ink formulations were also tested to see which provided the best performance. The $\mathrm{H}_{2} /$ Air fuel cell will show the basic workability of the MEA, before placing the MEA inside our TRFC for comparison. Attempts were then made to optimize the fuel cell assembly and MEA for the TRFC, in terms of power and reliability.
\end{abstract}


87 - Poster session

\title{
Development of MEAs based on electrophoretic deposition for high temperature PEMFC applications
}

\author{
Cecil Felix ${ }^{\mathrm{a}}$, Sivakumar Pasupathi ${ }^{\mathrm{g}}$, Bruno Pollet ${ }^{\mathrm{h}}$, Vladimir Linkov', \\ ${ }^{a}$ South African Institute for Advanced Materials Chemistry (SAIAMC) (cecilfelix09@gmail.com), ${ }^{9}$ South African \\ Institute for Advanced Materials Chemistry (SAIAMC), ${ }^{\text {h}}$ South African Institute for Advanced Materials Chemistry \\ (SAIAMC), 'South African Institute for Advanced Materials Chemistry (SAIAMC),
}

Electrophoretic deposition (EPD) is a process where charged particles are moved to and deposited onto a target substrate by an applied electric field. Compared to other coating processes, EPD has many advantages such as the high uniformity and easy control of the deposited layer. In polymer electrolyte membrane fuel cells (PEMFC), the electrode reaction(s) are usually catalyzed by expensive platinum group metal catalysts. Active research is being carried out on alternative, less expensive catalytic materials as well as attempts to improve the efficiency of utilization of the noble metal catalysts. The EPD process has already been used for the deposition of catalytic layers in membrane electrode assemblies (MEA) for low temperature PEMFC applications [1, 2]. In this study we applied the EPD process to fabricate MEAs for high temperature PEMFC applications. Catalyst suspensions were studied by zetasizer equipment. Zetapotential and particle size were optimized as a function of suspension $\mathrm{pH}$, catalyst particle volume fraction, and suspension ionic strength to produce very stable catalyst suspensions. EPD process parameters i.e. deposition time and applied electric field strength were optimized for fabricating the MEAs. MEA performances were evaluated in a high temperature fuel cell test station. Deposited catalyst layer morphologies were characterized by scanning electron microscope (SEM).

\section{References}

[1] H. Morikawa, T. Mitsui, J.-I. Hamagami, K. Kanamura, Electrochemistry (Tokyo) (2002), 70, $937-939$.

[2] R.F. Louh, H. Huang, F. Tsai, Journal of Fuel Cell Science \& Technology (2007) 4, 72 78. 
88 - Poster session

\title{
Pt-loading into a PEM Surface in a Drying Process
}

\author{
Jae-Young Lee ${ }^{a}$, Hong-Ki Lee ${ }^{b}$, Seung-Weon Yang ${ }^{g}$, Hee-Suck Jung ${ }^{\text {h }}$, \\ ${ }^{\mathrm{a} H y d r o g e n ~ F u e l ~ C e l l ~ C e n t e r, ~ W o o s u k ~ U n i v e r s i t y ~(j j k l e e @ n a v e r . c o m), ~}{ }^{\mathrm{b}}$ Woosuk University, ${ }^{9}$ Woosuk University, \\ "Woosuk University,
}

A gas diffusion layer (GDL) in a fuel cell consists of a thin layer of carbon black powder mixed with an organic binder, hydrophobic dispersion agent and solvents, which is coated onto a sheet of macroporous carbon backing cloth or paper, giving a micro-porous layer onto the macroporous layer of the carbon backing. Then platinum (Pt) nano catalysts were deposited on a membrane assembled side of the GDL because the Pt nano-particles are acted as the most effective catalysts for the hydrogen oxidation on an anode and the oxygen reduction on a cathode in a proton-exchange membrane fuel cell (PEMFC). But it has several critical issues to be modified before the commercialization. For example, the oxygen reduction reaction (ORR) is kinetically limited at the cathode, and the scale of the Pt crystallites leads to high costs for Pt-based electrocatalysts with sufficient surface area and activity. In order to overcome these barriers, many researchers have studied to maximize the activity of a Pt nano catalyst. In this study, we loaded Pt nano particles into a PEM surface via the reduction of platinum(II) bis(acetylacetonato), $\mathrm{Pt}(\mathrm{acac}) 2$ in a drying process. $\mathrm{Pt}(\mathrm{acac})_{2}$ was purchased from Johnson Matthey Materials Technology and it was recryatallized in an acetone solution. $0.05 \mathrm{mg}$ of $\mathrm{Pt}(\mathrm{acac})_{2}$ was sublimed and adsorbed on the PEM surface in a glass reactor. And then it was penetrated into the PEM surface and reduced to Pt nano particles just beneath the PEM surface at $180 \circ \mathrm{o}$ in vacuo for 5 30 min. The loaded Pt nano particles were observed by transmission electron microscopy (TEM) and X-ray photoelectron spectroscopy (XPS). And the effect of Pt loading on the glass transition temperature of PEM was studied by differential scanning calorimetry (DSC) analysis. 
89 - Poster session

\title{
Analysis of kinetic and diffusion losses in large area HT PEMFCs
}

\author{
George Bandlamudi ${ }^{\mathrm{a}}$, Weibo Zhang ${ }^{\mathrm{g}}$, Christian Heßke ${ }^{\mathrm{h}}$, Peter Beckhaus ${ }^{\mathrm{i}}$, Angelika Heinzel ${ }^{\mathrm{j}}$,

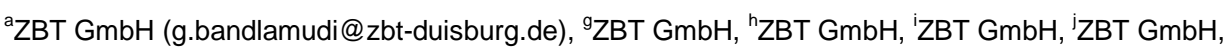

overvoltages caused due to kinetic as well as diffusion limitations associated with high temperature PEMFCs operated in the $130^{\circ} \mathrm{C}-200^{\circ} \mathrm{C}$ is vital to achieving higher fuel cell efficiencies. A HT PEMFC with an active area of $300 \mathrm{~cm}^{2}$ was designed and operated with pure hydrogen as well as with $\mathrm{CO}$ containing hydrogen gas fed into its anode. The flow field structure was optimized to handle CO containing reformate gas, as opposed to pure hydrogen. The flow distribution, pressure drop, and velocity vectors were studied by performing CFD (computational fluid dynamic) simulations performed with Fluent ${ }^{\circledR}$ software. Investigations were performed, employing a single cell $\mathrm{HT}$ PEMFC from $140^{\circ} \mathrm{C}$ to $180^{\circ} \mathrm{C}$ and up to load currents of $500 \mathrm{~mA} / \mathrm{cm}^{2}$ (150 amps), while feeding hydrogen consisting of $1 \%$ and $2 \% \mathrm{CO}$. The kinetic as well as diffusion losses of the HT PEMFC were studied by obtaining impedance spectra at different temperatures and load currents and anode gas stoichiometries, while maintaining air feed stoichiometry at 2.0. Zahner Messtechnik's IM6 was used to perform EIS tests. Influence of inlet gas pressure and cell temperature on the HT PEMFC's diffusion overvoltage and kinetic overvoltage was studied. It is common knowledge that a CO content of $1 \%$ in the anode stream of a HTPEMFC is far from being critical to its performance. However, in the case of large area HT PEMFCs, where non-homogeneities in fluid flow are usual, even with best efforts in optimizing fluid flow employing various techniques, $\mathrm{CO}$ content in the anode stream has its own pronounced influence. Also, the concomitant limitations of oxidant and reactant diffusion in large area cells dictate cell's overall performance. An optimum cell operating window, where overvoltages are kept at their minimum has been identified. The current work analyses various overvoltages and critical factors that influence these overvoltages, which are specific to large area HT PEMFCs. 
90 - Poster session

\title{
Direct dimethyl ether high temperature polymer electrolyte membrane fuel cells with improved performance
}

\author{
Anton Vassiliev $^{\mathrm{a}}$, Jens Oluf Jensen ${ }^{\mathrm{a}}$, Qingfeng $\mathrm{Li}^{\mathrm{a}}$, Niels J. Bjerrum ${ }^{\mathrm{a}}$ \\ ${ }^{a}$ DTU Energy Conversion (anvas@kemi.dtu.dk),
}

The lack of $\mathrm{C}-\mathrm{C}$ bond and the resemblance to methanol makes DME a possible candidate for direct conversion in a fuel cell. A limited number of attempts reported in literature with direct DME PEMFC at temperatures below $100^{\circ} \mathrm{C}$ showed poor performance. The problems are the same as those for DMFC - slow kinetics and large degree of fuel crossover. Besides, DME is a gas at ambient conditions with low solubility in water. When DME and water mixture is supplied to the fuel cell separation in two phases might occur, which inhibits the cell performance further. Using phosphoric acid doped polybenzimidazole (PBI) based membranes it is possible to operate at temperatures above $100{ }^{\circ} \mathrm{C}$, avoiding phase separation problem. Increased temperature also provides benefits for overcoming kinetic barriers. Another advantage of DME compared to methanol is the lower degree of crossover due to the less polar character.

It has previously been shown that DME can be converted directly in a fuel cell with performances close to DMFC at same conditions. In the presented study an improved performance of direct DME HT-PEMFC has been achieved by optimising electrode preparation procedure and MEA assembling. Vapour fed fuel cells utilizing MEAs composed of $\mathrm{H}_{3} \mathrm{PO}_{4}$-doped $\mathrm{PBI}$ membrane with $\mathrm{Pt} / \mathrm{C}$ cathode and $\mathrm{Pt}-\mathrm{Ru} / \mathrm{C}$ anode had peak power densities as high as $79 \mathrm{~mW} / \mathrm{cm}^{2}$ at $200{ }^{\circ} \mathrm{C}$ and ambient pressure with air as oxidant. The open circuit voltages (OCV) for DME operation were 50 to $100 \mathrm{mV}$ higher than for methanol operation on the same cells, confirming the theory of less fuel crossover. Influence of anode catalyst metal loading on the fuel cell performance has been investigated. It was found that the optimum loading was $4 \mathrm{mg}$ metal per $\mathrm{cm}^{2}$, where the thickness of the catalyst layer outweighs the benefit of the increased amount of catalytically active material. 
91 - Poster session

\title{
Catalyst coated polybenzimidazole-membrane based assemblies for high temperature PEMFC
}

\author{
$\underline{\text { Nicolas Sephane }}^{\mathrm{a}}$, Nicolas Donzel $^{\mathrm{g}}$, Julien Bernard d'Arbigny ${ }^{\mathrm{h}}$, Marc Dupont ${ }^{\mathrm{i}}$, Yannig Nedellec $^{\mathrm{j}}$, \\ Deborah Jones ${ }^{k}$, Jacques Roziere', \\ ${ }^{\mathrm{a}} \mathrm{CNRS}$-Univ. Montpellier 2 (deborah.jones@univ-montp2.fr), ${ }^{9} \mathrm{CNRS}$-Univ. Montpellier 2, ${ }^{\mathrm{h}} \mathrm{CNRS}$-Univ. Montpellier 2, \\ 'CNRS-Univ. Montpellier 2, ${ }^{\mathrm{i}} \mathrm{CNRS}$-Univ. Montpellier $2,{ }^{\mathrm{k}} \mathrm{CNRS}$-Univ. Montpellier 2, $\mathrm{C}$ RSS-Univ. Montpellier 2,
}

$\mathrm{H}_{3} \mathrm{PO}_{4}-\mathrm{PBI}$ membranes are generally integrated into an assembly using gas diffusion electrodes. In the present work, highly acid doped and cross-linked polybenzimidazole membranes have been used as substrates for catalyst coated membrane (CCM) preparation. Inks were prepared using Hispec Pt/C catalysts and, in a first stage, Nafion ionomer dispersion, were transferred by decal to each of the membrane surfaces, and the CCM assembled with a Sigracet gas diffusion layer. For the purposes of comparison, catalyst coated substrates were similarly prepared by transfer of the catalyst ink to gas diffusion layers. The same catalyst loadings were used in each case. The membrane electrode assemblies (MEAs) have been characterized in a fuel cell operating at high temperatures on hydrogen/oxygen for $5 \mathrm{~cm}^{2}$ active area, and on hydrogen/air for $25 \mathrm{~cm}^{2}$ active areas and the results compared to those obtained using MEAs prepared by spraying catalyst ink containing $\mathrm{PBI}$ on both sides of a PBI membrane, which was then doped by soaking in $\mathrm{H}_{3} \mathrm{PO}_{4}$. A third series of MEAs incorporates a PFSA/PBI ionomer, prepared as a dispersion having a single, narrow particle size population as characterized by light scattering, in the catalyst layers. The influence of the PFSA/PBI ratio on particle size distribution and on fuel cell performance was investigated. The methodology for preparation of $\mathrm{H}_{3} \mathrm{PO}_{4}$ - $\mathrm{PBI}$-based CCMs, and the effect of catalyst layer composition on fuel cell performance and durability of the final MEAs will be described. 
92 - Poster session

\section{High Temperature Polymer Electrolyte Membrane Fuel Cells - Performance and degradation}

Thomas Steenberg $^{\mathrm{a}}$, Hans Aage Hjuler ${ }^{\mathrm{g}}$, Carina Terkelsen ${ }^{\mathrm{h}}$, Hector R. García ${ }^{\mathrm{i}}$, Maria T. R. Sánches ${ }^{\mathrm{j}}$, Lars Nilausen Cleemann ${ }^{k}$, Jens Oluf Jensen',

a'Danish power Systems (ts@daposy.dk), ${ }^{9}$ Danish Power Systems, hDanish Power Systems, 'Danish Power Systems, 'DTU Energy Conversion, ${ }^{k}$ DTU Energy Conversion, 'DTU Energy Conversion,

Polybenzimidazole (PBI) membranes doped with phosphoric acid have been demonstrated to be the most successful system to achieve high temperature operation of proton exchange membrane fuel cells (PEMFC). Fuel cell technologies based on this membrane system have been demonstrated with operational features including no need for gas humidification, easy airflow and temperature control, simplified cooling, enhanced tolerance to fuel impurities and reasonable long-term durability. High Temperature Polymer Electrolyte Membrane Fuel Cells (HTPEM) are based on phosphoric acid doped PBI membranes using platinum catalysts on carbon electrode support (MEA) at operating temperatures in the range $140-180{ }^{\circ} \mathrm{C}$. Improvements in performance and manufacturing processes for the MEA are being developed, and the establishment of a pilot scale production is in progress at Danish Power Systems. In this communication we present the latest results on performance and durability. 
93 - Poster session

\title{
Effect of humidity on HT-PEM fuel cell manufacture in all steps from PBI synthesis to MEA storage
}

\author{
Carina Terkelsen $^{\mathrm{a}}$, Thomas Steenberg ${ }^{\mathrm{g}}$, Hans Aage Hjuler ${ }^{\mathrm{h}}$, Thorsten Holst ${ }^{\mathrm{i}}$, Hector R. García ${ }^{\mathrm{j}}$, \\ aDanish Power Systems (ct@daposy.dk), 'Danish Power Systems, "Danish Power Systems, 'Danish Power Systems, \\ 'Danish Power Systems,
}

Water management is normally an issue connected with the operation of Low Temperature Polymer Electrolyte Membrane fuel cells and not High Temperature Polymer Electrolyte Membrane (HT-PEM) fuel cells. However, during the manufacturing processes humidity plays a large role in the steps from the synthesis of polybenzimidazole (PBI) over membrane casting to membrane doping and on Membrane Electrode Assembly (MEA) storage. The synthesis of meta-polybenzimidazole from 3,3'-diaminobenzidine tetrahydrochloride (DAB) and isophatalic acid is a step growth polycondensation and thereby very dependent on having a 1:1 stoichiometric relation between the two monomers. The content of water in the DAB is therefore a very crucial parameter to measure in order to obtain a high molecular weight of the synthesized PBI. Thermo Gravimetric Analyses have been performed on PBI showing it to be a water absorbing substance. This ability influences both PBI's dissolution properties in dimethylacetamide as well as the obtained doping level of the PBI membranes. Results relating the solubility, mechanical properties and doping level to the humidity will be presented. The ability to absorb water influences also the membrane and MEA storage. Even when doped with PA the PBI still takes up moisture from the air causing a dilution of the PA over time and thus both influences the performance and mechanical properties of the MEA. 
94 - Poster session

\section{Energy Dispersive X-ray Analysis used to quantify the Phosphoric Acid Doping Level in Polybenzimidazole based Fuel Cells}

Thorsten Holst $^{\mathrm{a}}$, Thomas Steenberg ${ }^{\mathrm{g}}$, Hans Aage Hjuler ${ }^{\mathrm{h}}$, Carina Terkelsen ${ }^{\mathrm{i}}$, Hector R. García ${ }^{\mathrm{j}}$, Jens Oluf Jensen ${ }^{k}$, Lars Nilausen Cleemann', Qingfeng Li ${ }^{m}$, Niels J. Bjerrum ${ }^{n}$,

a'Danish power Systems (th@daposy.dk), ${ }^{9}$ Danish Power Systems, " $D a n i s h$ Power Systems, 'Danish Power Systems, ${ }^{\mathrm{j}}$ Danish Power Systems, ${ }^{\mathrm{D}}$ DTU Energy Conversion, 'DTU Energy Conversion, ${ }^{\mathrm{m}} \mathrm{DTU}$ Energy Conversion, ${ }^{\mathrm{n}} \mathrm{DTU}$

Energy Conversion,

In High Temperature Polymer Electrolyte Membrane (HT-PEM) fuel cells, the membrane is made of polybenzimidazole $(\mathrm{PBI})$. The necessary proton conductivity of the membrane is ensured by doping it with phosphoric acid (PA). The amount of PA contained in the membrane is described by the doping level (DL), which is the number of PA molecules per repeating unit of PBI. It is important for the HT-PEM fuel cell performance that the doping level is high from the beginning and that it will remain high during the lifetime of the cell. Therefore, it is desirable to have a method, which can quantify the membrane's doping level for example as a post mortem analysis after a durability test in order to monitor a possible loss of PA over time. We have used Energy Dispersive X-ray Spectroscopy (EDS) to establish the amount of PA in the Membrane Electrode Assembly (MEA) structure. Elemental analysis of the membrane's content of phosphorus and oxygen (PA) relative to the carbon and nitrogen content $(\mathrm{PBI})$ yields indications about the doping level. Samples were prepared by making a cross-section cut through the MEA structure. Argon ion milling was used to gently do a final polishing of the cross-sectional surface, before the sample entered the scanning electron microscope. The EDS spectra were acquired from a $10 \times 10 \mu \mathrm{m}^{2}$ area in the center of the 30-60 $\mu \mathrm{m}$ thick membranes. A simple model of the membrane's molecular composition and a least-square fitting procedure are used to subtract information about the doping level. On average, the model deviates no more than $1 \%$ from the element content measured by EDS. Doping levels in the range 5-8 with an uncertainty of \pm 0.5 were measured. Even for a $10 \mathrm{~cm}^{2}$ HT-PEM fuel cell, which has been running at $200 \mathrm{~mA} / \mathrm{cm}^{2}$ for more than 10,000 hours, the doping level was measured to $4.9 \pm 0.5$. This fairly high value may indicate that loss of PA from the membrane area is unlikely to be the primary contributor to fuel cell degradation. Discussion of the method and its limitations will be presented. 


\title{
Low Energy X-ray Imaging used to quantify the Large-Area Thickness Variation of the Catalyst Loading on Carbon Cloth based Electrodes for Fuel Cells
}

\author{
Thorsten Holst $^{\mathrm{a}}$, Thomas Steenberg ${ }^{\mathrm{g}}$, Hans Aage Hjuler ${ }^{\mathrm{h}}$, Carina Terkelsen ${ }^{\mathrm{i}}$, Hector R. García ${ }^{\mathrm{j}}$, \\ ${ }^{a}$ Danish power Systems (th@daposy.dk), ${ }^{9}$ Danish Power Systems, 'Danish Power Systems, 'Danish Power Systems, \\ 'Danish Power Systems,
}

Fuel cells based on polymer electrolyte membranes often have micro-porous carbon cloth electrodes. The necessary catalytic activity is established by coating the carbon cloth surface with a suitable catalyst material, typically nano-sized platinum particles imbedded onto a highsurface area carbon structure. From a production point-of-view, it is highly desirable to be able to investigate if the catalyst layer is distributed evenly over the whole electrode area of the fuel cell. In this study, we introduce an X-ray imaging technique, which can be used to characterize the thickness variation of the Pt-loaded catalyst over a large area of, say, 20x20 $\mathrm{cm}^{2}$. Low energy $\mathrm{X}$-ray $(<25 \mathrm{kV})$ imaging is characterized by a high level of grey-scale contrast. The image contract is mainly provided by the heavy element attenuation of the $X$ rays, in this case Pt being the heavy element. This makes this technique particularly suited for revealing even minute changes in the electrode's Pt-loading. A spatial image resolution in the sub-millimeter range is easily achieved, which also helps mapping out some coating artifacts. In this work, a spray coater with four ultrasonic nozzles was used to spray a Pt/C-based catalyst ink onto a $200 \mathrm{~cm}$ long, $20 \mathrm{~cm}$ wide, rotating carbon cloth belt. The ink consisted of a commercial Pt catalyst, dispersed in formic acid (purity > $99 \%$ ). Typical Pt loading levels investigated ranged from $0.2-1.3 \mathrm{mg} \mathrm{Pt} / \mathrm{cm}^{2}$. A linear relationship between the $\mathrm{Pt}$ loading and the grey scale level of the digital X-ray image was established. This technique was used to characterize and subsequently optimize the nozzle position, both in a stationary spray set-up and in a transversely moving set-up, where the nozzles were moved during the spraying process in order to average-out the nozzle's individual plume profiles. In conclusion, it was possible to obtain a thickness variation of the Pt loading $< \pm 5 \%$ over the whole $200 \times 20 \mathrm{~cm}^{2}$ area. This will result in better electrode reproducibility and catalyst utilization in fuel cell production. 


\section{Semi-empirical modeling in a proton exchange membrane fuel cell system - Membrane Electrode Assembly (MEA to MEA) variation}

Hector R. García ${ }^{\mathrm{a}}$, Thomas Steenberg ${ }^{g}$, Hans Aage Hjuler ${ }^{\mathrm{h}}$, Thorsten Holst ${ }^{\mathrm{i}}$, Carina Terkelsen ${ }^{\mathrm{j}}$,

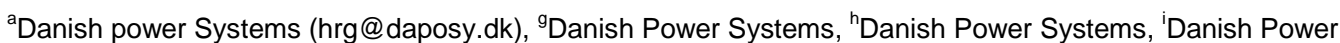
Systems, 'Danish Power Systems,

Danish Power Systems is making great efforts to manufacture and scale up the main component in HT-PEM fuel systems, the membrane electrode assembly (MEA). The manufacturing process consists of a number of stages in order to reach the required performance of the final MEA. One important technique for quality control tests is related to the interpretation of the data from polarization curves. Semi-empirical modeling using polarization data can reveal the cause of MEA to MEA variation, and thereby MEA and batch variation can be minimized. Voltage at open circuit voltage (OCV), Tafel slope, ohmic resistance and exchange current density were modeled to quantify different losses present in a HT-PEM MEA. To prove and validate the mathematical model applied, different batches of $25 \mathrm{~cm}^{2}$ MEAs were manufactured. A batch of ten MEAs were manufactured with a loading of $0.77 \mathrm{mg} \mathrm{Pt} / \mathrm{cm}^{2}$ using PBI membranes doped with phosphoric acid (doping level of 7.4 and 40 $\mu \mathrm{m}$ thickness). Correlation between the model and overall performance of the MEA was investigated. Furthermore, four different batches of MEAs were manufactured with electrodes with different Pt loadings $\left(0.63 \mathrm{mg} / \mathrm{cm}^{2}, 0.77 \mathrm{mg} / \mathrm{cm}^{2}, 1.12 \mathrm{mg} / \mathrm{cm}^{2}\right.$ and $\left.1.45 \mathrm{mg} / \mathrm{cm}^{2}\right)$ were tested and modeled. The dependence of the kinetic parameters of the model with the platinum loading sprayed on the electrode was evaluated. Three other batches were manufactured with different membrane thicknesses, $(20 \mu \mathrm{m}, 40 \mu \mathrm{m}$ and $80 \mu \mathrm{m})$. The results show that membrane resistance is the main contributor to the ohmic losses present in the fuel cell. Quantification of the fuel cell crossover by using electrochemical hydrogen crossover technique was performed in a fresh and deliberately perforated MEA, respectively. This semiempirical model has been found to give an excellent fit with the results of real HT-PEM fuel cells. 


\title{
In-depth understanding of cathode mechanisms and catalyst support role in the polymer electrolyte fuel cells (PEMFCs)
}

\author{
Merzougui Belabbes ${ }^{\mathrm{a}}$, Abdouelilah Hachimi ${ }^{\mathrm{b}}$, \\ ${ }^{a}$ Center of Nanotechnology (CENT) \& Department of Chemistry, KFUPM, Dhahran 31261 Saudi Arabia. \\ (belabbes@kfupm.edu.sa), ${ }^{\text {bPost-Doc, }}$
}

\section{Summary}

The poster focuses on the latest research results related to cathode mechanisms and role of catalysts support in PEMFCs. For the first time, cathode voltage behavior during start-up will be presented.

PEMFCs cathode is always subjected to an environment consisting of two harsh processes; the first one is associated with chemical species, such as peroxides and peroxide radicals, produced as intermediates during oxygen reduction reaction (ORR). The lifetime of these chemical species depends strongly on catalyst, catalyst support, acidity level, and cathode voltage. The second process is basically an electrochemical process and is related to the excursion of cathode potential during start-stop cycling and anode starvation. This potential cycling can lead, if not well managed, to a dramatic loss in catalyst performance as results of material degradation [1-3]. In this poster presentation, detailed studies on PEMFCs cathode mechanisms will be presented. This includes cathode voltage behaviour during start-stop cycling, effect of potential cycling on catalyst surface area, and effect of metal oxide as catalyst support on catalyst activity and stability.

\section{Reference:}

[1] B. Merzougui, and S. Swathirajan, "Rotating Disc Electrode Investigation of Fuel Cell Catalyst Degradation Due to Potential Cycling in Acid Electrolyte", J. Electrochem. Society, 153(12) A2220-A2226 (2006).

[2] Mei Cai, Martin Ruthkosky, B. Merzougui, and Swathy Swathirajan, Michael Balogh, Se $\mathrm{H}$. Oh, "Investigation of Thermal and Electrochemical Degradation of Fuel Cell Catalysts", J. Power Sources 160, 977-986 (2006).

[3] Ion Halalay, Swathy Swathirajan, Belabbes Merzougui, Michael Balogh, Gregory Garabedian, and Michael Carpenter, "Anode Materials for Mitigating Hydrogen Starvation Effects in PEM Fuel Cells", J. Electrochem. Soc., 158 (3) B313-B321 (2011). 
98 - Poster session

\title{
Electrospun Nanofibres As Novel Support Materials For PEMFC Electrodes
}

\author{
Sara Cavaliere $^{\mathrm{a}}$, Julia Savych $^{\mathrm{g}}$, Surya Subianto ${ }^{\mathrm{h}}$, Deborah Jones ${ }^{\mathrm{i}}$, Jacques Roziere ${ }^{\mathrm{j}}$, \\ ${ }^{a}$ CNRS-Univ. Montpellier 2 (sara.cavaliere@univ-montp2.fr), ${ }^{9} \mathrm{CNRS}-U n i v$. Montpellier 2, ${ }^{\mathrm{h}} \mathrm{CNRS}$-Univ. Montpellier 2, \\ ${ }^{i}$ CNRS-Univ. Montpellier 2, 'CNRS-Univ. Montpellier 2,
}

Carbon-support corrosion is significantly accelerated at higher temperature operation during start/stop cycles, leading to cathode thinning, which increases oxygen diffusion resistances and voltage losses, especially at high current densities. This effect can be mitigated by replacing conventional carbon supports either by cathode catalyst support materials based on graphitised carbons or by more corrosion resistant electronically conducting non-carbon supports. In recent work, we have developed experimental approaches leading to the elaboration of anode and cathode support materials having a range of morphologies ranging from microspherical to nanorod, nanofibrous and nanotubular. 1D morphology can improve the interface properties as well as the electronic conductivity of the support materials with overall improvement in performance and lifetime. The synthesis of aligned or randomly organised metal oxide nanofibre or nanotube mats by electrospinning is an extremely versatile approach. It allows preparation of a broad range of chemical compositions, either by incorporation of appropriate precursors in the synthesis medium, or by suitable posttreatments, for example by conversion to a corresponding (oxy)nitride or carbide, and investigation of this impact of composition and process conditions on support conductivity. Various tin and titanium oxide nanofibre and nanotube materials have been elaborated, and the effect of the incorporation of niobium on structural, textural and electrical properties has been investigated by SEM-EDX, TEM, XRD, Raman spectroscopy, XPS, $\mathrm{N}_{2}$ adsorption/desorption, cyclic voltammetry and chronampometry. The esistance of oxide materials to electrochemical corrosion is significantly improved compared to conventional carbon. Samples were catalysed by deposition of platinum nanoparticles (polyol method) and also by an original single step route based on electrospinning. This allows tuning of the metal particle size through processing conditions and can be extended to in situ preparation of bi/trimetallic catalysts. 
99 - Poster session

\title{
Comparison of Proton Exchange Membranes Degradation Rates Between Accelerated and Performance Tests
}

\author{
Marianne Rodgers ${ }^{\mathrm{a}}$, R. Paul Brooker ${ }^{\mathrm{g}}$, Nahid Mohajeri ${ }^{\mathrm{h}}$, Leonard J. Bonville ${ }^{\mathrm{i}}$, H. Russell Kunz ${ }^{\mathrm{j}}$, Darlene \\ K. Slattery ${ }^{k}$, James M. Fenton!, \\ aUniversity of Central Florida-Florida Solar Energy Center (mrodgers@fsec.ucf.edu), ${ }^{9}$ University of Central Florida- \\ Florida Solar Energy Center, "University of Central Florida-Florida Solar Energy Center, 'University of Central Florida- \\ Florida Solar Energy Center, 'University of Central Florida-Florida Solar Energy Center, ${ }^{\mathrm{k}}$ University of Central Florida- \\ Florida Solar Energy Center, 'University of Central Florida-Florida Solar Energy Center,
}

To establish a universal procedure to determine and predict the durability of components of proton exchange membrane fuel cells in practical applications, it is desirable to assess the extent to which accelerated stress tests (ASTs) amplify cell degradation compared to lifetime tests. This study compares the effects of standard performance testing and accelerated stress testing on catalyst coated membrane (CCM) degradation. The performance evaluation tests (PETs) involved $184 \mathrm{~h}$ total operation, including performance tests at 80 to $120 \mathrm{oC}$ and 35 to $100 \%$ relative humidity $(\mathrm{RH})$, as well as a stability test for $64 \mathrm{~h}$ at $95 \mathrm{oC} / 83 \% \mathrm{RH}, 400$ $\mathrm{mA} / \mathrm{cm} 2$. Besides testing performance, an additional goal of the PETs was that they would not significantly degrade the CCMs. The ASTs involved operation at $90 \mathrm{oC} / 30 \% \mathrm{RH}$ and open circuit voltage $(\mathrm{OCV})$ for $100 \mathrm{~h}$. The CCMs all contained NRE211 ${ }^{\circledR}$ membranes. The electrodes had four configurations: 1) Pt/C + $32 \mathrm{wt} \% 1100$ equivalent weight (EW) Nafion, 2) $\mathrm{PtCo} / \mathrm{C}+32 \mathrm{wt} \% 1100 \mathrm{EW}$ Nafion, 3) Pt/C + 28\% $825 \mathrm{EW} 3 \mathrm{M}$, and 4) $\mathrm{PtCo} / \mathrm{C}+28 \mathrm{wt} \% 825$ EW 3M. Similar decay modes, including fluoride emission, membrane thinning, voltage decay, loss in electrochemically active surface area (ECA), increase in $\mathrm{H} 2$ crossover (x-over), and $\mathrm{Pt}$ deposition in the membrane were observed for both types of tests. The ASTs generally resulted in accelerated decay modes. When comparing the durability for each type of $\mathrm{CCM}$, it was clear that using $\mathrm{PtCo} / \mathrm{C}$ rather than $\mathrm{Pt} / \mathrm{C}$ in the electrode improved durability by an order of magnitude, which was explained in terms of no Pt band formation for cells containing $\mathrm{PtCo} / \mathrm{C}$. The ionomer $\mathrm{EW}$ and loading in the electrode did not have a strong effect on the cell durability for either test. The decay rates of the PETs in the present study were generally much higher than that of the lifetime tests found in the literature, likely because the latter are usually steady state tests, while the former included several different temperatures and multiple performance curves. The voltage decay rates of the PETs in the present study were similar to those from drive cycle tests in the literature. Although the PET in the present study is an excellent method of determining performance while minimizing degradation, and results in similar degradation rates as those from drive cycle tests, it is not representative of an automotive drive cycle. Adopting a particular drive cycle test as a baseline test would serve as a benchmark for future work. 
100 - Poster session

\title{
Effect of Membrane Equivalent Weight on Degradation Under Accelerated Stress Conditions
}

\author{
$\underline{\text { Marianne Rodgers }}{ }^{\mathrm{a}}$, Benjamin P. Pearman ${ }^{\mathrm{g}}$, Nahid Mohajeri ${ }^{\mathrm{h}}$, Leonard J. Bonville ${ }^{\mathrm{i}}$, Darlene K. Slattery \\ j, James M. Fenton ${ }^{k}$, \\ aUniversity of Central Florida-Florida Solar Energy Center (mrodgers@fsec.ucf.edu), ${ }^{9}$ University of Central Florida- \\ Florida Solar Energy Center, "University of Central Florida-Florida Solar Energy Center, 'University of Central Florida- \\ Florida Solar Energy Center, 'University of Central Florida-Florida Solar Energy Center, ${ }^{\mathrm{k}}$ University of Central Florida- \\ Florida Solar Energy Center,
}

The equivalent weight (EW) of membranes has a large effect on their properties and can impact performance and durability. For example, for perfluorosulfonic acid membranes, crystallinity and water content increase with increases in EW, while glass transition temperature decreases with increases in EW. The length of the sulfonic acid side chain also impacts membrane properties. It has been shown that perfluorosulfonic acid membranes with shorter sulfonic acid side chains result in higher crystallinity, higher glass transition temperature, similar gas permeability, lower water content, and lower proton conductivity than membranes with longer sulfonic acid side chains for a given EW. Although many reports have shown improved cell performance for membranes with low EW and shorter side chains, the impact of EW and side chain length on cell durability is not well understood. Because side chain attack by radicals formed during fuel cell operation is a major source of membrane degradation, it is reasonable to hypothesize that membranes with lower EW and, therefore, more sulfonic acid side chains, would have lower durability. This study evaluates membrane degradation for cells containing PFSA membranes with 750, 950, and $1100 \mathrm{EW}$. The $750 \mathrm{EW}$ membrane contained short sulfonic acid side-chains while the 950 and $1100 \mathrm{EW}$ membranes were Nafion ${ }^{\circledR}$-based with long sulfonic acid side chains. Membranes were tested in fuel cells for $100 \mathrm{~h}$ under open circuit voltage, at 90 oC/30\% relative humidity. Diagnostic tests conducted on the cells included hydrogen crossover (x-over), fluoride emission, catalyst electrochemical surface area (ECA), post-test membrane scanning electron microscopy/transmission electron microscopy evaluation, and defect identification in membranes. Although the $750 \mathrm{EW}$ cell had the largest change in x-over, the $950 \mathrm{EW}$ cell had higher decay modes in other metrics, including fluoride emission, voltage decay, loss in ECA, and loss in cell performance. In all cases, the $1100 \mathrm{EW}$ cell showed the lowest degradation. This has been explained in terms of degree of crystallinity, which impacts the mechanical stability of the membrane and number of side chains. 


\title{
In situ and ex situ monitoring of the mitigation of membrane degradation by radical scavengers and hydrogen peroxide decomposition catalysts
}

\author{
Marta Zaton $^{\mathrm{a}}$, Bénédicte Prelot ${ }^{\mathrm{g}}$, Yannig Nedellec ${ }^{\mathrm{h}}$, Deborah Jones ${ }^{\mathrm{i}}$, Jacques Roziere ${ }^{\mathrm{j}}$, \\ ${ }^{\mathrm{a}} \mathrm{CNRS}$-Univ. Montpellier 2 (zatonmarta@gmail.com), ${ }^{9} \mathrm{CNRS}$-Univ. Montpellier 2, ${ }^{\mathrm{h}} \mathrm{CNRS}$-Univ. Montpellier 2, \\ ${ }^{\mathrm{i}} \mathrm{CNRS}$-Univ. Montpellier 2, ${ }^{\mathrm{j}} \mathrm{CNRS}$-Univ. Montpellier 2,
}

A comparison is made of the effectiveness of manganese and cerium species in mitigating perfluorosulfonic acid membrane degradation when incorporated throughout the membrane or preferentially at its anode or cathode side, and in ionic and oxide forms. Mn and Ce have been introduced into Nafion-212 membranes by ion exchange, and cerium and manganese oxides as embedded nanofibre layers at one or both sides of the membrane Ion chromatography was used to investigate the kinetics of transport of $\mathrm{Mn}^{2+}$ and $\mathrm{Ce}^{3+}$ ions through ion-exchange membranes. Membranes were immersed in corresponding salt solutions at various temperatures, and the changes in concentration of $\mathrm{Mn}^{2+}$ and $\mathrm{Ce}^{3+}$ were monitored over time. The detection limit of this method is $<0.001 \mathrm{mM}(50 \mathrm{ppb})$. In the context of the stability of these ions in a hydrated membrane, one of the most significant findings was the higher diffusivity of $\mathrm{Mn}^{2+}$ compared to $\mathrm{Ce}^{3+}$. Membranes were prepared having a range of degrees of Mn or Ce ion exchange, and SEM-EDX and XPS used to map the ion content across the membrane thickness. Membrane conductivity and water content were determined, and membranes with $\leq 10 \%$ of the total capacity ion exchanged with $\mathrm{Mn}$ or Ce were used in vapour and liquid phase Fenton testing, and open circuit voltage hold testing at $80^{\circ} \mathrm{C}$ and $13 \% \mathrm{RH}$. Membrane chemical degradation was assessed by the fluoride emission rate (FER). Fresh and aged MEAs were submitted to XPS analysis to determine the oxidation state of the ionic species and monitor the ion concentration profile. The significant reduction in FER under OCV which is observed with $\mathrm{Mn}$ and Ce ion modified Nafion-212 will be compared with that obtained using MEAs comprising manganese and cerium oxide composite membranes, with the oxides embedded within the membrane as a layer either preferentially at the anode or cathode side, or at both sides. These observations will be related to the performances losses and migration or elution of metal ions, and to evolution of the oxidation state of the metallic species, and the results used to provide further guidance on materials strategies to mitigate membrane chemical degradation. 


\title{
102 - Poster session
}

\section{Application of TGA Techniques to Analyze the MEA Degradation}

\author{
Jong Hyun Jang ${ }^{a}$, Hye-Jin Lee ${ }^{g}$, Min Kyung Cho ${ }^{\text {h }}$, Hyoung-Juhn Kim ${ }^{\mathrm{i}}$, EunAe Cho ${ }^{\mathrm{j}}$, Soo-Kil Kim ${ }^{\mathrm{k}}$, Dirk \\ Henkensmeier', Sung Jong Yoo ${ }^{\mathrm{m}}$, Suk Woo Nam ${ }^{\mathrm{n}}$, Tae-Hoon Lim ${ }^{\circ}$, \\ ${ }^{a}$ Korea Institute of Science and Technology (KIST) (jonghyun.jang@gmail.com), ${ }^{9}$ Korea Institute of Science and \\ Technology (KIST), "Korea Institute of Science and Technology (KIST), 'Korea Institute of Science and Technology \\ (KIST), 'Korea Institute of Science and Technology (KIST), ${ }^{\text {K}}$ Chung-Ang University, 'Korea Institute of Science and \\ Technology (KIST), ${ }^{m}$ Korea Institute of Science and Technology (KIST), ${ }^{n}$ Korea Institute of Science and Technology \\ (KIST), ${ }^{\circ}$ Korea Institute of Science and Technology (KIST),
}

\section{Summary}

Thermogravimetric analysis (TGA) was used as a novel tool for post-analysis of PEMFC MEAs, and its usefulness was confirmed by analyzing degraded MEA samples.

For the commercialization of medium and high temperature PEMFCs, further development to increase their durability and reduce the material cost is highly required. During operation, the degradation of MEAs and stacks are monitored by various in-situ techniques, and, after single-cell/stack operation, post-analyses are carried out to elucidate the detailed degradation mechanism of each component in the MEAs and stacks. In this study, thermogravimetric analysis (TGA) was used as a novel tool for post-analysis of PEMFC MEAs, and its usefulness was confirmed by analyzing degraded MEA samples. Previously, TGA has been primarily used to evaluate the thermal stability of the polymer membranes and the carbon support. As a post-analysis tool, TGA is expected to provide information for the compositional and structural degradation of PEMFC MEAs. Analysis of catalyst layer (CL) samples with various Nafion ionomer contents quantitatively confirmed that the Nafion ionomer decomposed first at around $320{ }^{\circ} \mathrm{C}$ and the support carbon at around $410{ }^{\circ} \mathrm{C}$. For the degradation analysis of MEAs, the amount variation of components, including platinum (Pt) and attached gas diffusion layer (GDL), and the degree of Pt agglomeration could be evaluated from weight changes and DTG peak shifts (the platinum activation effect), respectively. As the compositional and structural variations can be conveniently analyzed in a single measurement, the TGA technique is expected to be very useful as an ex-situ tool for preliminary evaluation of degraded PEMFC MEAs. 
103 - Poster session

\title{
Quantification of ionomer in solution by 19F NMR in order to follow organic phase degradation in active layers
}

\author{
Assma El Kaddouri ${ }^{a}$, Lara Perrin ${ }^{b}$, Bruno Jean ${ }^{c}$, Eddy Moukheiber ${ }^{d}$, Lionel Flandin ${ }^{e}$, Corine Bas ${ }^{f}$, \\ a'LEPMI - LMOPS UMR 5279 (assma.el-kaddouri@univ-savoie.fr), 'bEPMI - LMOPS UMR 5279, 'CERMAV - \\ UMR5301, 'LEPMI - LMOPS UMR 5279, 'LEPMI - LMOPS UMR 5279, 'LEPMI - LMOPS UMR 5279,
}

In order to enhance the lifetime of polymer electrolyte membrane fuel cell (PEMFC), many works were achieved to understand the ageing of membrane electrode assembly (MEA)under fuel cell operation. Membrane, catalyst and carbon support degradations during in-situ/or exsitu tests were reported and their mechanisms are already established. However, the active layer binder that is part of triple boundaries phase and plays a main role in proton conductivity,could also be subject to degradation. Therefore, the understanding of the ionomer behavior during fuel cell operation is necessary. According to literature[1], one way to characterize the ionomer degradation is to extract the organic binder by soxhlet extraction and then to analyse it by 19F NMR. In this work, we propose to quantify commercial Nafion solutions by NMR analysis. First results obtained, on aqueous and alcohol/water mixture Nafion solutions, showed an underestimation of the polymer amount at room temperature. These results will be discussed in terms of Nafion aggregated states. Finally, a specific $19 \mathrm{~F}$ NMR protocol will be proposed in order to evaluate the perfluorosulfonic acid concentration in solution.

1. Chatenet, et al., The (electro)catalystmembrane interface in the Proton Exchange Membrane Fuel Cell: Similarities and differences with non-electrochemical Catalytic Membrane Reactors. Catalysis Today, 2010. 156(3-4): p. 76-86. 
104 - Poster session

\title{
Fuel Cell Catalyst degradation mechanisms - a study on size-selected Platinum nanoclusters
}

\author{
$\underline{\text { M. Röefzaad }^{a}}{ }^{\text {, M. Nesselberger }}{ }^{g}$, F. Schweinberger ${ }^{\text {h }}$, A.S. Crampton ${ }^{i}$, C. J. Ridge ${ }^{j}$, U. Heiz $^{k}$, Matthias \\ Arenz', \\ a University of Copenhagen (m.roefzaad@chem.ku.dk), ${ }^{9}$ University of Copenhagen, ${ }^{\mathrm{h}} \mathrm{Technical}$ University Munich, \\ 'Technical University Munich, 'Technical University Munich, ${ }^{\mathrm{k}}$ Technical University Munich, 'University of Copenhagen,
}

The main fundamental problems of polymer electrolyte membrane fuel cells (PEMFCs) to date are a low practical efficiency, due to the high overpotential for the oxygen reduction reaction (ORR), the high amount of noble metal catalyst in use, and the degradation of the catalyst in a fuel cell during operation. Especially to clarify the ongoing processes and the responsible factors for the degradation and therefore the loss of usable catalytic active material, is one important step to achieve long term stability of PEMFCs. In this study we used size selected Pt-Nanoclusters (NCs) supported on TEM gold grids as a model system for Fuel Cell Catalysts to address the widely discussed mechanisms of Fuel Cell Catalyst degradation. Up to now it is not clear which of the proposed mechanisms (Pt dissolution, particle migration or concomitant coalescence, particle detachment) [1,2] ], is the main responsible process. The well-defined Pt-NCs have been prepared by an ultra-high vacuum (UHV) laser vaporization source and were deposited with low kinetic energy. Samples thus prepared have been employed as working electrodes in a standard electrochemical three electrode setup, where the Pt-NCs were subjected to different treatments, such as accelerated degradation tests. TEM measurements allow a characterization of the Nanoclusters before and after the treatment concerning particle size and distribution on the support.

\section{References}

[1] R. Borup et. Al, Chem. Rev. 2007, 107, 3904.

[2] P.J. Ferreira et. Al, J. Electrochem. Soc. 2005, 152, A2256. 
105 - Poster session

\title{
Corrosion behaviour of construction materials for high temperature water electrolysers
}

\author{
Aleksey Nikiforov $^{\mathrm{a}}$, Irina Petrushina ${ }^{\mathrm{g}}$, Erik Christensen ${ }^{\mathrm{h}}$, Niels J. Bjerrum ${ }^{\mathrm{i}}$, Antonio Tomas Garcia ${ }^{\mathrm{j}}$,

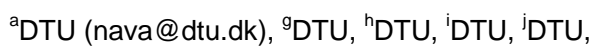

\begin{abstract}
Summary
In this work different types of corrosion resistant stainless steels, Ni-based alloys as well as titanium and tantalum were evaluated as a possible construction material for high temperature PEM cells
\end{abstract}

Elevated working temperatures in PEM water electrolysis involve increased demands for corrosion resistance of catalysts and current collectors. High temperature PEM cell cannot be built from the same materials as a cell working below $100^{\circ} \mathrm{C}$. Elevated temperatures create more severe corrosion media for components in the cell. The anodic compartment of electrolyzer is expected to have stronger corrosive conditions than cathodic due to high positive polarization in combination with presence of evolving oxygen. This demands further development of all materials from which electrolyzer cells are built. In this work different types of corrosion resistant stainless steels, Ni-based alloys as well as titanium and tantalum were evaluated as a possible metallic bipolar plate and construction material in terms of corrosion resistance in simulated conditions of high temperature proton exchange membrane (PEM) water electrolyser (HTPEMWE). All samples were proned to anodic polarisation in $85 \%$ phosphoric acid electrolyte solution. Platinum and gold plates were tested for the valid comparison. Steady-state voltammetry was used in combination with scanning electron microscopy and the energy-dispersive X-ray spectroscopy. Results show that stainless steels are the most exposed to corrosion under strong anodic polarization. Among alloys, Ni-based showed the highest corrosion resistance in the emulated media. In particular, Inconel 625 is the most promising alloy for the anodic compartment of (HTPEMWE). 
106 - Poster session

\section{Corrosion behavior of construction materials for intermediate temperature steam electrolysers}

Aleksey Nikiforov $^{\mathrm{a}}$, Irina Petrushina ${ }^{\mathrm{g}}$, Jens Oluf Jensen ${ }^{\mathrm{h}}$, Niels J. Bjerrum ${ }^{\mathrm{i}}$, aDTU (nava@dtu.dk), , DTU, 'DTU, 'DTU,

Electrolysis of water is an important process in the long term visions about the use of hydrogen as an energy carrier. Electrolytes, operating at temperatures above $100{ }^{\circ} \mathrm{C}$ under low humidification are expected to overcome several problems, met in low temperature systems. Among those challenges are water management and necessity to use noble electrocatalysts to catalyze the electrode reactions at lower temperatures. Therefore, considerable efforts have been made recently to develop such materials. The electrochemical behavior of different construction materials was studied in molten $\mathrm{KHSO}_{4}$ and $\mathrm{KHSO}_{4^{-}}$ $\mathrm{CsH}_{2} \mathrm{PO}_{4}$ electrolytes in air atmosphere. Different grades of stainless steel, nickel-based alloys, as well, as platinum, gold and tantalum electrodes were tested at elevated temperatures. Several types of commercially available stainless steels and nickel-based alloys were evaluated as possible construction materials. Their corrosion resistance was measured under simulated conditions corresponding to those in intermediate temperature steam electrolysers, using proton conducting solid electrolytes. Steady-state voltammetry was used to detect the corrosion rates and the corrosion potentials of the selected materials. It was shown that stainless steels were the least resistant to corrosion under the anodic polarization. Platinum and CVD-coated stainless steel showed superior resistance to corrosion in the selected media. The electrochemical evaluation of selected materials was performed in the cell, presented in Fig.1. 
107 - Poster session

\title{
Electrocatalysis of Oxygen Reduction on Platinum-Free Cathode Catalysts for Alkaline Membrane Fuel Cells
}

\author{
Kaido Tammeveski ${ }^{\mathrm{a}}$, Ivar Kruusenberg ${ }^{\mathrm{g}}$, Leonard Matisen ${ }^{\mathrm{h}}$, Quratul Shah ${ }^{\mathrm{i}}$, Arunachala Kannan ${ }^{\mathrm{j}}$, \\ ${ }^{a}$ Institute of Chemistry, University of Tartu (kaido@chem.ut.ee), ${ }^{g}$ Institute of Chemistry, University of Tartu, ${ }^{\text {h Institute }}$ \\ of Physics, University of Tartu, 'Fuel Cell Laboratory, Engineering Technology Department, Arizona State University, \\ ${ }^{\mathrm{j}}$ Fuel Cell Laboratory, Engineering Technology Department, Arizona State University,
}

\begin{abstract}
Summary
Carbon nanotube supported CoPc and FePc could be used as cathode catalysts in alkaline membrane fuel cells. The fuel cell performance of MEAs with CoPc/MWCNT was almost similar to that of $20 \mathrm{wt} \% \mathrm{Pt} / \mathrm{C}$.
\end{abstract}

The aim of this work was to study multi-walled carbon nanotube (MWCNT) supported cobalt phthalocyanine $(\mathrm{CoPc})$ and iron phthalocyanine $(\mathrm{FePc})$ electrocatalysts as alternative cathode materials to $\mathrm{Pt} / \mathrm{C}$ in alkaline membrane fuel cell. We have also explored the electrocatalytic activity of FePc/MWCNT and CoPc/MWCNT modified glassy carbon (GC) electrodes toward oxygen reduction using the rotating disk electrode (RDE) method. The electroreduction of oxygen has been studied on FePc/MWCNT and CoPc/MWCNT modified $\mathrm{GC}$ electrodes in $0.1 \mathrm{M} \mathrm{KOH}$. The fuel cell performance of CoPc and FePc modified MWCNTs was investigated by fabricating membrane-electrode assemblies (MEAs) using Tokuyama membrane (\# A201) and compared with unmodified MWCNT and commercial Pt/C catalysts. The results of electrochemical measurements indicated excellent electrocatalytic properties of phthalocyanine modified MWCNTs toward $\mathrm{O} 2$ reduction in alkaline media. A significant enhancement of the oxygen reduction activity was observed for FePc/MWCNT and CoPc/MWCNT catalysts as compared to acid-treated MWCNTs [1]. The number of electrons transferred per $\mathrm{O} 2$ molecule (n) at different potentials for the CoPc/MWCNT modified GC electrode was calculated from the Koutecky-Levich equation. The value of $n$ for the CoPc/MWCNT material approaches almost four and for the FePc/MWCNT material the $n$ value was close to 3 . A comparative study of fuel cell performance of the MEAs with MWCNT supported CoPc and FePc and Tanaka Kikinzoku Kogyo Pt/C cathode catalysts yielded power densities of 100,60 and $120 \mathrm{~mW} \mathrm{~cm}-2$ using $\mathrm{H}_{2}$ and $\mathrm{O}_{2}$ gases [2]. The results obtained in this work show that MWCNT supported CoPc and FePc catalysts possess excellent electrocatalytic activity toward oxygen reduction in alkaline solution and could be used as alternative cathode catalysts in alkaline membrane fuel cells. The fuel cell performance of the MEAs with Co phthalocyanine/MWCNT cathode was found to be almost similar to the commercial $20 \mathrm{wt} . \% \mathrm{Pt} / \mathrm{C}$ catalyst using $\mathrm{H} 2$ and $\mathrm{O} 2$ gases [2].

\section{References}

[1] I. Kruusenberg, N. Alexeyeva, K. Tammeveski, Carbon 47 (2009) 651.

[2] I. Kruusenberg, L. Matisen, Q. Shah, A.M. Kannan, K. Tammeveski, Int. J. Hydrogen Energy 37 (2012) 4406. 


\title{
Hydrogen Production from Methanol for High Temperature PEM Fuel Cells using a Catalytic Reformer
}

\author{
Jakob Engbaek ${ }^{\mathrm{a}}$, Rasmus Munksgård Nielsen ${ }^{\mathrm{b}}$, Mads Bang ${ }^{\mathrm{g}}$, Peder Lund Rasmussen ${ }^{\mathrm{h}}$, \\ ${ }^{\mathrm{a}}$ Danish Technological Institute (ramn@dti.dk), ${ }^{\mathrm{b}}$ Danish Technological Institute, ${ }^{9}$ SerEnergy A/S, ${ }^{\mathrm{h}}$ SerEnergy A/S,
}

\section{Summary}

A catalyst for producing hydrogen with methanol/water as fuel for a high temperature PEM fuel cell is investigated. Special focus has been on the content of $\mathrm{CO}$ in the produced gas.

One of the major challenges for commercializing PEM fuel cells is the handling of the fuel. In most applications it is difficult to use hydrogen gas as direct fuel. The most obvious alternative is to use methanol. The main challenge is then to convert this into hydrogen. We have investigated conversion of a methanol into hydrogen using an external catalytic reformer. If pure methanol is used a high content of $C O$ is produced, see (1). This will lead to devastating degradation of the MEA, thus water is added to the methanol mixture, see (2). This methanol steam reforming process leads to a production gas with a lower, but not insignificant, $\mathrm{CO}$ content.

$$
\begin{aligned}
& \mathrm{CH}_{3} \mathrm{OH} \rightarrow 2 \mathrm{H}_{2}+\mathrm{CO} \\
& \mathrm{CH}_{3} \mathrm{OH}+\mathrm{H}_{2} \mathrm{O} \rightarrow 3 \mathrm{H}_{2}+\mathrm{CO}_{2}
\end{aligned}
$$

The steam reforming reaction, which is run at approximately $250-300^{\circ} \mathrm{C}$, is strongly endotherm. The energy needed for the reaction is ideally extracted from the fuel cell stack optimizing the overall efficiency. Since the HT fuel cell is operating at approximately $180^{\circ} \mathrm{C}$ additional energy normally needs to be added to reach the operating temperature of the catalytic converter. It is desirable to find a catalyst that can carry out the steam reforming at a temperature close to the operating temperature of the fuel cell. In this study we have examined a range of commercial available catalysts for methanol steam reforming. The main objective is to find the $\mathrm{CO}$ content at different operating conditions in order to optimize the fuel cell performance and also to find the minimum operating temperature. The experiments are carried out using gas hourly space velocities (GHSV) of 1500 to 10000. For each GHSV the catalytic performance is examined for temperatures from $180-290^{\circ} \mathrm{C}$, giving results from low to full conversion. It is important to operate the reformer at a temperature which gives full conversion in order to use the fuel efficiently; however, if the temperature is increased above this minimum temperature for full conversion, it was found that the CO content of the reformed gas increased significantly. Depending on the GHSV the minimum temperature for full conversion is in the range of $210-290^{\circ} \mathrm{C}$ and surprisingly it was found that the CO content at this temperature is almost the same at any given flow. Apart from examination of the catalytic performance of the catalyscatalyst is oxidized and reduced, leading degradation, which needs to be taken into account. These cycles are very relevant since the final system will be exposed to numerous cycles in its lifetime. 
109 - Poster session

\title{
Control of a methanol reformer system using an adaptive neuro-fuzzy inference system approach
}

\author{
Søren Juhl Andreasen ${ }^{\mathrm{a}}$, Kristian Kjær Justesen ${ }^{\mathrm{g}}$, \\ ${ }^{a}$ Aalborg University / Department of Energy Technology (sja@et.aau.dk), ${ }^{9}$ Aalborg University / Department of Energy \\ Technology,
}

\section{Summary}

This work presents a system control strategy that uses changes in the fuel cell current to properly control the flow of hydrogen to the burner and an ANFIS modelling approach.

This work presents the experimental study and modelling of a methanol reformer system for a high temperature polymer electrolyte membrane (HTPEM) fuel cell stack. The analyzed system involved is a HTPEM fuel cell system with a controlled DC/DC converter output able to be used as e.g. a mobile $24 \mathrm{~V}$ battery charger. The advantages of using a HTPEM methanol reformer is that the high quality waste heat can be used as a system heat input to heat and evaporate the input methanol/water mixture which afterwards is catalytically converted into a hydrogen rich gas usable in the high CO tolerant HTPEM fuel cells. This creates a fuel cell system able to use a well known and easily distributable liquid fuel such as methanol; a good choice in some applications such as range extenders for electric vehicles as an alternative to compressed hydrogen. This work presents a system control strategy that uses changes in the fuel cell current to properly control the flow of hydrogen to the burner that adds heat to the reforming process. The method ensures a control strategy that avoids some of the critical events for such a system, which includes too high burner fuel flows with following critical burner temperatures, and fuel cell stack anode starvation which significantly can increase the degradation of the fuel cell stack. Modeling of the reformer dynamics is conducted using an adaptive neuro-fuzzy interference system approach (ANFIS) based on measurement results from an experimental setup. The modeling enables prediction and characterization of the important time constants of such a system. 
110 - Poster session

\title{
On The Use of Phosphoric Acid-Doped Polybenzimidazole as a Membrane in a Thermally Regenerative Fuel Cell
}

\author{
Todd Allward $^{\mathrm{a}}$, Brant Peppley ${ }^{\mathrm{b}}$, Jocelyn Zuliani ${ }^{\mathrm{c}}$, Thomas Steenberg ${ }^{\mathrm{g}}$, \\ ${ }^{\mathrm{a}}$ Fuel Cell Research Center (todd.allward@chee.queensu.ca), ${ }^{\mathrm{b}} \mathrm{Fuel}$ Cell Research Center, ${ }^{\mathrm{c}}$ Fuel Cell Research \\ Center, ${ }^{9}$ Danish Power Systems Ltd.,
}

\begin{abstract}
Phosphoric acid-doped polybenzimidazole (PBI) has been proposed as a membrane candidate for use in a novel thermally regenerative polymer electrolyte fuel cell (TRFC). The proposed system uses an external reactor to catalytically dehydrogenate 1-phenyl-1propanol, while the rehydrogenation of the resulting propiophenone is carried out in the fuel cell. Phosphoric acid-doped PBI offers general chemical stability and proton conductivity in the absence of water; these characteristics will ideally enable doped PBI membranes to function in the chemical environment of the TRFC. A test system to measure the performance of the TRFC has been constructed. Controlled flow rates of pure hydrogen and propiophenone are fed to the TRFC at a controlled temperature and the polarization characteristics and power output are measured. The suitability of phosphoric acid-doped PBI membrane for use in a TRFC was evaluated based on fuel cell polarization, impedance spectroscopy and chemical stability tests. The proton conductivity of the membrane was measured using electrochemical impedance spectroscopy (EIS). Impedance measurements of the membrane immersed in a propiophenone bath indicated that the conductivity was as high as $4.9 \mathrm{~S} / \mathrm{cm} 2$. The reason that this apparent membrane conductivity is higher than typically reported in the literature for acid-doped $\mathrm{PBI}$ may be that phosphoric acid was leached into the propiophenone bath. After exposure to the acid-doped PBI the conductivity of the propiophenone solution was significantly greater than that of the fresh propiophenone. Furthermore, the solution was coloured after impedance testing whereas the fresh propiophenone was clear. It was also observed that the membrane became brittle and discoloured after exposure to propiophenone. Further investigation of the chemical changes is in progress in order to determine whether modifications to the PBI structure to increase its chemical tolerance to the hydrogenation reaction are necessary. Preliminary fuel cell polarization results for the TRFC using standard PBI membrane electrode assemblies will be reported.
\end{abstract}




\title{
111 - Poster session
}

\section{Optimal control of PEMFC system based on Genetic Algorithm}

\author{
Sarika Tyagi ${ }^{\mathrm{a}}$, Alfredo Pérez Vega-Leal ${ }^{\mathrm{b}}$,

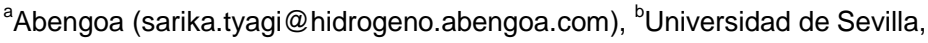

\begin{abstract}
PEM fuel cell is a non-linear dynamic energy system that transforms chemical energy to electrical energy without any carbon based emissions. Efficient maintenance of this process require an integrative control strategy, encompassing transducers (sensor and actuators) and the communication network in a flexible, optimum, adaptive and efficient manner. The final objective is to obtain the maximum available power from the system. Unfortunately, the involved variables makes it very difficult to accurately calculate the optimum current to be drawn from the stack in order to achieve this goal. In this paper we solve this optimization challenge using a Genetic Algorithm (GA) framework to efficiently control a 60 watts PEM fuel cell system. Genetic algorithms use operations inspired from Genetics and Evolution (reproduction, cross over, mutations and natural selection) to find optimum solution and variables (fitness function and fitness space). A simulation model using the GA is created and a physical experiment is conducted in order to validate the proposed model. LabVIEW programming language is used to create a second order PEMFC model. Performance of the GA is evaluated during the control of the PEMFC model. The validation of the control strategy is done using the real PEMFC under laboratory conditions. Our work underscores the importance of Global optimization techniques like GA to real world problem of control optimization of PEM fuel cell.
\end{abstract}


112 - Poster session

\title{
Development of a 100We ATR-WGS Integrated Ethanol Fuel Processor for High Temperature PEMFC Applications
}

\author{
Hyoung-Juhn Kim ${ }^{\mathrm{a}}$, Yongmin Kim ${ }^{\mathrm{g}}$, Chang Won Yoon ${ }^{\mathrm{h}}$, Suk Woo Nam ${ }^{\mathrm{i}}$,
}

${ }^{a}$ Fuel Cell Research Center, Korea Institute of Science and Technology 39-1, Hawolgok-dong, Seongbuk-gu, Seoul 136-791, Korea (hjkim25@kist.re.kr), ${ }^{9}$ Fuel Cell Research Center, Korea Institute of Science and Technology 39-1, Hawolgok-dong, Seongbuk-gu, Seoul 136-791, Korea, ${ }^{\mathrm{h}} \mathrm{Fuel}$ Cell Research Center, Korea Institute of Science and Technology 39-1, Hawolgok-dong, Seongbuk-gu, Seoul 136-791, Korea, 'Fuel Cell Research Center, Korea Institute of Science and Technology 39-1, Hawolgok-dong, Seongbuk-gu, Seoul 136-791, Korea,

While various products $\left(\mathrm{CO}, \mathrm{CO}_{2}, \mathrm{H}_{2} \mathrm{O}, \mathrm{H}_{2}\right.$ and hydrocarbons) are formed during reforming process, $\mathrm{CO}$ is detrimental to the fuel cell performance and it should be removed by $\mathrm{CO}$ clean-up units. Low temperature PEMFC (LTPEMFC) operating below $100{ }^{\circ} \mathrm{C}$ which can tolerate $\mathrm{CO}$ content in the level of 20-50 ppm needs complex fuel processor composed of an auto-thermal reforming (ATR) reactor, a two stage shift (HTS and LTS) reactor and a preferential $\mathrm{CO}$ oxidation (PROX) reactor. On the other hand, high temperature PEMFC (LTPEMFC) operating at $120^{\circ} \mathrm{C}$ or above, the reformate gas with higher CO percentage, $2 \sim 5 \%$ can be fed to the cell directly from the fuel processor. Therefore, the constitution of the fuel processor for HTPEMFC would be much simpler for LTPEMFC because the bulky PROX reactor is not required in the fuel processor. There have been few reports regarding to ethanol-fueled hydrogen generation system. Mitchell described early projections for an ethanol fuel processor based on partial oxidation. Aicher et el. worked on a PEMFC system equipped with an ethanol ATR reactor and CO clean-up units. However, the details in configuration of the reformer were not reported In this paper, we present the successful development of a 100We ethanol ATR-WGS integrated fuel processor for mobile applications based on HTPEMFC. The paper deals comprehensively with the fuel processor from the fabrication and catalytic activity tests of structured-catalysts over ATR and WGS reactions and to the design and performance evaluation of the fuel processor. The developed fuel processor possesses distinctive features such as disk-type structured catalyst for constructing radial reactors and integration of radial ATR and WGS reactors with an internal heat exchanger. 
113 - Poster session

\section{Fuel Cells for Portable Electronics}

$\underline{\text { Peter Brilner Lund }}^{\mathrm{a}}$, Jan Harry Hales ${ }^{\mathrm{a}}$, Christian Kallesøe ${ }^{\mathrm{a}}$, Henrik Fanø Clausen ${ }^{\mathrm{a}}$, Leif Højslet Christensen $^{\mathrm{a}}$,

aDanish Technological Institute, Centre for Microtechnology and Surface Analysis (pld@dti.dk),

The development of portable electronic devices has increased the demand for electric power sources with a high energy density. Examples of such devices are microelectronic devices e.g. microsensors, microengines, biomedical microsystems, microelectromechanical systems, but also smartphones, MP3 players, and GPS units. The ideal power source for these types of devices has larger volumetric energy densities than currently used batteries, as well as rechargeable capabilities. In general, the batteries used today are becoming inadequate with respect to the energy requirements for portable electronics, and fuel cells, in particular direct methanol fuel cell (DMFC), may present an alternative to batteries.

The presented research addresses the development of passive micro fuel cells. From initially developing fuel cells for hearing aids, replacing zinc-air batteries with methanol based micro fuel cells, the scope is now moving from the sub $20 \mathrm{~mW}$ range towards larger systems, with focus on pilot production of advanced fuel cell encapsulations.

In the field of catalysts for fuel cells the general goal is to provide catalytic structures capable of more efficient conversion, in order to achieve fuel cells with a greater power output, but also to minimize the use of precious metals. A general trend, also for commercial particles, is to use carbon substrates with high specific surface areas, as support for nanosized catalytic particles. We present catalyst structures fabricated using an up-scalable synthesis method with high control of both size and particle distribution onto various carbon substrates. This catalyst synthesis method is being developed towards mass production. 


\section{Author Index}

Agrawal,Bhawana, 50

Aili,David, 36, 51, 78

Akinpelu,Akeem, 94

Albérola,Nicole, 57

Alberto,Garcia-Luis, 84

Ali Atieh Hussien,Muataz, 94

Alink,Robert, 44

Allward,Todd, 125

Althues, Holger, 47

Altmann,Lena, 88

André,Johan, 57

Andreasen,Søren Juhl, 46, 124

Andreopoulou,Aikaterini, 64, 74

Anfimova,Tatiana, 75, 77, 80

Angeli,Kristina, 82

Araujo,Carla, 34

Arenz,Matthias, 88, 90, 92, 119

Arlt,Tobias, 43, 45

Assumma,Luca, 62

Baeumer,Marcus, 90

Bandlamudi,George, 104

Bang,Mads, 123

Barique,M. A., 67

Barron, Olivia, 17

Bas,Corine, 57, 118

Bassil,Joelle, 49

Bauder,Alexander, 44

Baumgärtner,Manfred, 28

Beckhaus,Peter, 104

Belabbes,Merzougui, 94, 112

Benicewicz,Brian, 23

Bernard d'Arbigny,Julien, 106

Betts, Daniel, 54

Bjerrum,Niels J., 36, 51, 75, 77, 78, 80,

93, 95, 96, 97, 105, 109, 120, 121

Bonville,Leonard J., 18, 60, 114, 115

Brooker,R. Paul, 18, 114

Bujalski,Waldemar, 42

Bujlo,Piotr, 17

Bukola,Saheed, 94

Büchi,Felix N., 56

Bäumer,Marcus, 88

Cañizares,Pablo, 100

Caque,Nicolas, 57

Cavaliere,Sara, 113

Chan,Karen, 48

Chan,Sammy Lap Ip, 42

Chandan,Amrit, 42

Chang,Hyuk, 26

Charvin,Nicolas, 57

Cheng,Xi, 39

Cho,EunAe, 91, 117

Cho,Min Kyung, 117

Choi,Kyoung Hwan, 26

Choi,SeongWoo, 26

Choi,Young-woo, 63
Chorkendorff,Ib, 98

Christensen,Erik, 51, 75, 77, 78, 79, 120

Christensen, Leif Højslet, 128

Chung,Hoon, 19

Clausen,Henrik Fanø, 128

Cleemann,Lars Nilausen, 36, 46, 77, 95, 107, 109

Colmenares, Luis, 40

Conti,Fosca, 24

Crampton,A.S., 119

Cullen,David A., 60

Daletou,Maria, 20, 64, 74

Daniel,Gonzalez, 84

De Moor,Gilles, 57

De Rycke,Thibault, 55

Dekel,Dario, 30

Diedrichs,Anja, 29

Dombrovskis,Johanna K., 38

Dong,Hanshan, 22

Donzel,Nicolas, 76, 106

Dos Santos,Leslie, 25

Doubek,Gustavo, 21

Drillet,Jean-Francois, 28

Du,Shangfeng, 22, 42

Dupont,Marc, 106

Dörfler,Susanne, 47

Eikerling,Michael, 48, 59

El Kaddouri,Assma, 118

Elsøe,Katrine, 75

Engbaek,Jakob, 123

Erne,Frank, 52

Escudero Escribano,Maria, 98

Etcheberry,Arnaud, 39

Felix,Cecil, 17, 102

Fenton,James M., 18, 60, 114, 115

Flandin,Lionel, 57, 118

Fossum,Kjell, 38

Francisco,Fernandez, 84

Friedrich,Kaspar Andreas, 44

Froning,Dieter, 43

Fujigaya,Tsuyohiko, 41

García,Hector R., 27, 100, 107, 108, 109, 110, 111

Gébel,Gérard, 25

Gogel,Viktor, 28

Goh,Jonathan, 42

Grimmer,Christoph, 86

Groß,Jennifer, 43

Grønbjerg,Ulrik, 98

Guerrero Aguinaga,Luis, 66

Guiver,Michael D., 31

Gupta,Gaurav, 85

Göran Lindbergh,Göran, 66

Hachimi,Abdouelilah, 94, 112

Hacker,Viktor, 86

Hakeem,Abbas, 94 
$3^{\text {rd }}$ CARISMA International Conference on Medium and High Temperature PEM Fuel Cells Copenhagen, 3 - 5 September 2012

Hales,Jan Harry, 128

Hampe,Manfred, 58

Hansen,Martin Kalmar, 51

Hassan,Ayaz, 89

Haußmann,Jan, 44

Heinzel,Angelika, 104

Heiz,U., 119

Henkensmeier,Dirk, 69, 91, 117

Heßke,Christian, 104

Hjuler,Hans Aage, 27, 36, 46, 107, 108, 109, 110, 111

Holdcroft,Steven, 68

Holst,Thorsten, 27, 108, 109, 110, 111

$\mathrm{Hu}$, Yang, 96

Huang, Yunjie, 77, 95, 96

Hvilsted,Søren, 68

Ingram,Andrew, 42

Ingratta,Mark, 66

Iojoiu,Cristina, 62

Jang,Jong Hyun, 91, 117

Jankova,Katja, 68

Jannasch,Patric, 35, 66, 72, 73

Jean,Bruno, 118

Jensen,Annemette Hindhede, 75,77

Jensen,Jens Oluf, 36, 51, 77, 78, 80, 93, 95, 105, 107, 109, 121

Jeong, Hu Young, 38

Jepsen,Anders, 98

Jessop,Philip, 101

Jones,Deborah, 33, 76, 82, 106, 113, 116

Jung,Hee-Suck, 103

Justesen,Kristian Kjær, 124

Kalamaras,Ioannis, 64, 74

Kallesøe,Christian, 128

Kallitsis,Joannis, 20, 64, 74

Kannan,Arunachala, 122

Kaskel,Stefan, 47

Kazdal,Johann Timur, 58

Kerres,Jochen, 28

Kim,Chang-Soo, 63

Kim,Dukjoon, 81

Kim,Hyoung-Juhn, 69, 91, 117, 127

Kim,Nam Hoon, 83

Kim,Nayoung, 70

Kim,Soo-Kil, 117

Kim,Yang-Hoon, 63

Kim,Yongmin, 127

Knudsen,Brian, 98

Korte,Carsten, 24

Kreisz,Aurelien, 76

Kreuer,Klaus-Dieter, 34

Krishnan,N. Nambi, 69

Kruusenberg,Ivar, 122

Kunz,H. Russell, 18, 114

Kwon,Sun Young, 87

Kær,Søren Knudsen, 46, 53, 99

Laberty-Robert,Christel, 25

Lang,Sebastian, 58

Langer,Matthias, 28

\section{CARISMA || \\ 2012}

Laoui,Taher, 94

Lee, Dong Hoon, 70

Lee,Hong-Ki, 103

Lee,Hye-Jin, 117

Lee,Jae-Young, 103

Lee,Joong Hee, 83

Lee, Kug-Seung, 91

Lee,Mi-Soon, 63

Lee,Moo-seok, 70

Lee,Young Moo, 31

Lehnert,Werner, 24, 43, 45, 65

Li,Qing, 19

Li,Qingfeng, 36, 51, 75, 77, 78, 79, 80, 93, 95, 96, 97, 105, 109

Li,Shenghai, 31

Lim,Tae-Hoon, 91, 117

Lin,Kejie, 22

Linardi,Marcelo, 21

Linkov, Vladimir, 102

Liu,Changpeng, 96

Liu,Fang, 65

Lobato,Justo, 100

Lund,Peter Brilner, 128

Mahlendorf,Falko, 28

Maier,Wiebke, 43, 45

Majerus,Anne, 24

Malacrida,Paolo, 98

Mamlouk,Mohamed, 99

Manke,Ingo, 43, 44, 45

Maréchal,Manuel, 25

Markötter,Henning, 44

Martin,Udo, 29

Matisen,Leonard, 122

Mayne,Martine, 39

Meier-Haack,Jochen, 28

Melchior,Jan P., 34

Melchy,Pierre-Éric, 59

Mendes,Paula M., 85

Mercier,Regis, 62

Meyer,Wolfgang H., 34

Michaelis,Alexander, 47

Mishra,Ananta Kumar, 83

Miyatake,Kenji, 32

Mohajeri,Nahid, 18, 114, 115

Morfopoulou,Christina, 64, 74

Moukheiber,Eddy, 118

Mukherjee,Sundeep, 21

Nakashima,Naotoshi, 41

Nam,Suk Woo, 69, 117, 127

Nedellec,Yannig, 106, 116

Neophytides,George, 56

Neophytides,Stylianos, 20, 64

Nesselberger,M., 119

Nicotera,Isobella, 82

Nielsen,Mads Møller, 68

Nielsen,Rasmus Munksgård, 123

Niepceron,Frédéric, 57

Nikiforov,Aleksey, 51, 120, 121

Ohira,A., 67 
$3^{\text {rd }}$ CARISMA International Conference on Medium and High Temperature PEM Fuel Cells Copenhagen, 3 - 5 September 2012

Ohira,Akihiro, 71

Orfanidi,Aline, 20

Oyarce,Alejandro, 66

Paganin, Valdecir, 89

Palmqvist,Anders E.C., 38

Pan,Chao, 51, 77

Papadimitriou,Konstantinia, 64, 74

Papageorgopoulos,Dimitrios, 16

Pardieu,Elodie, 39

Park,Hee-Young, 91

Park,Hyun-Yeol, 37, 87

Park,Jinsol, 37

Park,Jung Ock, 26

Park,Junghwa, 81

Pasupathi,Sivakumar, 17, 102

Pavlik,Tom, 54

Pearman,Benjamin P., 115

Peinecke, Volker, 28

Peppley,Brant, 101, 125

Perchthaler, Markus, 86

Pérez Vega-Leal,Alfredo, 126

Perez,Henri, 39

Permyakova,Anastasia A., 93

Perrin,Lara, 118

Perrot,Hubert, 25

Petek,Tyler, 61

Petrushina, Irina, 120, 121

Pinar,F. Javier, 100

Pinault,Mathieu, 39

Pollet,Bruno, 17, 102

Prelot,Bénédicte, 116

Rasmussen,Peder Lund, 123

Richmond,John, 42

Ridge,C. J., 119

Rodgers,Marianne, 18, 60, 114, 115

Rodrigo,Manuel, 100

Rossinot,Elisabeth, 57

Rossmeisl,Jan, 98

Roualdes,Stephanie, 49, 76

Roziere,Jacques, 76, 82, 106, 113, 116

Ruffmann,Bastian, 28

Röefzaad,M., 119

Sánches,Maria T. R., 107

Savinell,Robert, 61

Savych,Julia, 113

Sayah,Elie, 39

Schenk,Alexander, 86

Schmidt,Thomas J., 56

Schneider,Michael, 47

Scholta,Joachim, 28, 44

Schroers,Jan, 21

Schuster,Michael, 34

Schweinberger,F., 119

Schüth,Ferdi, 28

Schöppe,Günter, 28

Scott,Keith, 99

Seesukphron, Surasak, 71

Seesukphronrarak,S., 67

Sekol,Ryan, 21

\section{CARISMA I|}

Sel,Ozlem, 25

Self,Valerie, 42

Sephane,Nicolas, 106

Shah,Quratul, 122

Sharma,Surbhi, 42, 85

Sherazi,Syed Tauqir Ali, 31

Sheridan,Edel, 40

Shin, Yong Cheol, 70

Skerritt,Mark, 101

Slattery,Darlene, 18

Slattery,Darlene K., 60, 114, 115

Sohn,Joon-Yong, 31

Song,Min Young, 37, 87

Spanos,loannis, 92

Speder,Jozsef, 88

Stadlhofer,Astrid, 86

Steenberg,Thomas, 27, 36, 46, 107, 108, 109, 110, 111, 125

Stephens,Ifan, 98

Stolten,Detlef, 24, 43, 45, 65

Su,Huaneng, 17

Subianto,Surya, 113

Sung,Yung-Eun, 91

Takamuku,Shogo, 35, 72, 73

Tammeveski,Kaido, 122

Tapas,Kuila, 83

Taylor,André, 21

Terasaki,Osamu, 38

Terkelsen,Carina, 27, 36, 107, 108, 109, 110, 111

Thomassen,Magnus, 40

Ticianelli,Edson, 89

Titvinidze,Giorgi, 34

Tomas Garcia,Antonio Luis, 97, 120

Tyagi,Sarika, 126

Ubeda,Diego, 66, 100

Vang,Jakob Rabjerg, 46, 99

Vassiliev,Anton, 105

Verdaguer-Casadevall,Arnau, 98

von Barner,Jens H., 75

Wagner,Peter, 29

Wainright,Jesse, 61

Wang,Xindong, 79

Wannek,Christoph, 43, 45

Weiber,Annika, 72

Weiser,Mathias, 47

Willert-Porada,Monika, 50

Wreland Lindström,Rakel, 66

Wu,Gang, 19

Xing,Wei, 95, 96

Xu,Junyuan, 51, 79

Yang,Ami C. C., 68

Yang,Dae-Soo, 37, 87

Yang,Jingshuai, 36

Yang,Seung-Weon, 103

Yang,Tae-Hyun, 63

Yde-Andersen,Steen, 55

Yin,Min, 95

Yoo,Sung Jong, 91, 117 
$3^{\text {rd }}$ CARISMA International Conference on Medium and High Temperature PEM Fuel Cells Copenhagen, 3 - 5 September 2012

Yoon,Chang Won, 127

Yu,Jong-Sung, 37, 87

Zana,Alessandro, 90

Zaton,Marta, 116

\section{CARISMA $\|$ \\ 2012}

Zelenay,Piotr, 19

Zhang,Weibo, 104

Zhao,Xiao, 96

Zuliani,Jocelyn, 125 


\section{Carisma 2012 is sponsored by}

The Danish HotMEA consortium

\section{Hot \\ MEA}

\section{International Society of Electrochemistry}

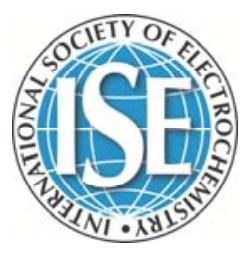

HotMEA is a ForskEl project funded by

$$
\text { ENERGINET/DIK }
$$

HotMEA partners are

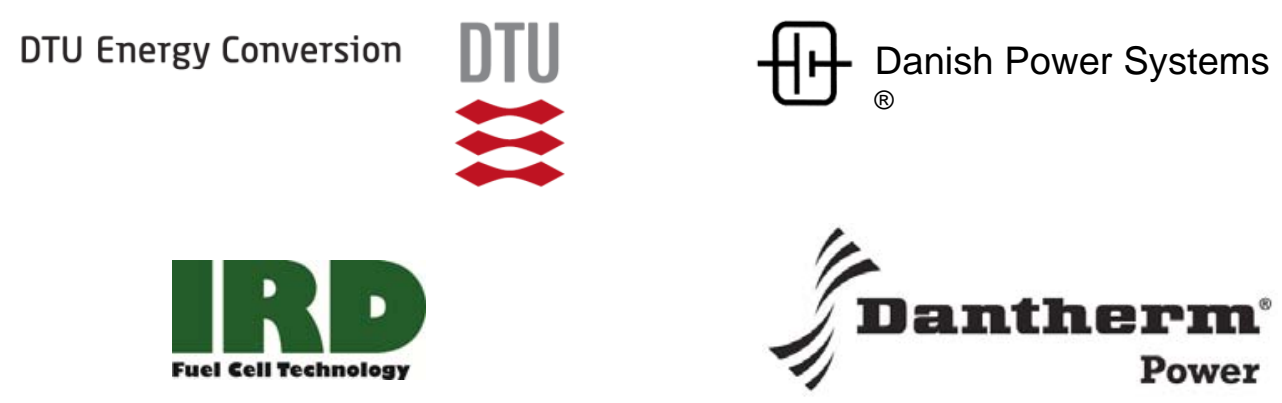

